\title{
Carboniferous chondrichthyan assemblages from the Surprise Canyon and Watahomigi formations (latest Mississippian-Early Pennsylvanian) of the western Grand Canyon, Northern Arizona
}

\author{
John-Paul M. Hodnett ${ }^{1,2}$ and David K. Elliott ${ }^{3}$ \\ ${ }^{1}$ Maryland-National Capital Parks and Planning Commission, Archaeology Program, 8204 McClure Road Upper Marlboro, MD 20772 \\ $<$ jp.hodnett@pgparks.com> \\ ${ }^{2}$ Biology Department, St. Joseph's University, 5600 City Avenue, Philadelphia, Pennsylvania 19131 USA \\ ${ }^{3}$ Geology Division, SES, Northern Arizona University, Flagstaff, Arizona 86011, USA < David.Elliott@ nau.edu>
}

\begin{abstract}
Two chondrichthyan assemblages of Late Mississippian/Early Pennsylvanian age are now recognized from the western Grand Canyon of northern Arizona. The latest Serpukhovian Surprise Canyon Formation has yielded thirtyone taxa from teeth and dermal elements, which include members of the Phoebodontiformes, Symmoriiformes, Bransonelliformes, Ctenacanthiformes, Protacrodontoidea, Hybodontiformes, Neoselachii (Anachronistidae), Paraselachii (Gregoriidae, Deeberiidae, Orodontiformes, and Eugeneodontiformes), Petalodontiformes, and Holocephali. The euselachian grade taxa are remarkably diverse with four new taxa recognized here; the Protacrodontidae: Microklomax carrieae new genus new species and Novaculodus billingsleyi new genus new species, and the Anchronistidae: Cooleyella platera new species and Amaradontus santucii new genus new species The Surprise Canyon assemblage also has the youngest occurrence of the elasmobranch Clairina, previously only known from the Upper Devonian. The Surprise Canyon Formation represents a nearshore fluvial infilling of karstic channels, followed by a shallow marine bioherm reef, and finally deeper open water deposition. The early Bashkirian Watahomigi Formation represents open marine deposition and contains only two taxa: a new xenacanthiform, Hokomata parva new genus new species, and the holocephalan Deltodus. The relationship between the Surprise Canyon and Watahomigi chondrichthyan assemblages and other significant coeval chondrichthyan assemblages suggests that there may have been eastern and western distinctions among the Euamerican assemblages during the Serpukhovian due to geographic separation by the formation of Pangea.
\end{abstract}

UUID: http://zoobank.org/54a906b6-4873-4f84-92b5-ca0752de01aa

\section{Introduction}

The diversity of marine fish during the latest Mississippian (Serpukhovian) and its subsequent transition to the Pennsylvanian (Bashkirian) is at present poorly understood. This in turn has had a major influence on what we know of fish extinction and diversification rates on a global scale (Friedman and Sallan, 2012; Sallan, 2014; Friedman, 2015). Part of our poor understanding of this transition is due to the disjunct between the better quality and better known specimens from the latest Mississippian versus the few isolated specimens collected from the Early Pennsylvanian because Carboniferous faunas are highly biased by the small number of lagerstätte, and partly also a lack of collections covering both macro and micro data from sites so that the total assemblage can be analysed. However, most of what we know from the latest Mississippian is from the Bear Gulch Limestone and Bearsden Lagerstätten localities that have produced relatively complete fish specimens (Stahl, 1999; Coates and Sequeira, 2001; Ginter et al., 2010; Lund et al., 2012, 2015). Thus, new localities and specimens are needed to help balance the data disparity for ancient fish between the Late Mississippian and the Early Pennsylvanian.

In the early 1980s, a U.S. Geological Survey of the western Grand Canyon (Billingsley and McKee, 1982) took place to help define a stratigraphic unit of Late Mississippian age within the canyon, the Surprise Canyon Formation (Billingsley and Beus, 1985). During this survey, a few macrovertebrate fossils (namely chondrichthyan teeth and spines) were collected along with bulk sediment samples for conodont assays within the Surprise Canyon Formation and the overlying Watahgomigi Formation. The macrofossils were identified and housed in the Smithsonian Paleobiology collections (R. Lund, personal communication, 2015). The conodont assay was conducted by Martin (1992), then refined by Martin and Barrick (1999), and the conodonts noted for stratigraphic provenance in the stratigraphic sections made by Billingsley and Beus (1999b). The fortuitous discovery of the remaining conodont residues from Martin's (1992) study that had been overlooked and forgotten, but containing an extensive vertebrate fauna, occurred in 2013 and the material was passed to one of us (DKE) for study. Because the localities are extremely difficult to access, there was no prospect of 
being able to visit them to collect additional samples. This forms the main part of the present study together with chondrichthyan teeth and large dermal spines originally collected by the 1980 s survey of the Surprise Canyon and Watahgomigi formations. This allows comments on their stratigraphic context and their bearing on the transition of the latest Mississippian to Early Pennsylvanian fish assemblages.

\section{Geologic setting and age}

The Surprise Canyon Formation is the name given to a series of channel fills and karstic cave deposits of Late Mississippian (Serpukhovian) age in Grand Canyon (Billingsley and Beus, 1985). These represent a considerable hiatus between the Redwall Limestone and the overlying Supai Group, which was originally recognized by McKee and Gutschick (1969) who gave several examples and descriptions of these deposits, although at that time considering them to be part of the basal Supai Group. The channels were originally described by Billingsley (1978) and later interpreted as paleo-valleys by Billingsley and McKee (1982). The formation is nowhere continuous and consists of isolated, lens-shaped outcrops scattered over Grand Canyon and Marble Canyon to the east. Outcrops are generally up to $45 \mathrm{~m}$ thick in central Grand Canyon close to the presumed headwaters of the paleochannels, but reach $122 \mathrm{~m}$ in the west in proximity to the estuary (Billingsley and Beus, 1985). Description of the extensive fossil invertebrate assemblages was carried out by Beus $(1985,1986,1999)$, who showed that the lower beds are fluvial while the upper part of the succession is marine.

The Surprise Canyon Formation was originally divided into a lower unit consisting of fluvial clastics and an upper marine unit composed of siltstones and limestones (Billingsley and Beus, 1985). Subsequent studies indicated the presence of three units: a lower fluvial chert pebble conglomerate interbedded with coarse- to fine-grained, red-brown sandstone and siltstone mainly of terrestrial origin; a middle marine unit of gray-yellow or reddish-brown, coarsely crystalline, thin-bedded limestone separated from the lower unit by an erosional unconformity; and an upper marine unit of reddish-brown, calcareous siltstone, with minor limestone. Some of the lower fluvial rocks in western Grand Canyon include interbedded limestone and shale, suggesting brief marine incursions into paleoriver drainages (Billingsley and Beus, 1999a).

The sequence in the paleovalley fills is interpreted as representing deposition in channels developed in the Redwall Limestone. These were shallow deltaic and tidal drainage channels formed during the westward retreat of the sea in which the Redwall Limestone had accumulated. Development of karst and entrenchment of the channels probably occurred in late Meramecian or early Chesterian times (Billingsley and Beus, 1999a) and led to the development of a network of drainages. Highlands to the east became a source area for detrital material that was incorporated into deposits of the Surprise Canyon Formation. In the late Chesterian/Serpukhovian a period of subsidence allowed marine waters to gradually flood the eroded valleys forming local estuaries (Billingsley and Beus, 1999a). As the sea transgressed, the estuaries also moved eastwards, their deposits forming the marine middle and upper units of the Surprise Canyon Formation. A minor unconformity between the Surprise Canyon
Formation and the overlying Watahomigi Formation (the basal formation of the Supai Group) suggests a regional interval of uplift and erosion (Billingsley and Beus, 1999a).

The initial age determination of the Redwall and Watahomigi formations was based on calcareous foraminifera (Skipp, 1969) and corals (Sando, 1969). Based on these studies, the youngest Redwall strata were thought to be Osagean or early Meramecian and the lowest Watahomigi beds were thought to be Middle Pennsylvanian. This meant that the erosional unconformity between them represented the Late Mississippian and the Early Pennsylvanian. The subsequent discovery of an erosional remnant of Redwall containing late Meramecian or early Chesterian foraminifera and corals (Skipp, 1969; Sando, 1969) reduced the gap between the Redwall and the Watahomigi formations to the Chesterian and part of the Morowan. This gap was further narrowed by the determination of a mid-Morrowan (Bashkirian) age for the lowermost units of the Watahomigi Formation based on brachiopods (Gordon, 1982).

Conodonts were first used to determine an age for the Redwall Limestone and these indicated that in east-central Arizona the youngest Redwall strata were late Meramecian in age (Racey, 1974). Later work by Grover (1989) recovered conodonts from several limestones within the Surprise Canyon Formation and demonstrated the presence of the late Chesterian unicornis zone and the Early Pennsylvanian primus zone, suggesting that the Mississippian-Pennsylvanian boundary was encompassed by the Surprise Canyon Formation. A conodont study was undertaken to verify dates through the Surprise Canyon Formation and into the Watahomigi Formation (Martin and Barrick, 1999). Based on a sparse, low-diversity conodont fauna, Martin and Barrick (1999) determined that the Surprise Canyon Formation is latest Chesterian (Late Mississippian) in age and that the Mississippian-Pennsylvanian boundary occurs in the lower part of the Watahomigi Formation, $17 \mathrm{~m}$ above the Surprise Canyon-Watahomigi contact. These determinations are supported by the invertebrate, palynomorph, and foraminiferal data (Beus and Martin, 1999). Although 'shark teeth' were noted in the residues from several of the localities (Martin and Barrick, 1999), no attempt was made to have these identified. Dermal denticles are also present in these residues, but are not dealt with here.

Localities. - At present eight localities within the Grand Canyon have produced identifiable vertebrate fossils from the Surprise Canyon and Watahomigi formations (Fig. 1). However, of these eight localities, only four show significant fish assemblages from the transitional lower/middle, middle, and upper members of the Surprise Canyon Formation and the lower member of the Watahomigi Formation, while the other localities had a few taxa respectively (Fig. 2). Precise coordinates for the localities are on file at the Museum of Northern Arizona.

Surprise Canyon Formation, lower member.-The majority of shark fossils collected from the lower member of the Surprise Canyon Formation consist of large isolated dental and dermal elements in fluvial or estuary deposits, with lack of abrasion suggesting that they had not been significantly transported. Isolated cochliodont tooth plates were collected from unit 6 


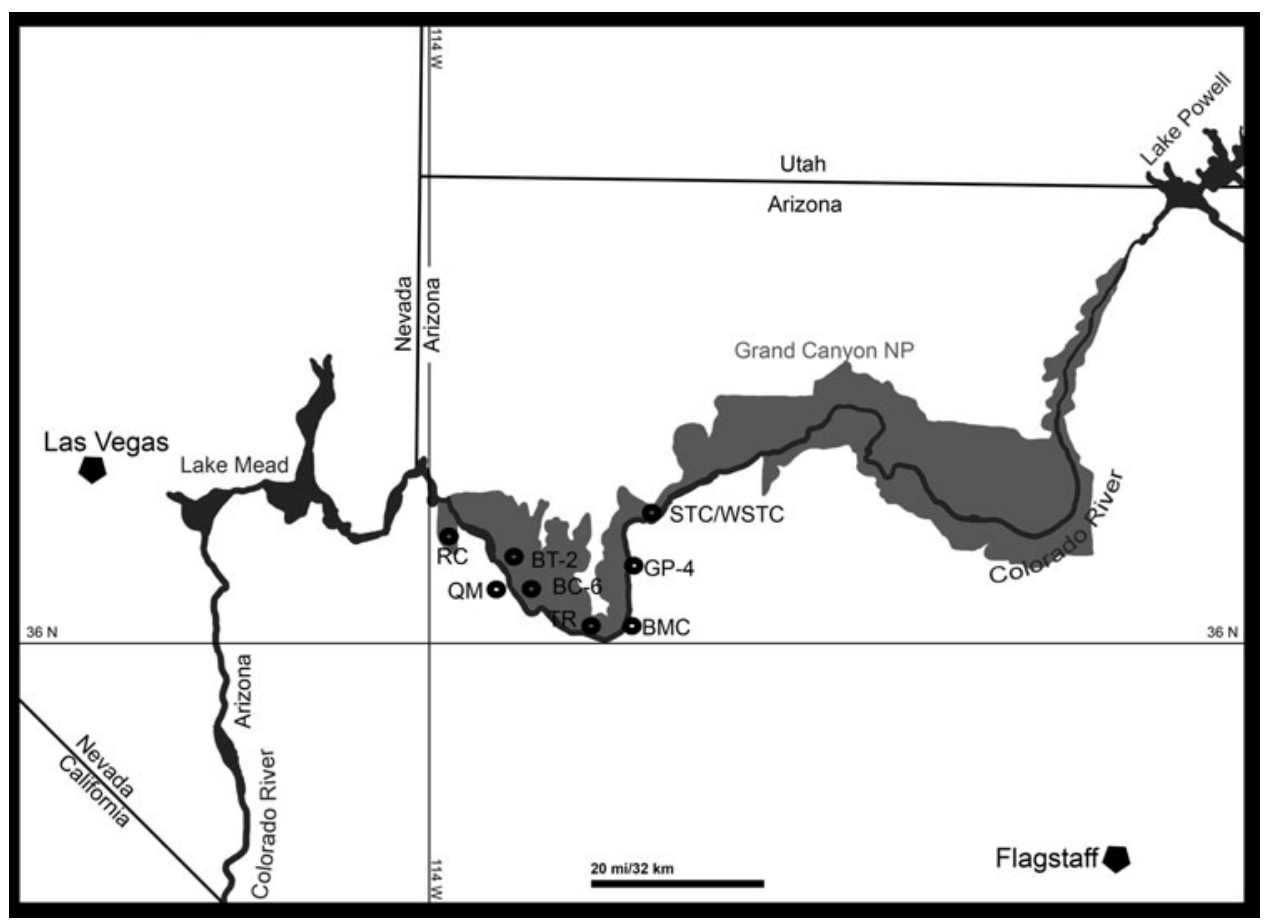

Figure 1. Map of the sampled localities within the Grand Canyon National Park. BC-6, Burnt Springs Canyon section 6; BMC, Blue Mountain Canyon locality; BT-2, Bat Tower locality 2; GP-4, Granite Park section 4; QM, Quartermaster Canyon locality; RC, Rampart Cave Section; STC/WSTC, Stairway Canyon/Western Stairway Canyon; TR, Travertine Canyon locality; (Billingsley and Beus, 1999b).

of the Rampart Cave (RC) section of the western Grand Canyon, which is a thin-bedded, yellowish-orange and grayish-green siltstone and sandstone that contained crossbedding, ripple marks, and abundant plant fragments and carbonized wood (Billingsley and Beus, 1999b). The Rampart Cave Canyon paleovalley had a width of $396 \mathrm{~m}$ and a depth of $51.2 \mathrm{~m}$ (Billingsley and Beus, 1999b). A single isolated fragmentary fin spine was collected from unit 4 of Quartermaster Canyon (QM) locality 2 section in the western Grand Canyon, from a dark purplish-brown, medium- to coarse-grained sandstone and light-gray, thin-bedded, siltstone, which was noted for numerous bone fragments (Billingsley and Beus, 1999b). The Quartermaster Canyon paleovalley had an estimated width of $\sim 305 \mathrm{~m}$ and a depth of $60.4 \mathrm{~m}$ (Billingsley and Beus, 1999b). A single cochliodont dental plate was collected from unit 1 of the Travertine Canyon (TR) section of the western Grand Canyon, which consists of sandstone and conglomerate of angular white and gray chert pebbles, in dark reddish-brown to black, mediumto very coarse-grained sandstone that was noted for large vertebrate bone fragments (Billingsley et al., 1999; Billingsley and Beus, 1999b). The Travertine Canyon paleovalley has an estimated width of $92 \mathrm{~m}$ and a depth of $25.5 \mathrm{~m}$ (Billingsley and Beus, 1999b). A cochliodont dental plate and isolated fin spine were collected from the Granite Park Wash (GP-4) section 5, which is a massive conglomerate bed composed of subrounded red chert pebbles in a dark-gray limestone that also contained solitary corals and spiriferid brachiopods (Billingsley and Beus, 1999b). The Granite Park paleovalley is estimated to be $350 \mathrm{~m}$ wide and 64.9-68.9 m deep (Billingsley and Beus, 1999b).
Surprise Canyon Formation, transitional lower/middle member.-A small but diverse assemblage of microvertebrate fossils was collected from conodont residues from the Burnt Springs Canyon (BC) locality from section 10, which is a calcareous light orange-brown, fine- to medium-grained, thinly laminated to thin-bedded sandstone that was treated by Billingsley and Beus (1999b) as the lowermost section of the middle member. However, the lithology is also similar to some of the upper sections of the lower member elsewhere in the Surprise Canyon Formation and may represent either the uppermost lower member or the lowermost middle member of the Surprise Canyon Formation. The paleovalley of this section of the Burnt Springs Canyon is estimated to be $425 \mathrm{~m}$ wide and $89.2 \mathrm{~m}$ deep (Billingsley and Beus, 1999b).

Surprise Canyon Formation, middle member.-The majority of the diversity seen in the sharks from the Surprise Canyon Formation occurs in the middle member. Bat Tower Overlook (BT-2) is the type section for the Surprise Canyon Formation and a diverse microvertebrate assemblage was collected from sections 5 and 6 of the middle member from conodont residues. Section 5 of the type section consists of a thinly bedded, dark reddish-brown to yellowish-gray marine limestone with brachiopods, small gastropods, crinoids, and abundant shell fragments (Billingsley and Beus, 1999b). Section 6 consists of a thin dark purplish-gray limestone with separations of thin silty limesone beds and contains brachiopods (Billingsely and Beus, 1999). The paleovalley at this section of the Bat Tower Overlook is estimated to be $305 \mathrm{~m}$ wide and $91.1 \mathrm{~m}$ deep.

A diverse micro-vertebrate assemblage was collected from conodont residues from the Blue Mountain Canyon 

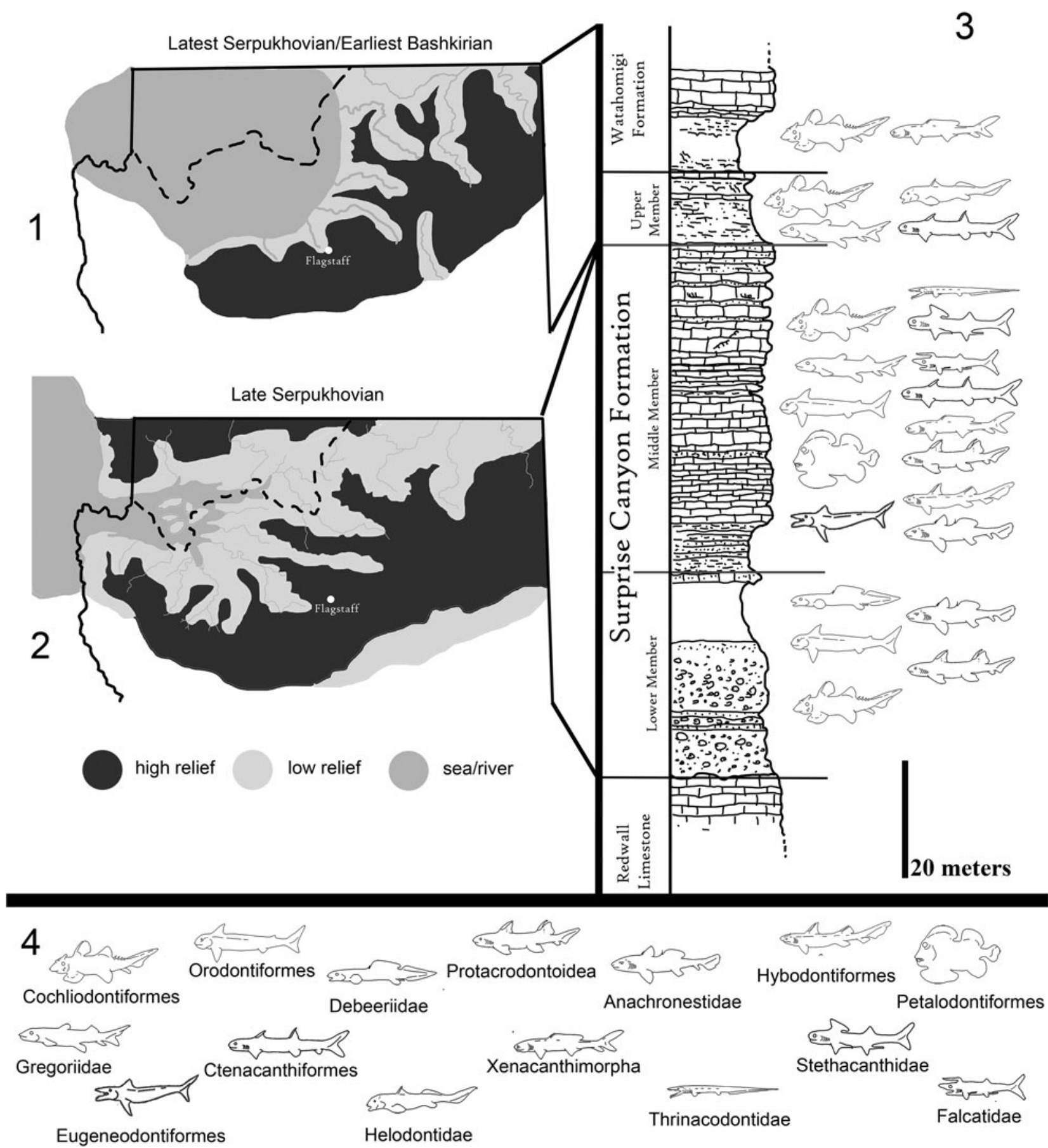

Figure 2. Paleogeographic maps of the Serpukhovian and Bashkirian of the Grand Canyon and generalized stratigraphic distribution of chondrichthyan taxa within the Surprise Canyon and Watahomigi formations. (1) Paleogeographic map of the open marine phase of the upper member of the Surprise Canyon Formation and the lower Watahomigi Formation; (2) paleogeographic map of the shallow marine and estuarine phase of the lower and middle members of the Surprise Canyon Formation; (3) type section, Bat Tower locality 2, showing the general distribution of chondrichthyan taxa within the Surprise Canyon and Watahomigi formations; (4) the major chondrichthyan taxonomic groups presented in this study.

(BMC) section 3 and section 4 from the top of unit 2. Unit 2 consists of a medium yellowish-gray skeletal limestone with abundant brachiopods near the base (Billingsley and Beus, 1999b). The Blue Mountain Canyon paleovalley is estimated to be $140 \mathrm{~m}$ wide with a depth of $22-47.9 \mathrm{~m}$ (Billingsley and Beus, 1999b). Macro-vertebrate fossils were collected from unit 3 of the West Stairway Canyon section (WSTC), which consists of a conglomerate of pale-red to yellow chert pebbles in a light yellowish-gray limestone matrix with brachiopods and crinoid plates (Billingsley and Beus, 1999b). The paleovalley at West Stairway Canyon is estimated to be $140 \mathrm{~m}$ wide and $19.5 \mathrm{~m}$ deep. The West Stairway Canyon section is presently the most easterly locality of the middle member of the Surprise Canyon Formation to produce vertebrate fossils within the Grand Canyon. 
Surprise Canyon Formation, upper member.-Vertebrate fossils from the upper member are primarily known from isolated macro-vertebrates, with the exception of a small assemblage from the Bat Tower 2 type section. This assemblage was collected from unit 7 of the Bat Tower 2 type section, which consists of a red shale or siltstone and gray limestone beds. The Stairway Canyon (STC) section has produced macro-vertebrate fossils from two units within the upper member. Unit 3 produced a few cochliodont dental plates and marks the lowest unit within the upper member at Stairway Canyon, which consists of a dark reddish-brown to purple mudstone with brachiopod, coral, and bryozoan debris. A single large cladodont tooth was collected from unit 5 of the Stairway Canyon section, which consists of a medium-gray sandy to silty limestone and pale red siltstone. The paleovalley at Stairway Canyon is estimated to be $122 \mathrm{~m}$ wide and $39 \mathrm{~m}$ deep (Billingsley and Beus, 1999b). Both unit 3 and unit 5 of the Stairway Canyon section mark the easternmost vertebrate localities within the upper member of the Surprise Canyon Formation in the Grand Canyon.

Watahomigi Formation.-The fossils decribed here were collected primarily from the lower Watahomigi Formation of the western Grand Canyon. A small microvertebrate assemblage is identified from Quartermaster Canyon (QM) in unit 12 of section 4 , which consists of lavender to purplishgray limestone and shale (Martin, 1992). An isolated cochliodont tooth was collected from the lower Watahomigi Formation, "10 meters above the Surprise Canyon Formation" from an undisclosed locality close to Three Springs Canyon in the western Grand Canyon by George Billingsley in 1984 (Smithsonian Paleobiology records). At this phase of the transgression, all paleovalleys were filled.

\section{Materials and methods}

All samples were collected as part of the initial surveys of the Surprise Canyon and Watahomigi formations (Martin, 1992; Billingsley and Beus, 1999a). The macrofossils were mechanically prepared in some cases, and all specimens were photographed after coating with ammonium chloride. Microfossils were collected from conodont residues that were processed by crushing bulk samples and then breaking them down with acetic acid and screening the residue (see Martin, 1992 for details of methods used). Microfossils were illustrated using SEM imagery at the Northern Arizona University Imaging and Histology Core Facility using a Zeiss Supra 40VP field emission scanning electron microscope. Because acid etching caused extreme fragility, some specimens were illustrated in a limited number of views.

Repositories and institutional abbreviations.-AMNH, American Museum of Natural History, New York; BGS, British Geological Survey, Keyworth, England; BYU, Bringham Young University, Provo, UT; CM, Carnegie Museum of Natural History, Section of Vertebrate Paleontology, Pittsburgh, PA; IGPUW, Institute of Geology, University of Warsaw, Poland; KUVP, University of Kansas
Vertebrate Paleontology Collection, Lawrence, KS; MCZ, Harvard University Museum of Comparative Zoology, Cambridge, MA; MNA, Museum of Northern Arizona, Flagstaff, AZ; MV, University of Montana Vertebrate Collections, Missoula, MT; NHM-P, Natural History Museum, London; TMM, Texas Memorial Museum, Austin, TX; USNM PAL, Department of Paleobiology, Smithsonian Institution, National Museum of Natural History, Washington, DC; ZPAL, Institute of Palaeobiology, Polish Academy of Sciences, Warsaw, Poland.

\section{Systematic paleontology}

Class Chondrichthyes Huxley, 1880

Subclass Elasmobranchii Bonaparte, 1838

Order Phoebodontiformes Ginter, Hairapetian, and Klug, 2002 Family Thrinacodontidae Grogan and Lund, 2008 Genus Thrinacodus St. John and Worthen, 1875

Thrinacodus gracia Grogan and Lund, 2008 Figure 3

Holotype.-Complete female specimen (CM 62724) from Bear Gulch Limestone lens, Bear Gulch Member of the Heath Formation, SW of Becket, Fergus County, Montana, USA.

Occurrence.-Surprise Canyon Formation; middle member; latest Mississippian (Serpukhovian); Bat Tower 2, sections 13 and 15; Blue Mountain Canyon locality 4, section 2; Blue Mountain Canyon locality 84-9, section 3.

Description.-Six small tricuspid teeth, in various degrees of preservation. The distal cusp is larger than the median and lateral cusps. The median cusp is positioned near the labial border of the tooth. The labial surfaces of the cusps are smooth with coarse cristae ornamenting the lingual surface. Orientation of the cusp row varies from being nearly in line to slightly angled mesially. The lingual torsus of the tooth base is broad mesiodistally and moderately elongated lingually. The

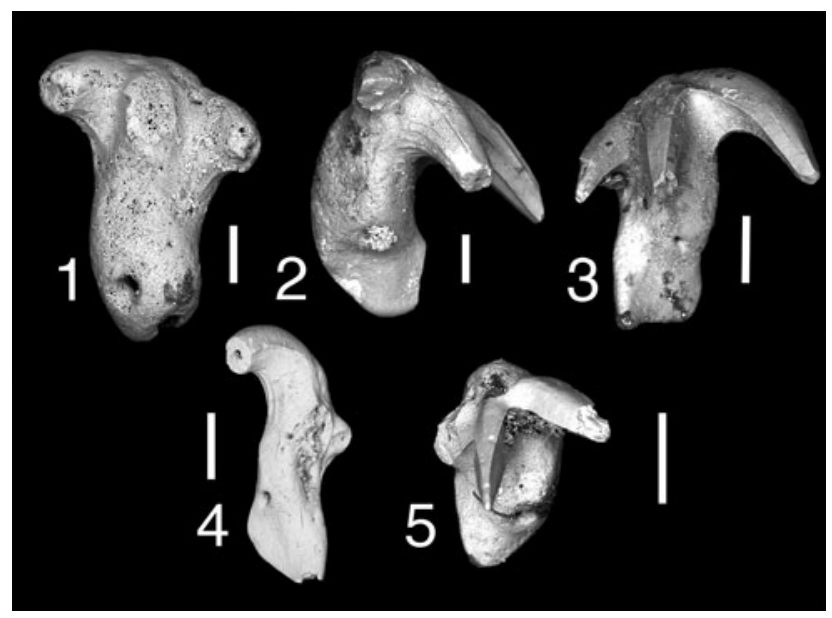

Figure 3. Teeth of Thrinacodus gracia. (1) MNA V11260, tooth in occlusal view; (2) MNA V11256, tooth in oblique labial view; (3) MNA V11255; (4) MNA V11261, tooth in occlusal view; (5) MNA V11254, tooth in occlusal view. Scale bars $=200 \mu \mathrm{m}$. 
lingual torsus is bulbous, tall, and not flattened. A large lingual foramen is present, just adjacent to the midline of the tooth.

Material.-MNA V11254, MNA V11255, MNA V11256, MNA V11257, MNA V11258, MNA V11259, MNA V11260, MNA V11261.

Remarks. - The majority of the thrinacodont teeth are of the morphology seen in the eel-like chondrichthyan Thrinacodus gracia. Teeth of $T$. gracia are characterized by conical cusps with coarse cristae on the lingual margin, which are moderately distally displaced with the mesial cusp the largest (Grogan and Lund, 2008; Ginter et al., 2010). The lingual torsus in $T$. gracia is not oro-aborally flattened and spatulate in form, but relatively thick and bulbous (Grogan and Lund, 2008; Ginter and Turner, 2010). The taxonomic nomenclature for $T$. gracia has been the subject of much debate because previous work on thrinacodont dentitions was based primarily on isolated teeth and $T$. gracia is the only species known from multiple complete endoskeletons (Turner, 1983; Long, 1990; Duncan, 2003; Grogan and Lund, 2008; Ginter et al., 2010; Ginter and Turner, 2010).

Two teeth, MNA V11254 and MNA V11261 (Fig. 3.2, 3.5), have some resemblance to other thrinacodont taxa. MNA V11254 is similar to Thrinacodus dziki Ginter et al., 2015 based on the lingual placement of the median cusp and the presence of a labial bulge with a labial foramen (Fig. 3.5; Ginter et al., 2015). However, the Surprise Canyon Formation specimen differs from the type specimens in having overall a more robust and shorter lingual torsus than in the type material from the Visean of northern Europe (Ginter et al., 2015; Smith et al., 2017), which is more lingually elongated and slender mesiodistally. MNA V11261 is similar to Thrinacodus ferox Turner, 1982. This specimen is the only example of a thrinacodont tooth with an enlarged distal cusp and reduced median and mesial cusps from the Surprise Canyon samples (Fig. 3.4). Turner (1982) first described thrinacodont teeth with these features from the Late Devonian of Australia. She placed them in a new taxon Harpago ferox, which was later designated Harpagodens ferox because the previous genus name was preoccupied (Turner, 1983). Later, it was determined that this taxon should be placed in the preexisting Thrinacodus (St. John and Worthen, 1875) as T. ferox (Long, 1990). Thrinacodus ferox is presently the only thrinacodont taxon to have the feature of an enlarged and recurved distal cusp with the medial and mesial cusps reduced in size on the lateral teeth (Ginter and Turner, 2010; Ginter et al., 2010). These two specimens are most likely rare variants belonging to a single species, $T$. gracia, within the Surprise Canyon assemblage.

Superorder Xenacanthimorpha Nelson, 1976

Order Bransonelliformes Hampe and Ivanov, 2007

Genus Bransonella Harlton, 1933

Bransonella nebraskensis Johnson, 1984

Figure 4.1-4.4

Holotype.-Tooth (TMM 41647-328) from Peru locality, Sites 2 and 3, south of Peru, Nemaha County Nebraska, USA.

Occurrence.-Surprise Canyon Formation; middle member; latest Mississippian (Serpukhovian); Blue Mountain Canyon locality 3, section 2; Blue Mountain Canyon locality 4, section 2 .

Description.-Two small tricuspid teeth with broken cusps and complete tooth bases. The cusps are mostly broken, with MNA V11262 (Fig. 4.1, 4.2) having a worn median cusp still present. The lateral cusps have larger diameters than the median cusp with large pulp cavities. The labial surface of MNA V11263 (Fig. 4.3) shows a series of cristae were present. The basolabial projection is mesiodistally broad and slightly recurved aborally. Two labial foramina are present on either side of the basolabial projection. The oral-lingual button is ovate in shape, broad mesiodistally, and does not merge with the lingual margin of the tooth. A large foramen is present on the lingual margin of the oral-lingual button.

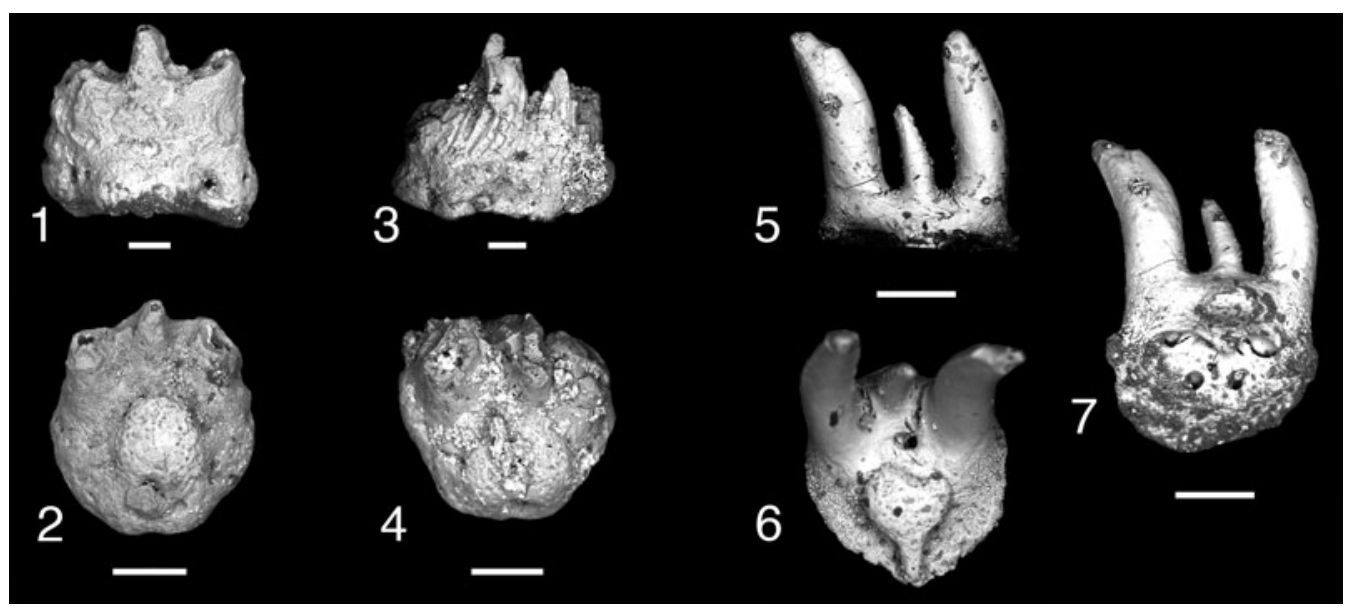

Figure 4. Teeth of Xenacanthomorpha. (1-4) Bransonella nebraskensis; (1, 2) MNA V11262, (1) labial view, (2) occlusal view; (3, 4) MNA V11263, (3) labial view, (4) occlusal view. (5-7) Hokomata parva n. gen. n. sp., MNA V11264, holotype, (5) labial view, (6) occlusal view, (7) oblique aboral view. Scale bars = $200 \mu \mathrm{m}$. 


\section{Material.-MNA V11262, MNA V11263.}

Remarks.-Bransonella is known from four species and ranges from the Middle Mississippian to the middle Permian worldwide (Elliott and Hodnett, 2013). Of these four, $B$. lingulata Ivanov and Ginter, 1996 and B. nebraskensis occur in the latest Mississippian. Although the Surprise Canyon specimens are fragmentary, features of the orolingual button identify which species of Bransonella they belong to. In $B$. lingulata the lingual margin of the orolingual button is merged with the lingual rim of the tooth base (Ivanov and Ginter, 1996). In B. nebraskensis the orolingual button is forward of the lingual rim and has a basal canal between the orolingual button and the lingual rim (Johnson, 1984; Ivanov and Ginter, 1996). The orolingual button in the Surprise Canyon specimens does not merge with the lingual rim and has a basal canal between the orolingual button and the lingual rim, indicating that they are B. nebraskensis.

Order Xenacanthiformes Berg, 1937

Family Diplodoselachidae Dick, 1981

Genus Hokomata new genus

Type species.—Hokomata parva n. gen. n. sp.

Diagnosis.—As for species, by monotypy.

Etymology.-Hokomata (Yuman dialect), a mischievous Hualapai and Havasupai tribal deity who brought forth a great flood that would eventually carve the Grand Canyon.

Remarks._-See remarks for species.

Hokomata parva new species

Figure 4.5-4.7

Holotype.-MNA V11264.

Diagnosis._A small diplodoselachian xenacanth with tall, near erect cusps. All cusps are smooth, lacking verticle cristae, with a slight mesial incline. Lateral and distal cusps labiolingually compressed with un-serrated carina. Median cusp evenly spaced from the lateral cusps, labiolingually rounded, and half the height of the lateral and distal cusps. Tooth base ovate; oral-aborally compressed, orolingual button near circular with a lingual shaft. Basolabial projection small and elliptical. Kidney-shaped aboral depression with four large foramina.

Occurrence.-Watahomigi Formation; lower member; Early Pennsylvanian (Bashkirian); Quartermaster Canyon, locality 4, section 9.

Description.-Single complete tricuspid tooth $\sim 500 \mu \mathrm{m}$ wide mesiodistally, $550 \mu \mathrm{m}$ long labiolingually, and $500 \mu \mathrm{m}$ in height (Fig. 4.5-4.7). Cusps elongated, nearly erect, with slight mesial orientation. Median cusp about half the height of distal and lateral cusps, which are labiolingually compressed with a smooth carina on mesiodistal margins of crown. Surface of cusps is smooth and lacks verticle cristae. The tooth base is approximately ovate and oral-aborally compressed. The tooth base is longer labiolingually than mesiodistally. A median foramen is present on the oral surface between the lingual side of the median cusp and the labial border of the orolingual button (Fig. 4.6). The orolingual button is near the center of the tooth base with a narrow lingually projecting shaft that terminates at the midline of the lingual margin. A few small foramina are present along the mesiodistal margins of this shaft. The orolingual button and the mesiodistal margins of the tooth base have a fine sponge-like texture. The basolabial projection is mesiodistally narrow and elliptical in shape with a small lingually directed wedge-like projection. A well-defined kidney-shaped depression is present medially on the aboral surface between the lingual margin of the basolabial projection and a third of the distance from the lingual margin. Four large foramina are present on the mesiodistal margins of this aboral depression, with the most labially positioned foramen being the largest.

Etymology.-Latin parva, little.

Remarks.-Hokomata parva n. gen. n. sp. posesses characters common to three other xenacanth genera: Orthacanthus, Triodus, and Hagenoselache. All three taxa are known from nearly complete specimens and occur in the Early Pennsylvanian (Bashkirian) of Europe and North America. Johnson and Thayer (2009) described the teeth of two xenacanth taxa, Orthacanthus donnelljohnsi Johnson and Thayer, 2009 and Triodus elpia Johnson and Thayer, 2009, from the Black Prince Limestone (Bashkirian) in the Swisshelm Mountains of southern Arizona. Additional Early Pennsylvanian Orthacanthus and Triodus taxa include $O$. gibbosus Binney, 1841 and T. serratus Davis, 1892 from England (Ginter et al., 2010). Hagenoselache sippeli Hampe and Heidtke, 1997 is known from a single nearly complete individual from the Serpukovian/Bashkirian Hagen-Vorhalle of Germany (Hampe and Heidtke, 1997; Ginter et al., 2010).

The lateral cusps of Hokomata parva n. gen. n. sp. are similar to those in Triodus and Hagenoselache in having a near-erect orientation. In Orthacanthus, the lateral cusps, particularly the mesially positioned cusp, angle away from the median cusp. The lateral cusps of $H$. parva differ from Triodus and Hagenoselache in being labiolingually compressed and lacking cristae on the distal tips. The lateral cusps of Orthacanthus are also labiolingually compressed, but those of $H$. parva differ in being less expanded mesiodistally and lacking serrations on the carina. The median cusp in Orthacanthus is labiolingually compressed and is positioned forward of and close to the lateral cusps. In H. parva n. gen. n. sp., Triodus, and Hagenoselache the median cusp is labiolingually rounded, but in $H$. parva it lacks distal cristae. There is a well-developed gap between the lateral cusps and the median cusp, and they are all nearly in line in $H$. parva n. gen. n. sp. In Triodus, the median cusp is positioned just forward of the lateral cusps with only a slight gap between the cusps. The median cusp in Hagenoselache is rounded (Hampe and Heidtke, 1997) and seems to be positioned nearly in line with the lateral cusps (Hampe and Heidtke, 1997; Fig. 4) but this is difficult to discern from the illustrations. 
The tooth base of Hokomata parva n. gen. n. sp. is more oral-aborally compressed than in Triodus, Hagenoselache, and Orthacanthus. In H. parva, the mesiodistal width is proportionally broader than in Triodus and Hagenoselache, and it is also less elongated labiolingually, similar to the proportions seen in Orthacanthus. The orolingual button has a lingually directed shaft, a feature that is also seen in Triodus, Orthacanthus, and on some of the teeth of Hagenoselache (Hampe and Heidtke, 1997; Ginter et al., 2010). The mesiodistal width of the basolabial projection in $H$. parva n. gen. n. sp. is narrower and not as broad mesiodistally as in Triodus. The basolabial projection has a small lingually oriented wedge-shaped projection, which is similar to that seen in Orthacanthus and Hagenoselache. There is a single median nutrient foramen orally between the median cusp and the orolingual button, a feature seen in Hagenoselache and some teeth of Triodus and Orthacanthus (Ginter et al., 2010). A few small nutrient foramina also occur along the lingual shaft of the orolingual button in H. parva, which is similar to the condition seen in Triodus and Orthacanthus (Johnson and Thayer, 2009; Ginter et al., 2010). On the aboral surface of the tooth base in $H$. parva n. gen. n. sp., four large nutrient foramina are present, while Triodus and Orthacanthus typically have no more than two or three prominent foramina, with some smaller foramina (Ginter et al., 2010). Hagenoselache can have up to seven nutrient foramina on the aboral surface of the tooth base (Ginter et al., 2010).
Most xenacanths, excluding Bransonella, were associated with brackish and fresh water environments during the Mississippian/Pennsylvanian transition (Ginter et al., 2010). The oldest xenacanthids are Diplodoselache woodi Dick, 1981 from the Visean of the Oil Shale groups of Scotland, which comes from a lagoonal deposit that had both marine and brackish influences (Dick, 1981), and Reginaselache morrisi Turner and Burrow, 2011 from the mid-Visean Ducabrook Formation of central Queensland, which comes from estuarine deposits (Turner and Burrow, 2011). Bransonella itself is primarily known from marine environments (Ivanov and Ginter, 1996; Elliott and Hodnett, 2013), but was also recovered from the estuarine Lower Pennsylvanian Black Prince Limestone in the Swisshelm Mountains in Southern Arizona, together with the xenacanths Triodus and Orthacanthus and lepospondyl amphibians (Thayer, 1985; Johnson and Thayer, 2009). The Watahomigi Formation has no indication of brackish or fresh water influences and so we consider Hokomata parva n. gen. n. sp. to be a marine xenacanth.

Order Symmoriiformes Zangerl, 1981

Family Stethacanthidae Lund, 1974

Stethacanthid indeterminate Figure 5.1-5.9

Occurrence.-Surprise Canyon Formation; middle member; latest Mississippian (Serpukhovian); Bat Tower 2, section 13;

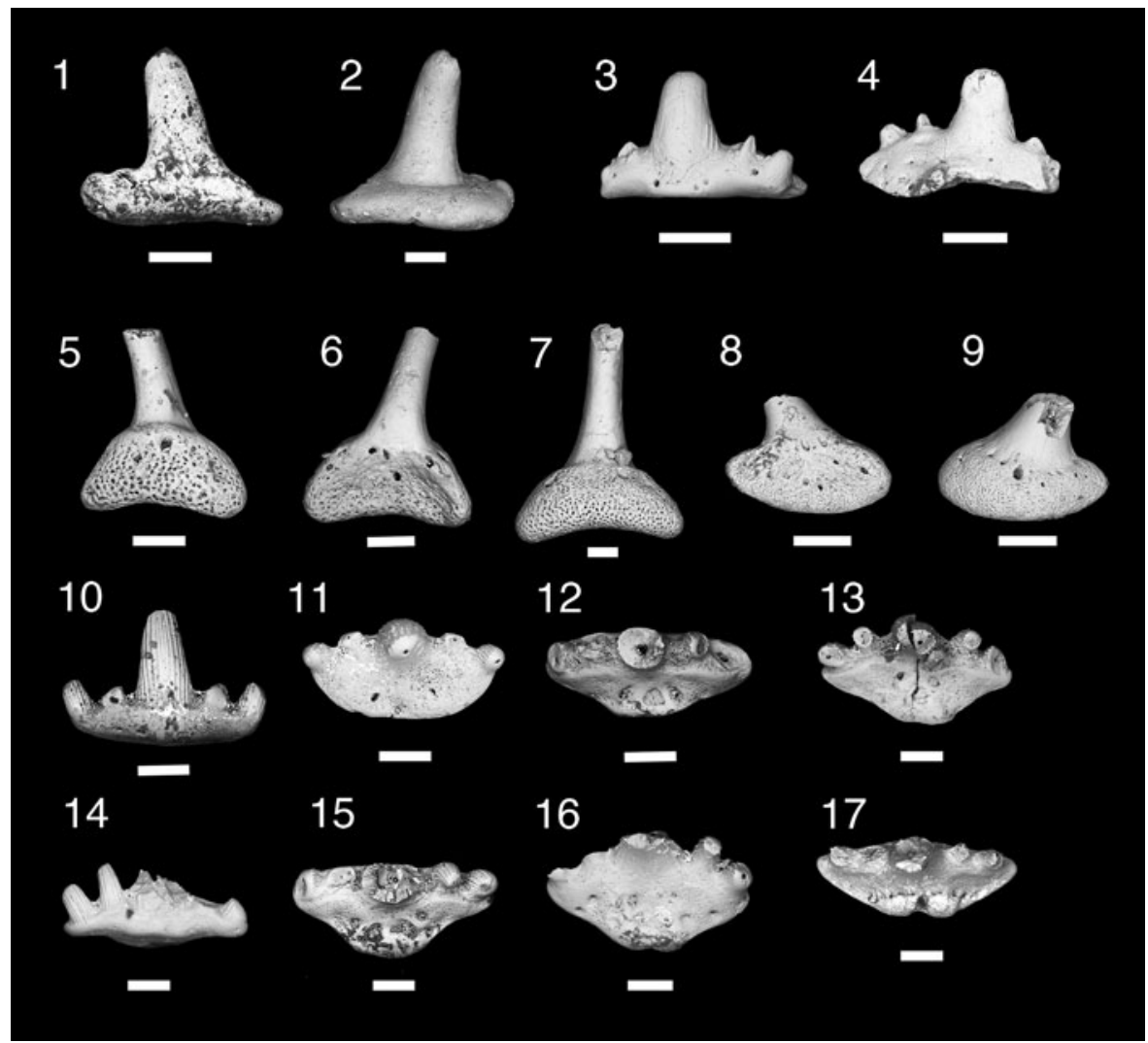

Figure 5. Teeth and denticles of Symmoriiformes. (1-9) Stethacanthid indeterminate; $(\mathbf{1}, \mathbf{2})$ MNA V11265, tooth, (1) labial view, (2) lingual view; (3, 4) MNA V11266, tooth, (3) labial view, (4) lingual view; $(\mathbf{5 , 6})$ MNA V11268, denticle, (5) anterior view, (6) posterior view; (7) MNA V11267, denticle, posterior view; $(\mathbf{8 , 9})$ MNA V11269, denticle (8) anterior, (9) posterior. (10-16) Falcatid indeterminate 1; (10, 11) MNA V11270, (10) labial view, (11) occlusal view; (12) MNA V11272, occlusal view; (13) MNA V11274, occlusal view; (14, 15) MNA V11271, (14) labial view, (15) occlusal view; (16) MNA 11273, occlusal view. (17) Falcatid indeterminate 2, MNA V11275 occlusal view. Scale bars $=200 \mu \mathrm{m}$. 
Blue Mountain Canyon locality 3, section 2 and 3; Blue Mountain Canyon locality 4, section 2.

Description.-Two small worn cladodont teeth (Fig. 5.1-5.4) and three denticles (Fig. 5.5-5.9). Teeth are $\sim 600 \mu \mathrm{m}$ wide mesiodistally, median cusp tall, narrow, and circular in cross section. Lateral and intermediate denticles worn, but were small relative to median cusp. Surfaces of cusps are smooth in MNA V11265 (Fig. 5.1, 5.2), possibly due to abrasion. MNA V11266 (Fig. 5.3, 5.4) shows coarse cristae on lateral surface of median cusp. Tooth base oval, wide mesiodistally, and compressed labiolingually in both specimens. Slight lingual boss present on oral-lingual margin of MNA V11265 (Fig. 5.2). Faint basolabial projection present on both specimens. Denticles (Fig. 5.55.9) monocuspid with the cusp long, narrow, and circular in cross section. Surface of cusp is smooth. Bases of denticles are elliptical with three to four lateral foramina and single ventral and dorsal foramina.

Material.-MNA V11265, tooth; MNA V11266, tooth; MNA V11267, MNA V11268, MNA V11269, denticles.

Remarks.-The poor preservation of the two teeth make a generic designation difficult, but these teeth can be classified as stethacanthid from the proportion of the cusps and position of the lingual boss. Stethacanthid dentitions are cladodont, but tend to have smaller lateral cusps in relation to the median cusp than in falcatid sharks, which have much larger lateral cusps (Ginter et al., 2010). The lingual boss in stethacanthids is not positioned near the lingual margin as it is in the falcatid Denaea williamsi Ginter and Hansen, 2010, and tends to be positioned forward as a short longitudinal ridge or square boss that is approximately the width of the median cusp (Zidek, 1993; Coates and Sequeria, 2001; Ginter and Hansen, 2010; Ginter et al., 2010). Larger species, such as Stethacanthus altonensis St. John and Worthen, 1875 and Akmonistion zangerli Coates and Sequeria, 2001, have coarse longitudinal cristae (Zidek, 1993; Coates and Sequeria, 2001), similar to those seen in MNA V11266 but the Surprise Canyon specimen is much smaller. The teeth of the Surprise Canyon specimens fit the expected size range of dentition for the small stethacanthid Orestiacanthus fergusi Lund, 1984, however at present the dentition of Orestiacanthus is not well known (Lund, 1984; Ginter, et al., 2010). Lund (1985a) described additional stethacanthids from Bear Gulch, which would fit the expected dental range for the Surprise Canyon specimens, but presently the dentition of these specimens is poorly understood. At present, the Surprise Canyon specimens are best regarded as stethacanthid indeterminate.

$$
\begin{gathered}
\text { Family Falcatidae Zangerl, } 1990 \\
\text { Falcatid indeterminate } 1 \\
\text { Figure 5.10-5.16 }
\end{gathered}
$$

Occurrence.-Surprise Canyon Formation, middle member, latest Mississippian (Serpukhovian); Bat Tower 2 overlook section 15 .
Description.—Five small cladodont teeth, $\sim 600 \mu \mathrm{m}$ wide mesiodistally. Cusps with longitudinal cristae and arranged in a slight arc on labial margin of the base. Median cusp tall, narrow, and circular in cross section with lateral and intermediate cusps angling away from it. In some specimens (MNA V11270, MNA V11271, and MNA V11274; Fig. 5.10, 5.11, 5.13-5.15), a lingual ridge present. In all specimens, lingual torsus of tooth base short, with two flanking oral foramina, and no lingual foramen or articulating orolingual boss. Some specimens have two or three slight oral depressions flanking midline of tooth base. Basolabial projection absent or forms slight narrow bulge.

Material.-Five teeth: MNA V11270; MNA V11271; MNA V11272, MNA V11273, MNA V11274.

Remarks. - These five teeth are characterized as being from a small falcatid shark based on their slender median cusp, subparallel cristae on both labial and lingual sides of the cusps, and narrow lingual torus of the tooth base (Lund, 1985b; Ginter et al., 2010). The lack of an orolingual boss on the lingual margin of the tooth eliminates placement of these teeth in Denaea, which bears this feature in varying degrees depending on species (Ginter and Hansen, 2010; Ginter et al., 2010). The teeth of Stethacanthulus are characterized by the absence of the orolingual boss, but differ from the Surprise Canyon specimens in having a single median foramen piercing the lingual torus and a labiolingual groove on the oral surface (Zangerl, 1990; Ginter et al., 2010). Lund (1985b) described the teeth of Falcatus falcatus Lund, 1985b as having a maximum base length of $0.3 \mathrm{~mm}$ and a narrow lingual torus with five cusps, but also noted the teeth were too small to determine if cristae were present. Lund (1986) described the teeth of Damocles serratus Lund, 1986 as being five cusped, the median cusp the largest, and cusps ornamented with fine cristae. Ginter et al. (2010) noted that the lateral cusps were half the height of the median cusp. The lingual torus is relatively narrow with a vaguely defined orolingual button and has a very narrow, rounded basolabial projection (Lund, 1986; Ginter et al., 2010). Another possible identification for these specimens is Ozarcus mapesae Pradel et al., 2014 from the Fayetteville Formation in Arkansas (Pradel et al., 2014). Although the description by Pradel et al. (2014) focused primarily on the visceral skeleton, they did present images of teeth from computed tomography scanning. These teeth are $\sim 1 \mathrm{~mm}$ wide mesiodistally with a very tall slender median cusp and lateral cusps almost half the height of the median cusp. In labial and lingual views, no well-developed orolingual or basolabial articulating processes appear to be present (Pradel et al., 2014, extended data fig. 2C). At this stage, however, it is difficult to determine which taxon the teeth described here belong to, although superficially they look most similar to Falcatus falcatus, Damocles serratus, or Ozarcus mapesae. It is presently best to keep the designation to falcatid indeterminate 1 until new data and specimens became available. This taxon is known only from the type locality Bat Tower 2, section 15 and has not yet been identified elsewhere. Bat Tower 2 is located in the 
western more open water environment of the Surprise Canyon embayment.

\section{Falcatid indeterminate 2 \\ Figure 5.17}

Occurrence.-Surprise Canyon Formation; middle member; latest Mississippian (Serpukhovian); Blue Mountain Canyon locality 84-9, section 3 .

Description.-Single tooth of small falcatid shark with mesiodistal width of $\sim 1 \mathrm{~mm}$ (Fig. 5.17). Cusps missing, but base of cusps suggests crown was circular with coarse cristae on labial and lingual sides. Cusps nearly in line and inclining lingually. Tooth base labiolingually compressed with a shallow elliptical shape. Lingual torus very slightly extended. Single well-developed foramen present on lingual margin, dividing two rounded orolingual projections that are merged with lingual rim and have five evenly spaced foramina labial to them.

Material.-MNA V11275.
Remarks.-The morphology of the orolingual projections in this specimen is fairly rare among the falcatids. The only other cladodont sharks with divided orolingual projections are the ctenacanths Glikmanius, Heslerodus, "Ctenacanthus" costellatus Traquair, 1884, Kaibabvenator, and Nanoskalme (Ginter et al., 2010; Hodnett et al., 2012). However, the placement of these structures in the ctenacanths is forward of the lingual rim and they do not have a complex of evenly spaced foramina along the labial side of the projections. Both Denaea saltsmani Ginter and Hansen, 2010 and D. williamsi have single orolingual projections on the lingual rim of the tooth base, which bears a single large nutrient foramen, and few nutrient foramina are present just labial of the orolingual projection (Ginter and Hansen, 2010; Ginter et al., 2010). However, we feel that the unique morphology of the divided orolingual projections and the arrangement of the labially positioned oral nutrient foramen suggest that this is a unique taxon with a close relationship to Denaea.

Genus Denaea Pruvost, 1922

Denaea williamsi Ginter and Hansen, 2010

Figure 6.1-6.19

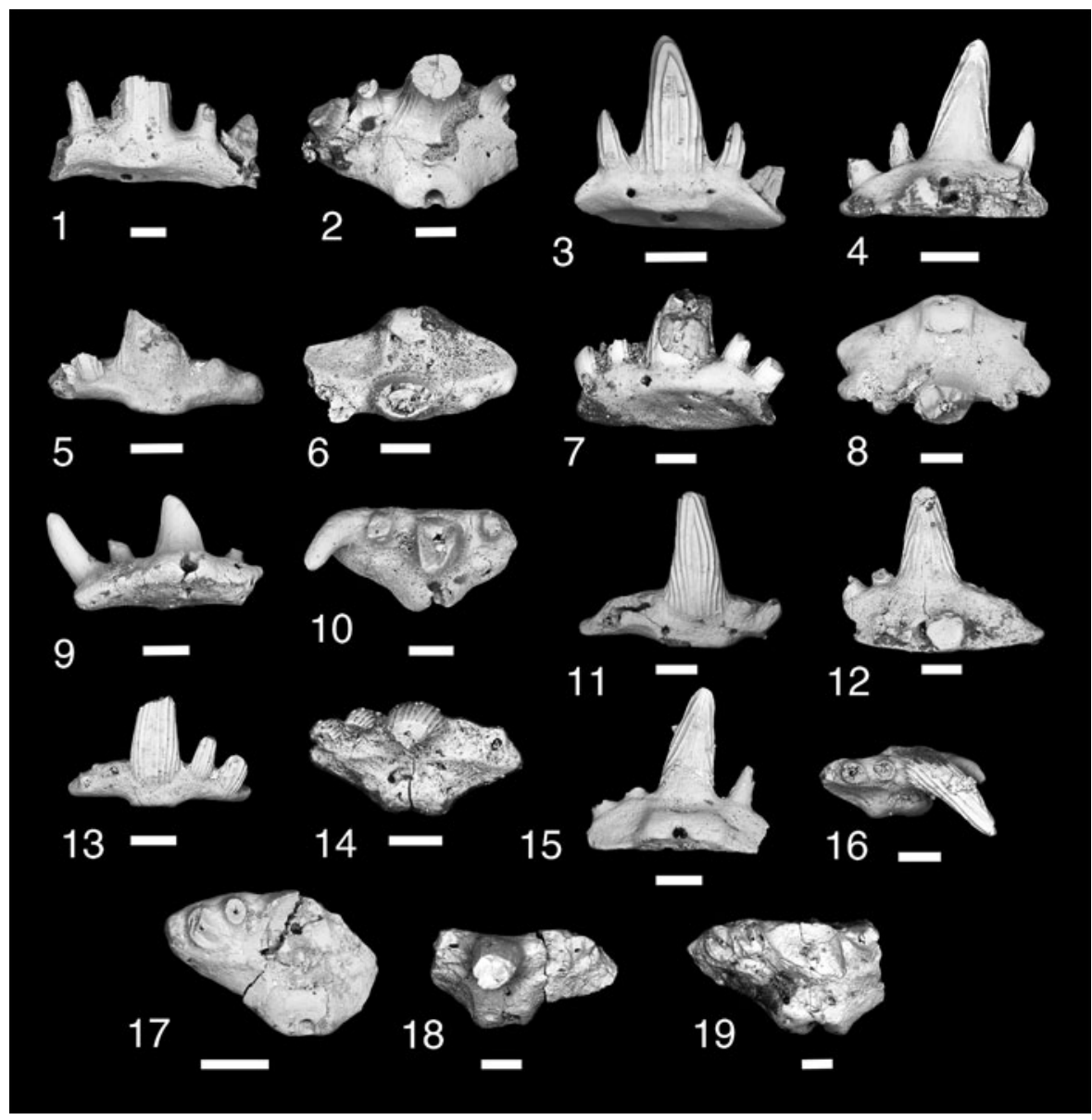

Figure 6. Teeth of Denaea williamsi. (1, 2) MNA V11277, (1) labial view, (2) occlusal view; $(\mathbf{3}, \mathbf{4})$ MNA V11278, (3) labial view, (4) lingual view; (5, 6) MNA V11276, (5) labial view, (6) occlusal view; (7, 8) MNA V 11286, (7) oblique labial view, (8) occlusal view; (9, 10) MNA V11285, (9) lingual view, (10) occlusal view; $(\mathbf{1 1}, \mathbf{1 2})$ MNA V11279, (11) labial view, (12) lingual view; (13, 14) MNA V11280, (13) labial view, (14) occlusal view; (15, 16) MNA V11283, (15) lingual view, (16) occlusal view; (17) MNA V11281, occlusal view; (18) MNA V11284, occlusal view; (19) MNA V11287, occlusal view. Scale bars $=200 \mu \mathrm{m}$. 
Holotype.-Denaea williamsi Ginter and Hansen, 2010, p. 34, fig. 3. Tooth (IGPUW/Ps/8/1) from the Grove Creek Shale, unit 12, Cedar Grove Church, Johnson County Illinois, USA.

Occurrence.-Surprise Canyon Formation; middle member; latest Mississippian (Serpukhovian); Bat Tower 2, section 13; Blue Mountain Canyon locality 4, section 2; Blue Mountain Canyon locality 84-9, section 3 .

Description.- Small cladodont teeth with five cusps recurving lingually. Labial surface of cusp with three to five coarse cristae. Lingual cusp surface has a few cristae that terminate a third of the distance from base of crown leaving distal part of lingual surface smooth. Median cusp tall, broad near base, circular in cross section, and tapers to a narrow point. Lateral and intermediate cusps splay mesiodistally with lateral cusp larger than intermediate cusp and about half the height of the median cusp. Tooth base trapezoidal. Square oral-lingual button present on median lingual margin, which has a large foramen in center. Basolabial projection thin and shallow, with labial aboral margin nearly flat. Single labial foramen present on either side of basolabial projection. Single median aboral foramen present.

Material. -12 teeth: MNA V11276, MNA V11277, MNA V11278, MNA V11279, MNA V11280, MNA V11281, MNA V11282, MNA V11283, MNA V11284, MNA V11285, MNA V11286, MNA V11287.

Remarks.-Ginter and Hansen (2010) described this taxon from a series of teeth from the Serpukhovian of Illinois. It is also known from the late Visean of the Holy Cross Mountains, Poland (Ginter et al., 2015), the Visean-Serpukhovian of Derbyshire, England, Scotland, and the Moscow Syneclise, Russia (Ginter et al., 2010), and tentatively Denaea cf. D. williamsi from the late Serpukhovian fauna from the Gissar Mountains, Uzbekistan (Ivanov, 2013). Denaea williamsi is known from the type section of the Surprise Canyon
Formation (Bat Tower 2) and from the eastern near-shore Blue Mountain localities.

\author{
Order Ctenacanthiformes Glikman, 1964 \\ Family Ctenacanthidae Dean, 1909 \\ Genus Cladodus Agassiz, 1843 \\ Cladodus cf. C. marginatus Agassiz, 1843
}

Figure 7.8

Occurrence.-Surprise Canyon Formation, upper member, Late Mississippian (Serpukhovian), Stairway Canyon, unit 5.

Description. - Tooth base, $\sim 160 \mathrm{~mm}$ wide, exposed lingually in a sandy limestone nodule (Fig. 7.8). Cusps broken or worn. Cross section of median cusp indicates it was labiolingually compressed. Lateral cusps closely spaced and originate together on labial margin of tooth base, which is reniforme or "D-shaped." Oral-lingual ridge forms near lingual margin of tooth, terminating approximately at intermediate cusps, and has two lingual foramina.

Material.-USNM PAL 412169, tooth.

Remarks. - This specimen is the largest of the "cladodont" tooth morphs from the Surprise Canyon Formation. Its placement as a ctenacanthiform is supported by remnants of a prominent median cusp, convex lingually and labially flattened, the cusps connected by enamel, and a lingually deep base with a wide orolingual ridge that is wider than the median cusp (Duffin and Ginter, 2006; Ginter et al., 2010). Identification as Cladodus is based on its mesiodistally wide median cusp, wide tooth base with wide orolingual ridge, and its relatively large size. The tentative placement of this specimen as Cladodus cf. C. marginatus is based on the relatively close position of the lateral and intermediate cusps to the median cusp and the labiolingual compression of all the cusps (Duffin and Ginter, 2006; Ginter et al., 2010). The fragmentary nature of USNM PAL 412169 means this identification is tentative. This represents the youngest occurrence of $C$. marginatus and

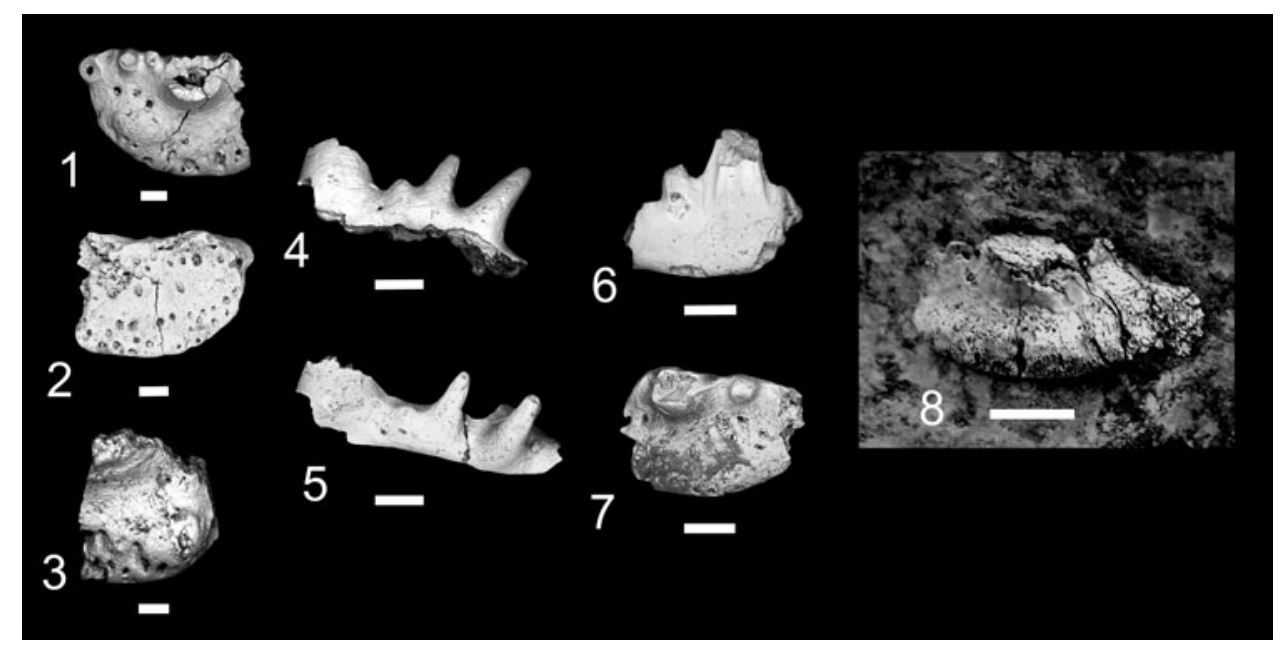

Figure 7. Teeth of Ctenacanthiformes. (1-5) cf. "Ctenacanthus" costellatus; $(\mathbf{1}, \mathbf{2})$ MNA V11288, (1) occlusal view, (2) aboral view; (3) MNA V11289, occlusal view; $(\mathbf{4}, \mathbf{5})$ MNA V11290, (4) labial view, (5) oblique occlusal view. (6, 7) ctenacanth indeterminate, MNA V11291, (6) labial view, (7) occlusal view. (8) Cladodus cf. C. marginatus, USNM PAL 412169, lingual view. Scale bars $=200 \mu \mathrm{m}(\mathbf{1 - 7}) ; 1 \mathrm{~cm}(\mathbf{8})$. 
the first record of this taxon outside the vicinity of Armagh, Northern Ireland (Duffin and Ginter, 2006; Ginter et al., 2010). This specimen was collected from the easternmost Stairway Canyon locality from the upper member of the Surprise Canyon Formation, which was formed during the open water phase of deposition. The paleogeographic position of the locality suggests that the tooth was deposited in open water, some distance from the paleo-shoreline.

\section{Family uncertain \\ cf. "Ctenacanthus" costellatus Traquair, 1884}

Figure 7.1-7.5

Holotype.-Ctenacanthus costellatus Traquair, 1884, p. 3, pl. 2, figs. 1-7. Nearly complete specimen (NHM-P 5900) from Eskdale, Dumphreshire, Scotland.

Occurrence.-Surprise Canyon Formation; middle member; latest Mississippian (Serpukhovian); Blue Mountain Canyon locality 4 , section 2 .

Description.-Three small fragmentary teeth. A small fragment with no tooth base has worn median cusp, lateral cusp, and two intermediate cusps inclined mesially (Fig. 7.4, 7.5). Two fragmentary tooth bases have rounded oral-lingual buttons and elliptical basolabial projections.

Material.-Three teeth: MNA V11288, MNA V11289, MNA V11290.

Remarks.-These teeth are tentatively identified as cf. "Ctenacanthus" costellatus based on having two intermediate cusps and two separate button-like orolingual and basolabial projections, as also seen in the specimens referred to by Ginter (2002) from the type locality of Eskdale, Dumphrieshire, Scotland (Traquair, 1884; Moy-Thomas, 1936; Ginter, 2002; Ginter et al., 2010). The Surprise Canyon specimens differ from the Eskdale specimens in that the orolingual projections are spaced farther apart and are found closer to the lingual margin of the tooth base. The two separate orolingual and basolabial projections are also found in the Pennsylvanian and Permian genera Glikmanius, Heslerodus, Kaibabvenator, and Nanoskalme; although these taxa have variable cusp morphologies (although typically a single or no intermediate cusp) and basolabial depressions (Ginter, 2002; Ginter et al., 2005, 2010; Hodnett et al., 2012). The generic status of " $C$." costellatus needs review as Ginter et al. (2010) has shown that the teeth of the Devonian Ctenacanthus differ from those from the teeth of " $C$." costellatus in having a single ridge for the orolingual and basolabial projections. Along with the specimens from Glencartholm, Scotland (Visean) (Traquair, 1884; Moy-Thomas, 1936), "C." costellatus has also been recognized from the late Visean of Ticknall, Derbyshire, England, and the Holy Cross Mountains, Poland (Ginter et al., 2015). The Surprise Canyon species is only known from the near shore deposit of Blue Mountain Canyon locality 4, in the lower second section. This may be the youngest and the first Western Hemisphere example of "C." costellatus.
Ctenacanthidae indeterminate Figure 7.6, 7.7

Occurrence.-Surprise Canyon Formation; middle member; latest Mississippian (Serpukhovian); Blue Mountain Canyon locality 4 , section 2 .

Description. - Tooth fragment. Median cusp narrow with coarse cristae. Intermediate cusp small, closely associated with median cusp. Tooth base reniform with low basolabial ridge, wider than median cusp and thick dorsoventrally. Orolingual ridge weakly developed along lingual rim and wider than median cusp. Basolabial depression is absent.

Material.-Tooth fragment: MNA V11291.

Remarks.-An indeterminate ctenacanth is present in the Surprise Canyon Formation, which differs from the "Ctenacanthus" costellatus and Cladodus marginatus morphs. The tooth base fragment is similar to Cladodus in being reniform in shape and having elongated orolingual and basolabial ridges, although rather weakly developed. The basolabial depression, which is moderately developed in Cladodus, is absent in this taxon. The enamel on the preserved crowns does connect between the cusps, which is a ctenacanth trait (Ginter et al., 2010). This tooth is similar to two indeterminate ctenacanth taxa from the Mississippian. Behan et al. (2012) described a series of teeth, designated Ctenacanthiformes indet. A, from the Tournasian karst residues of Cromhall Quarry, Gloucestershire, England. This tooth morph has a prominent median cusp with coarse cristae, a mesiodistally wide tooth base with very little indication of a basolabial depression, and a slight orolingual ridge along the lingual rim (Behan et al., 2012). However, the Surprise Canyon taxon differs from the Cromhall Quarry taxon in the position of the intermediate cusp, which is closer in association to the median cusp and has a thicker tooth base. Ginter et al. (2015) described two teeth from the late Visean of the Holy Cross Mountains of Poland, which are also similar to the Surprise Canyon and Cromhall Quarry taxa in having a median cusp with a few coarse labial cristae and seemingly having an underdeveloped basolabial depression. The Holy Cross taxon differs from the Surprise Canyon and Cromhall taxa in having an orolingual ridge that is more well developed, and less wide mesiodistally than the other two taxa. Ginter et al. (2015) considered that the Holy Cross taxon represented juvenile specimens; in contrast we feel that the Surprise Canyon taxon may represent a small adult form.

\section{Primitive Elasmobranchii incertae sedis Genus Clairina Ginter, 1999 Clairina sp. Figure 8.1-8.4}

Occurrence.-Surprise Canyon Formation, middle member, latest Mississippian (Serpukhovian), Bat Tower Locality 2, sections 13 and 15. 


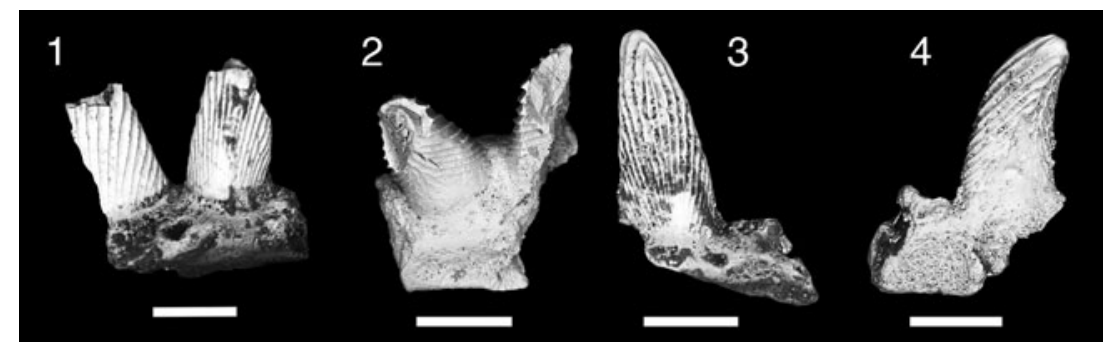

Figure 8. Teeth of Clairina sp. (1, 2) MNA V11292, (1) labial view, (2) lingual view; (3, 4) MNA V11293, (3) labial view, (4) lingual view. Scale bars = 200 $\mu$ m.

Description.-Two small fragmentary multicuspid teeth. Cusps long and slender, recurving lingually. Labial surface of cusps covered by elongated, overlapping, leaf-shaped cristae that narrow towards the base. Lingual surface of the cusp covered by short $\mathrm{v}$-shaped cristae that diverge towards mesiodistal edge of the cusp. One to two vein-like cristae also occur on the midline of lingual side of cusp. The base is moderately flattened and plate-like, with little evidence of a well-developed lingual torus.

\section{Material._Two teeth: MNA V11292, MNA V11293.}

Remarks. - The Surprise Canyon specimens are the first record of the genus Clairina extending into the Carboniferous. The two fragments from the Surprise Canyon Formation were collected from the type section, Bat Tower 2, but at two separate intervals, sections 13 and 15 of the middle member. These teeth are not Denaea williamsi because we see no evidence of a lingual torus of the tooth base. MNA V11292 (Fig. 8.1, 8.2) shows an enlarged intermediate cusp compared to the median cusp, and the median cusp of MNA V11293 (Fig. 8.3, 8.4) shows the cristae on the lingual side are extending mediodistally from the midline of the tooth, with no indication of vertical cristae as seen on in D. williamsi. Clairina was previously recognized from the Late Devonian, Famenian, of the Anti-Atlas region of Morocco (Derycke, 1992), Thuringia of Germany (Ginter, 1999), and Holy Cross Mountains of Poland (Ginter, 1995). The morphology of Clairina teeth, consisting of five lingually recurved cusps that reduce in height laterally from the tall median cusp, and with fluted cristae and a tooth base that is slightly extended lingually, suggests a primitive placement within the Elasmobranchii (Ginter et al., 2010).

Cohort Euselachii Hay, 1902

Superfamily Protacrodontoidea Zangerl, 1981

Family Protacrodontidae Cappetta, Duffin, and Zidek, 1993 Genus Microklomax new genus

Type species.-Microklomax carrieae n. gen. n. sp.

Diagnosis._As for species, by monotypy.

Etymology.-Greek mikros, little; Greek klomax, heap of stones; in recognition of its small size and its multiple round cusps.

Remarks._-See remarks for species.

\section{Microklomax carrieae new species}

Figure 9.1-9.17

Holotype.-MNA V11294, mediolateral tooth.

Diagnosis. - Small heterodont durophagous protacrodont shark with multicuspid teeth $\sim 1 \mathrm{~mm}$ long mesiodistally, $400 \mu \mathrm{m}$ wide labiolingually, and 300-400 $\mu \mathrm{m}$ tall (Fig. 9.3, 9.4 holotype MNA V11294). Tooth base shallow, curved aborally or moderately flattened, mesiodistally elongated, and lingually offset from crown. Enlarged foramina in a single row on lingual and labial margins of tooth base. Tooth crown with prominent median cusp that is either compressed labiolingually or rounded, one to two lateral cusps near equal in height, labial and lingual horizontal ridges forming cingulum, and labial and lingual vertical ridges on cusps.

Occurrence.-Bat Tower locality 2, sections 13 and 18; Blue Mountain Locality 4, section 2; Burnt Springs Canyon locality 6, section 1, Surprise Canyon Formation, lower and middle member, Serpukhovian, Grand Canyon, Mohave County Arizona.

Description.-The tooth base is plate-like and rectangular, concave aborally, and offset to the crown lingually. Height of base varies with tooth position; thicker in anterior and mediolateral teeth and thin in posterolateral teeth. Large nutrient foramina are present on labial and lingual margins and are positioned in line with one another. An aboral vascular channel is directly positioned under the crown with a smooth lingual margin on the aboral side. Crown morphology varies with tooth position. All tooth crowns share the traits of a blunt ridge on either side of each cusp extending mesiodistally, a labial and/or lingual ridge forming a cingulum, and one to three coarse vertical cristae on each cusp. Anterior and mediolateral teeth are labiolingually compressed with median cusp very large in comparison to lateral cusps. Median cusps for anterior and mediolateral teeth are triangular with mediolateral median cusp being proportionately thicker than in more anteriorly positioned teeth. Apex of median cusp is blunt. Anterior tooth has a single small lateral cusp and mediolateral tooth has two small lateral cusps, descending slightly in height. Lateral and posterolateral teeth have a lower cusp height than anterior and mediolateral teeth. Median cusp subtriangular or almost circular with a rounded blunt apex. Two lateral cusps are present on either side of median cusp. Height of lateral cusps 


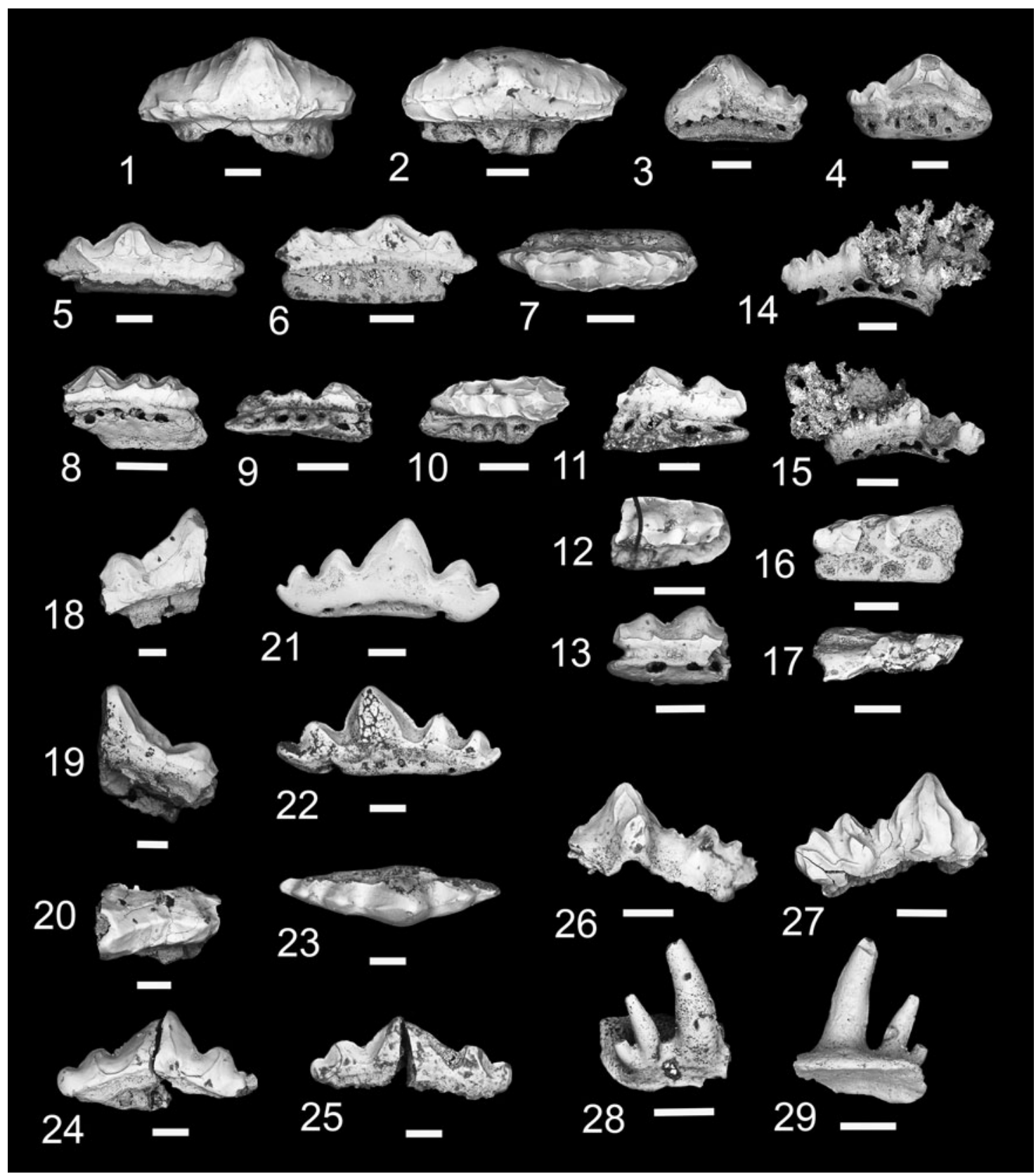

Figure 9. Teeth and denticles of Protacrodontiformes and Hybodontiformes. (1-17) Microklomax carriea n. gen. n. sp.; (1, 2) MNA V11297, anterior tooth, (1) labial view, (2) occlusal view; (3, 4) MNA V11294, holotype, anterior tooth, (3) labial view, (4) lingual view; (5-7) MNA V11298, mediolateral tooth, (5) labial view, (6) lingual view, (7) occlusal view; (8-10) MNA V11296, posterior tooth, (8) labial view, (9) lingual view, (10) occlusal view; (11-13) MNA V11300, posterior tooth, (11) lingual view, (12) occlusal view, (13) labial view; $(\mathbf{1 4}, \mathbf{1 5})$ MNA V11295, posterior tooth, (14) lingual view, (15) labial view; (16, 17) MNA V1299, posterior tooth, (16) lingual view, (17) occlusal view. (18-25) Novaculodus billingslevi $\mathrm{n}$. gen. n. sp.; (18-20) MNA V11303, anterior tooth, (18) lingual view, (19) labial view, (20) occlusal view; (21-23) MNA V11301, holotype, lateral tooth, (21) labial view, (22) lingual view, (23) occlusal view; (24, 25) MNA V11302, (24) labial view, (25) lingual view. (26, 27) cf. Mesodmodus sp., MNA V11304, (26) labial view, (27) lingual view; (28, 29) cf. Hamiltonichthyes sp., MNA V11305, (28) anterior view, (29) posterior view. Scale bars $=200 \mu \mathrm{m}$.

in lateral and posterolateral teeth are nearly equal and they have rounded, blunt apices.

Etymology.-In honor of Carrie Brugger-Schorr of Northern Arizona University, who brought to our attention the microvertebrate material used in this study.

Material.-Teeth: MNA V11295, MNA V11296, MNA V11297, MNA V11298, MNA V11299, MNA V11300.
Remarks. - The teeth of Microklomax carrieae n. gen. n. sp. are placed in the Protacrodontidae based on the vascular canal morphology of the tooth base, which consists of a single row of large oval foramina. This feature is also seen in the Late Devonian (Frasnian-Famenian) Protacrodus vetustus Jaekel, 1925, which also has a single row of oval foramina together with a large median cusp (Gross, 1938; Ginter et al., 2010). Other Protacrodus species, P. serra Ginter, Hairapetian, and Klug, 2002 and $P$. aequalis Ivanov, 1996 have proportionately 
smaller vascular foramina compared to $M$. carrieae n. gen. n. sp. and P. vetustus. Deihim mansureae Ginter, Hairapetian, and Klug, 2002, which is placed tentatively within the Protacrodontidae, has a more elongated lingual torsus for the tooth base than Protacrodus and Microklomax n. gen. (Ginter et al., 2002). In addition to a more elongated lingual torus, the vascular foramina are distributed more irregularly lingually, in a more hybodont-like anascularized fashion.

The crown of Microklomax carrieae n. gen. n. sp. shows a typical protacrodont design, as seen in Protacrodus and Deihim, in which there is a tall median cusp flanked by two or three lateral cusps that are near to or equal in height to one another (Ginter et al., 2010). Typically, Protacrodus and Deihim have three lateral cusps on the post-anterior tooth families, although Ginter and Sun (2007) described a set of protacrodont teeth as "Protacrodus sp." from the early Mississippian of Muhua, Southern China that had two lateral cusps. The crown of $M$. carrieae n. gen. n. sp. differs from Protacrodus and Deihim in having low, robust, blunt, median, and lateral cusps that are expanded labiolingually. Microklomax $\mathrm{n}$. gen. is similar to both Protacro$d u s$ and Deihim in having cusps ornamented with longitudinal coarse ridges that can extend along the rim of the crown and to the apex of the cusps. Deihim was described as being a possibly durophagous protacrodont shark based on having cusps that are rounded as compared to Protacrodus (Ginter et al., 2002, 2010). However, the teeth of Microklomax n. gen. are far more developed for durophagous feeding than either Protacrodus or Deihim, and it is considered here to be the first true durophagous protacrodont shark.

\section{Genus Novaculodus new genus}

Type species.—Novaculodus billingsleyi n. gen. n. sp.

Diagnosis.—As for species by monotypy.

Etymology.-Latin novacula, razor; Latin odus, tooth; in recognition of its tall, well developed labiolingually compressed cusps.

Remarks.-See remarks for species.

Novaculodus billingsleyi new species

Figure 9.18-9.25

Holotype.-MNA V11301, a lateral tooth.

Diagnosis.-Small multicuspid heterodont protacrodont shark with laterally compressed dentition, teeth $1-1.5 \mathrm{~mm}$ long mesiodistally, $400 \mu \mathrm{m}$ wide labiolingually, and $\sim 600 \mu \mathrm{m}$ tall (Fig. 9.21-9.23 holotype MNA V11301). Tooth base shallow, aborally recurved or moderately flattened, and slightly extended lingually. Four to six nutrient foramina present in a single row on labiolingual margin of tooth base. Crown with prominent labiolingually compressed triangular median cusp, one to three laterally compressed lateral cusps with broad longitudinal crests present on each cusp.
Occurrence.-Surprise Canyon Formation, middle member, latest Mississippian (Serpukhovian), Bat Tower Locality 2, sections 13 and 1; Blue Mountain Locality 4, section 2.

Description.-Taxon represented by three teeth comprising an anterior or mediolateral tooth and two lateral teeth. Tooth bases are thin with ovate nutrient foramina that extend through labial margin to lingual margin of base. Shallow aboral longitudinal groove present labially under the crown. Lingual torus reduced in width. In all teeth cusps are labiolingually compressed with smooth cutting carina, triangular median cusp, and lateral cusps about a quarter the height of median cusp and only slightly reducing in height mesiodistally. Broad longitudinal lingual crest extends between each cusp, a similar, though less well developed, longitudinal crest is present labially. A smaller longitudinal crest can be present along the labial and lingual rim of crown. Specimen representing a possible anterior or mediolateral tooth (MNA V11303) shows that the median crown was proportionately broader mesiodistally than in the lateral teeth, and more triangular. A single lateral cusp is present on a mesiodistally shorter base. Lateral teeth elongated mesiodistally with prominent median and lateral cusps.

Etymology.-In honor of George H. Billingsley for his contributions to the study of the Surprise Canyon Formation in the Grand Canyon.

Material.-Two teeth: MNA V11302, lateral tooth; MNA V11303, anterior or mediolateral tooth.

Remarks.-Novaculodus billingsleyi n. gen. n. sp. is placed in the Protacrodontidae based on the vascularization pattern of its tooth base, which consists of a single row of oval nutrient foramina that extends labiolingually through the tooth base. Novaculodus billingsleyi n. gen. n. sp. differs from Microklomax n. gen., Protacrodus, and Deihim in having a reduced width of the lingual torus. The crown of Novaculodus n. gen. differs from Microklomax n. gen., Protacrodus, and Deihim in being more labiolingually compressed with more blade-like cusps. The teeth of Novaculodus n. gen. bear a superficial resemblance to Sphenacanthus because both taxa have tall triangular median cusps (Dick, 1998; Ginter et al., 2010). However, Sphenacanthus differs from Novaculodus n. gen. in having a more developed lingual torus, with numerous vascular foramina that do not form a single row labiolingually, and the cusps of Sphenacanthus are ornamented with numerous thin longitudinal cristae (Dick, 1998; Ginter et al., 2010). Microklomax carrieae n. gen. n. sp. and Novaculodus billingsleyi n. gen. n. sp. represent a further temporal extension and diversification of the protacrodontids into the latest Mississippian (Serpukhovian), as previous records only extended into the earliest Mississippian (Tournaisian) and only referred to Protacrodus (Ginter and Sun, 2007; Ginter et al., 2010). These two taxa also show two new extremes in dental morphology for the protacrodontidsa durophagous morphotype and a hyper-carnivorous morphotype. Taxa like Protacrodus and Deihim had a more generalized crown morphology for grasping and some crushing. 


\author{
Order Hybodontiformes Maisey, 1975 \\ Family Indeterminate \\ Genus Mesodmodus St. John and Worthen, 1875 \\ cf. Mesodmodus sp.
}

Figure 9.26, 9.27

Occurrence.-Surprise Canyon Formation, middle member, latest Mississippian (Serpukhovian), Blue Mountain locality 4, section 2 .

Description.-Tooth crown without base. Median cusp is triangular with a thick carina on the mesiodistal margins (Fig. 9.26, 9.27). Four lateral cusps are present with that closest to the median cusp greatly reduced in size. All cusps have one to three thick sinuous cristae. A small peg-like labial node is present.

Material.-MNA V11304, tooth.

Remarks.-This tooth is tentatively identified as Mesodmodus, an enigmatic hybodont taxon from the early Mississippian (Tournaisian) of North America and Belgium (Ginter et al., 2010). The crown of Mesodmodus consists of a prominent median cusp and a series of smaller lateral cusps ornamented by vertical striations that descend from the crown apex to the junction of the base, and which commonly bifurcate (Ginter et al., 2010). Additionally, the Surprise Canyon specimen also has labial nodes near the midline of the median cusp, a feature that is present in most species of Mesodmodus except M. khabenji Derycke-Khatir, 2005 (Ginter et al., 2010). The Surprise Canyon specimen is morphologically similar to $M$. khabenji in having more prominent lateral cusps and robust vertical striations, but overall it is more robust than M. khabenji (Derycke-Khatir, 2005) and less mesiodistally elongated than M. exsculptus St. John and Worthen, 1875, M. explanatus St. John and Worthen, 1875, and M. ornatus St. John and Worthen, 1875 (St. John and Worthen, 1875).

\section{Genus Hamiltonichthys Maisey, 1989 cf. Hamiltonichthys sp.}

Figure 9.28, 9.29

Occurrence.-Surprise Canyon Formation; middle member; latest Mississippian (Serpukhovian); Blue Mountain Canyon locality 84-9, section 3 .

Description.-Partial cephalic spine from a small hybodont shark with a mediolateral width of $\sim 400 \mu \mathrm{m}$, an anteroposterior length of $\sim 300 \mu \mathrm{m}$, and an approximate height of $500 \mu \mathrm{m}$. Spine base is rectangular with two posterior foramina; dorsal surface of the spine base slightly rugose and thickens slightly mediolingually. Ventral surface of spine base smooth with no indication of foramina. Denticles consist of a tall narrow median cusp with two smaller and narrow lateral cusps. Cusps are smooth, slightly inclined posteriorly, and circular in cross section.

Material.-MNA V11305, cephalic spine.
Remarks.-A single multicuspid cephalic spine from the vicinity of Blue Mountain Canyon suggests the presence of a small male hybodont in the Surprise Canyon embayment. In the extinct Elasmobranchii, only male hybodont sharks had cephalic spines (Maisey, 1982a). There are two Paleozoic hybodont taxa that had multicuspid cephalic spines: Onychoselache traquairi Dick, 1978 and Hamiltonichthys mapesi Maisey, 1989. Onychoselache is from the late Mississippian of Scotland, but can be excluded here in that the cephalic spine base is anteroposteriorly elongated with three cusps of equal height, one anterior cusp and paired posterior cusps (Coates and Gess, 2007). The cephalic spines of Hamiltonichthys are multicuspid, positioned on the anterior end of an anteroposteriorly compressed plate in a transverse row, with the cusps connected by enamel (Maisey, 1989). The median cusp of the cephalic spine of Hamiltonichthys is strongly recurved posteriorly with the three lateral cusps less recurved (Maisey, 1989), features shared by the Surprise Canyon taxon. The Surprise Canyon taxon shares also with Hamiltonichthys cusps that are circular in cross-section and a thick central area of the basal plate (Maisey, 1989). However, the Surprise Canyon spine differs from the type material of Hamiltonichthys in having only two lateral cusps and being approximately a quarter of the dimensions of Hamiltonichthys spines.

Subcohort Neoselachii Compagno, 1977

Family Anachronistidae Duffin and Ward, 1983

Genus Coolyella Gunnell, 1933

Cooleyella fordi Duffin and Ward, 1983

Figure 10.13-10.15

Holotype.—Coolyella peculiaris Gunnell, 1933, p. 290. Tooth (NHM-P60670) from Steeplehouse Quarry, Derbyshire England.

Occurrence.-Surprise Canyon Formation, middle member, latest Mississippian (Serpukhovian), Blue Mountain locality 4, section 2 .

Description.—Single tooth $\sim 1 \mathrm{~mm}$ mesiodistally, $600 \mu \mathrm{m}$ labiolingually, and $600 \mu \mathrm{m}$ tall (Fig. 10.13-10.15). Crown consists of a lingually directed central cusp and two lateral blades with cutting carinae directed orolingually. Left lateral blade mesiodistally longer than right lateral blade. Central cusp somewhat prominent and triangular. Labial face of crown extends downwards forming rounded basal flange that just overlaps basolabial projection. Basal flange has slight ridge on right labial margin of crown. Tooth base consists of single basolabial peg-like projection and a wide transverse lingual basal ridge. Central pit with aboral foramen between the basolabial projection and transverse lingual basal ridge. Small median orolingual foramen present on lingual basal ridge.

\section{Material.-Tooth: MNA V11306.}

Remarks. - The teeth of Cooleyella fordi are known primarily from the Visean (Late Mississippian) of the Steeplehouse Quarry near Matlock, Derbyshire, England, but also from a 


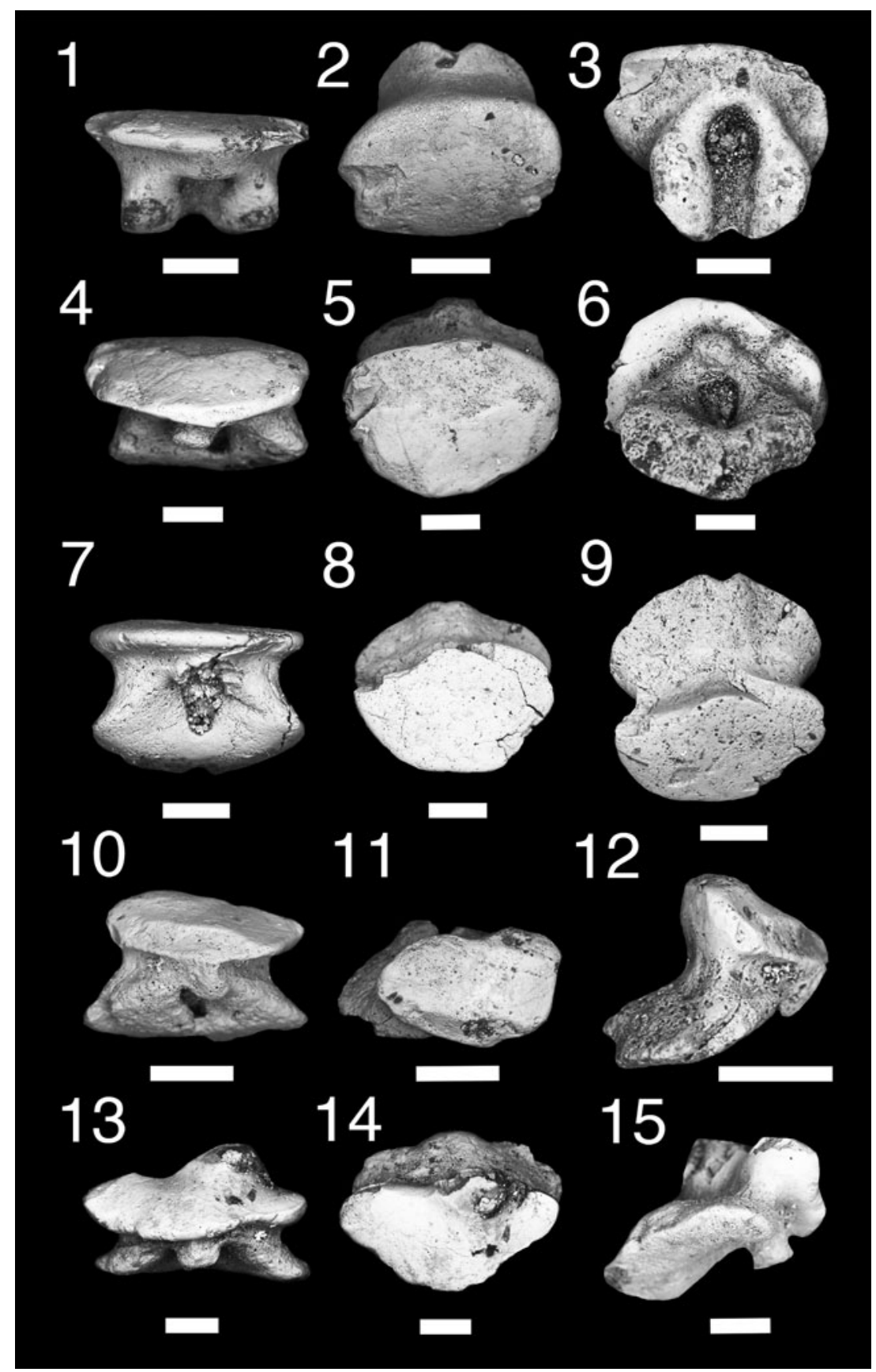

Figure 10. Teeth of Anachronistidae. (1-12), Cooleyella platera n. sp.; (1-3), MNA V11308, tooth, (1) labial view, (2) occlusal view, (3) aboral view; (4-6), MNA V11307, holotype, tooth, (4) labial view, (5) occlusal view, (6) aboral view; (7-9), MNA V11311, tooth, (7) labial view, (8) occlusal view, (9) lingual view; (10-12), MNA V11310, tooth, (10) labial view, (11) occlusal view, (12) mesial view. (13-15), Cooleyella fordi; MNA V11306, tooth, (13) labial view, (14) occlusal view, (15) mesial view. Scale bars $=200 \mu \mathrm{m}$.

tentative report of Cooleyella cf. C. fordi from the Cisuralian (early Permian) of the middle and south Urals of Russia (Duffin and Ward, 1983; Ivanov, 2005). The Surprise Canyon specimen is the first record of $C$. fordi for the Serpukhovian of North America.

Cooleyella platera new species

Figure 10.1-10.12
Diagnosis.-Small anachronistid neoselachian shark with monocuspid teeth $400-600 \mu \mathrm{m}$ long mesiodistally, 400 $700 \mu \mathrm{m}$ wide labiolingually, and $300-400 \mu \mathrm{m}$ tall. Crown smooth and ovate, overlapping basolabial projection, no discernable median cusp, lingually inclined. Tooth base composed of single short basalolabial projection and tall and mesiodistally wide lingual ridge, both structures separated by a deep and broad central pit. Lingual foramen or longitudinal groove present on lingual ridge. 
Occurrence.-Surprise Canyon Formation, lower and middle members, latest Mississippian (Serpukhovian), Burnt Springs Canyon location 6, concentration 1(MNA V11308 and MNA V11309); Blue Mountain Locality 3, section 2 (MNA V11307 and MNA V11310); Blue Mountain Locality 4, section 2 (MNA V11311).

Description.-Crown of Cooleyella platera n. sp. lacks definitive median cusp and is primarily circular or ovate with cutting edge present on lingual margin. Crown inclined labially, wide mesiodistally, moderately tall labiolingually. Labial surface of crown smooth, lacking marginal crests or ridges, and overlaps basolabial projection. Ventral margin of crown rounded mesiodistally. Tooth base comprises a single basolabial peg-like projection and wide transverse lingual basal ridge. Basolabial projection small, round, and positioned just linguad of the ventral labial margin of crown. Lingually projecting basal ridge less wide or as wide as crown and a single median labiolingual foramen or open median canal is present with the basal ridge. Deep central pit present between basolabial projection and lingual basal ridge.

Etymology.-Latin platera, a flat dish; in recognition of the crown's smooth, nearly circular, plate-like shape.

Material.-MNA V11308, tooth; MNA V11309, tooth; MNA V11310, tooth; MNA V11311, tooth.

Remarks.-The tooth base of C. platera $\mathrm{n}$. sp. is similar to the other Cooleyella species, C. peculiaris, C. fordi, and C. amazonensis Duffin, Richter, and Neis, 1996, and consists of a small basolabial projection that is present near the ventrolabial margin of the of the crown and a lingually projecting, mesiodistally wide, basal ridge with a single median foramen or canal present (Gunnel, 1933; Duffin and Ward, 1983; Duffin et al., 1996). Variability in the shape and size of the basolabial projection does occur in the known taxa because it is more triangular in $C$. fordi and rounded in $C$. amazonensis, $C$. peculiaris, and C. platera $\mathrm{n}$. sp. The rounded basolabial projection in $C$. peculiaris is proportionately larger than that seen in $C$. amazonensis and $C$. platera $\mathrm{n}$. $\mathrm{sp}$. (Hanson, 1986; Duffin et al., 1996; Ivanov, 2011). The lingual basal ridge is less broad mesiodistally in C. peculiaris, but is more mesiodistally expanded in C. fordi, C. amazonensis, and C. platera n. sp. (Duffin and Ward, 1983; Hansen, 1986; Duffin et al., 1996; Ivanov, 2011). The central pit in $C$. platera $\mathrm{n}$. sp. is relatively deep and enlarged in contrast to $C$. peculiaris, C. fordi, and C. amazonensis in which it is relatively shallow and small (Duffin and Ward, 1983; Hansen, 1986; Duffin et al., 1996; Ivanov, 2011). The crown of $C$. platera $\mathrm{n}$. sp. is the least developed of the Cooleyella species. In $C$. peculiaris, $C$. fordi, and $C$. amazonensis the crown has a median lingually directed cusp and lateral blade like cusps that are directed horizontally (C. peculiaris and C. amazonensis) or angled downward (C. fordi) mesiodistally (Duffin and Ward, 1983; Hansen, 1986; Duffin et al., 1996; Ivanov, 2011). Cooleyella platera $\mathrm{n}$. sp. is unique in lacking median and lateral cusps, but consists of a single circular or ovate cusp with a broad convex lingual cutting edge. The ventrolabial rim of the crown in C. platera n. sp. is broad and rounded mesiodistally, similar to that seen in $C$. peculiaris and $C$. amazonensis, and not narrow and pointed as in C. fordi (Duffin and Ward, 1983; Hansen, 1986; Duffin et al., 1996; Ivanov, 2011).

The distribution and diversity of the Anachronistidae show that this group is presently restricted to the Late Mississippian to late Permian (Ginter et al., 2010; Ivanov, 2011). At least five species of Cooleyella are presently recognized. The type species, C. peculiaris, is known from the Pennsylvanian (Missourian), Kansas City Group Winterset Limestone and Cherryvale Shale at Kansas City (Gunnel, 1933; Ginter et al., 2010); from the Pennsylvanian (Virgilian) Levenworth Limestone of Iowa, Kansas, Nebraska, and Oklahoma (Tway, 1982); the Virgilian Heebner Shale from Iowa, Kansas, Missiouri, Nebraska, and Oklahoma (Tway, 1982); the Virgilian Plattsmouth Limestone from Iowa, Kansas, Missiouri, Nebraska, and Oklahoma (Tway, 1982); and the Pennsylvanian Appalachian Group of Ohio (Hansen, 1986). Cooleyella fordi is one of the oldest Cooleyella species, known from the Visean of the Steeplehouse Quarry Derbyshire U.K. (Duffin and Ward, 1983) and the Serpukhovian Surprise Canyon Formation of the western Grand Canyon (this study). Although seemingly widely distributed in central North America, C. peculiaris has been little studied since the work by Gunnel (1933) and Hansen (1986) and needs review. Cooleyella amazonensis is known from the Early Pennsylvanian (Bashkirian/Moscovian) of the Itaituba Formation of the Amazon Basin, Brazil and the early Permian in the Urals of Russia (Ivanov, 2011). Ivanov (2011) recognized an undescribed new species from the middle Permian of western Texas previously referred to as Cooleyella sp. in Duffin and Ward (1983), which Ivanov et al. (2015) later named Cooleyella duffini Ivanov, Nestell, and Nestell, 2015. Cooleyella duffini differs from all other Cooleyella species in having a central cusp and two to four lateral cusplets on the occlusal crest and aserrated labial edge of the crown (Ivanov et al., 2015). Cooleyella platera $\mathrm{n}$. sp. is presently only known from the lower and middle members of the Serpukhovian Surprise Canyon of the western Grand Canyon.

Genus Amaradontus new genus

Type species.—Amaradontus santuccii $\mathrm{n}$. gen. $\mathrm{n}$. sp.

Diagnosis.-As for species, by monotypy.

Etymology.-Greek Amara, a ditch or channel, Greek odontos, tooth, in recognition of its occurrence in the ancient paleo-valleys of the Surprise Canyon Formation within the Grand Canyon.

Remarks.-See remarks for species.

Amaradontus santuccii new species Figure 11.1-11.17

Holotype.-Mediolateral tooth, MNA V11312. 


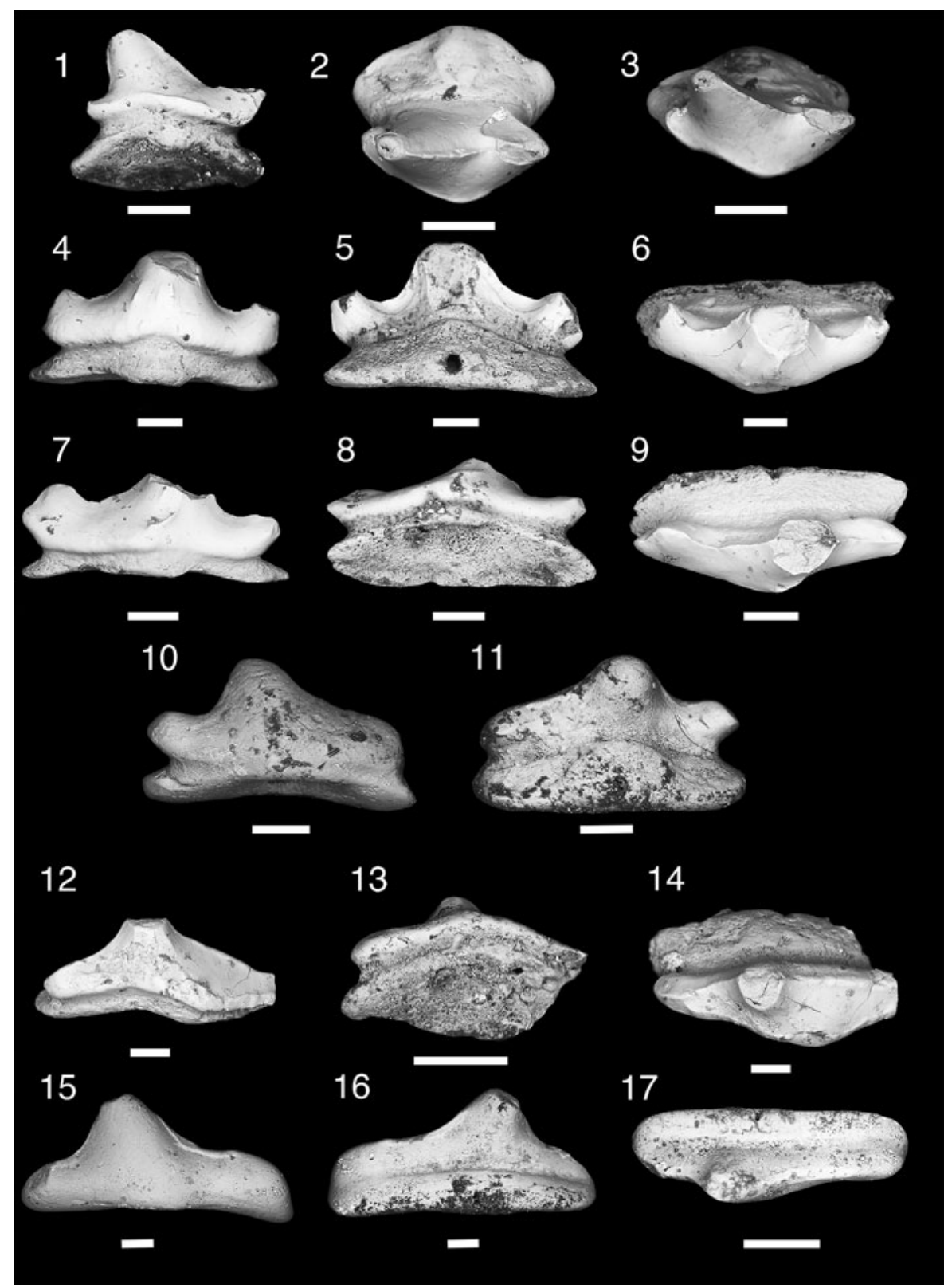

Figure 11. Teeth of Amaradontus santuccii n. gen. n. sp; (1-17), (1-3) MNA V11316, anterior tooth, (1) labial view, (2) occlusal-lingual view, (3) occlusal view; (4-6) MNA V11312, holotype, mediolateral tooth, (4) labial view, (5) lingual view, (6) occlusal view; (7-9) MNA V11317, lateral tooth, (7) labial view, (8) aboral view, (9) occlusal-lingual view; (10, 11) MNA V11315, lateral tooth, (10) labial, (11) lingual; (12-14) MNA V11313, posterior tooth, (12) labial view, (13) aboral view, (14) occlusal view; (15-17) MNA V11314, (15) labial view, (16) lingual view, (17) occlusal view. Scale bars = $200 \mu \mathrm{m}$.

Diagnosis.-Small anachronistid shark with heterodont teeth ranging from $\sim 600 \mu \mathrm{m}-1 \mathrm{~mm}$ mesiodistally to $\sim 400-500 \mu \mathrm{m}$ labiolingually, and an approximate height of $300-400 \mu \mathrm{m}$. Crown asymmetric. Median cusp broad mesiodistally, inclined distally, and with rounded apex. Lateral cusps low or absent. Cusps connected by sharp carinae. One to two vertical ridges can be present on median cusp. A faint labial cingulum present. Tooth base comprises an elliptical mesiodistally broad basolabial projection and lingually shallow mesiodistally wide basal ridge. Basolabial projection positioned under median cusp. Central pit shallow and wide mesiodistally. A single large circular foramen present on lingual margin of base exits labially.
Occurrence.-Surprise Canyon Formation, lower and middle members, latest Mississippian (Serpukhovian), Grand Canyon, Mohave County, Arizona, Burnt Springs Canyon location 6, concentration 1; Blue Mountain Locality 4, section 2, Bat Tower 2, sections 13 and 18 .

Description.-All teeth of Amaradontus santuccii n. gen. n. sp. exhibit asymmetric crowns. Median cusp broad mesiodistally, with rounded nearly blunt apex, and smooth carina on mesial and distal margins (Fig. 11.1-11.3). Median and lateral cusps inclined lingually over tooth base (Fig. 11.1-11.3). Mesial lateral cusp more elongated than distal lateral cusp. Mesial and distal lateral cusps of more anterior tooth families low but 
oriented vertically. Lateral cusps become steadily reduced in height posteriorly until completely lost and replaced by continuous mesiodistal carina in most posterior tooth families. Slight labial cingulum and faint vertical ridge can be present on crown. Lateral basal margin of crown does not extend below basolabial projection, but instead ends just above tooth base with nearly straight basal margin to crown. Tooth base lingually extended in anterior tooth families forming rounded lingual margin, which becomes progressively more compressed labiolingually and straight in more posterior tooth families (Fig. 11.2, 11.11). Single mesiodistally broad basolabial projection present and in line with midline of median cusp and labial margin of tooth base. Basolabial projection elliptical aborally, narrow labiolingually. Lingual basal ridge wider mesiodistally than crown and typically has a nearly straight lingual margin (with a few exceptions). Single large foramen present at midline of median cusp on lingual border of lingual basal ridge. Shallow, mesiodistally long, and labiolingually narrow aboral groove present with single median foramen. Anterior teeth overall tend to be less elongated mesiodistally and wider labiolingually. Lateral and posterior teeth more elongated mesiodistally and wider labiolingually.

Etymology.-In honor of Vincent Santucci in recognition of his services to the National Park Service and to NPS paleontology.

Material.-MNA V11313, lateral tooth; MNA V11314, lateral tooth; MNA V11315; lateral tooth; MNA V11316, anterior tooth; MNA V11317, mediolateral tooth.

Remarks.-Ivanov et al. (2014) were the first to report a new, but unnamed, anachronistid neoselachian shark from the Serpukhovian of the Moscow region. This taxon, like Amaradontus santuccii n. gen. n. sp. differs from Cooleyella in having a crown that is more compressed labiolingually, with well-developed median and lateral cusps. The basal labial rim does not extend over the basolabial projection, the tooth base is elongated mesiodistally and wider than the crown, and a more reduced lingual basal ridge is present. Amaradontus santuccii n. gen. n. sp., however, is not the same genus as the taxon from the Moscow syneclise, differing in having a more asymmetric crown in which the mesial lateral cusp is longer than the distal lateral cusp and the median and lateral cusps are broader mesiodistally and blunter. The lateral cusps are less tall and well developed and posteriorly become reduced until finally being lost in Amaradontus n. gen., while in the Moscow taxon all teeth have well-developed lateral cusps for each tooth family. In Amaradontus n. gen. the basolabial projection is in line with the labial margin of the tooth base, although in the Moscow taxon the basolabial projection is positioned forward of the labial margin of the tooth base. Clearly the Moscow taxon and A. santuccii n. gen. n. sp. represent a new subfamily within the Anachronistidae (A. Ivanov, personal communication, 2015) with A. santuccii n. gen. n. sp. being the most heterodont of the two taxa. However, defining this new subfamily and its significance is beyond the scope of this paper. A more thorough review of the Anachronistidae is needed in light of the new taxa described here, together with other recently described forms
(Duffin and Ward, 1983; Duffin et al., 1996; Duffin and Ivanov, 2008; Ivanov, 2011; Ivanov et al., 2014).

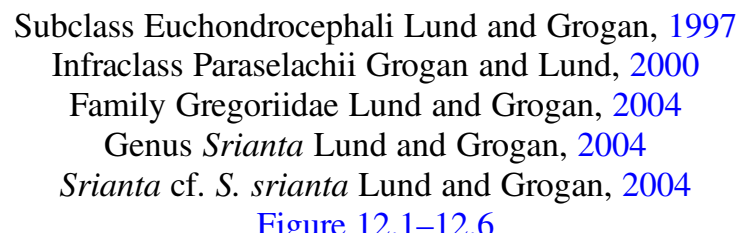

Occurrence.-Surprise Canyon Formation, middle and upper member, latest Mississippian (Serpukhovian), Bat Tower Locality 2, sections 13 and 26.

Description.-Two teeth missing distal portion of tooth base. Labiolingually compressed crowns consist of a low central cusp with three minute lateral cusps in a mesiodistally directed arch (Fig. 12.1, 12.2). Prominent basal, labially projecting boss present, positioned on midline of central cusp with thick longitudinal crest extending towards central cusp apex (Fig. 12.1, 12.4). Approximately 13 or 14 additional thin longitudinal crests present on lingual surface of crown. Well-developed cingulum present along lower margin of labial and lingual sides of crown, just above tooth base. Tooth base in both specimens incomplete, but indicates it was elongated, labiolingually compressed, and directed downwards. Thin longitudinal elliptical foramina present on labiolingual surface of tooth base.

\section{Material._-Teeth: MNA V11318, MNA V11319.}

Remarks. - The teeth described here are the first evidence of a gregoriid chondrichthyan, specifically the genus Srianta, outside the Bear Gulch fauna. Lund and Grogan (2004) established this taxon based on three genera (Gregorius, Bealbonn, and Srianta), which share autodiastylic suspensoria, a protacrodont-like squamation, teeth with fluted crowns with a single basal ridge in the upper and lower jaws, presence of a symphysial and parasymphysial dentition composed of single conical cusps lacking basal ridges and having a remote narrow anal fin. The Surprise Canyon specimens' best match Srianta, the teeth of which have low central cusps with three to four lateral cusps that bear transverse crests, and a prominent basal ridge on the labiolingual margins of the crown (Lund and Grogan, 2004). We tentatively place these teeth as Srianta $\mathrm{cf}$. $S$. srianta, based on a labially projecting boss present on the lower teeth, a feature seemingly lacking in S. iarlais Lund and Grogan, 2004 and S. dawsoni Lund and Grogan, 2004 (Lund and Grogan, 2004). These teeth were collected from the upper section of the middle member and the lower section of the upper member of the Surprise Canyon Formation at the Bat Tower locality 2 type section.

\section{Family Debeeriidae Grogan and Lund, 2000 Genus Heteropetalus Lund, 1977 Heteropetalus sp. Figure 12.7-12.11}

Occurrence.-Surprise Canyon Formation, lower/middle member, latest Mississippian (Serpukhovian), Burnt Springs Canyon locality 6, concentration 1 . 


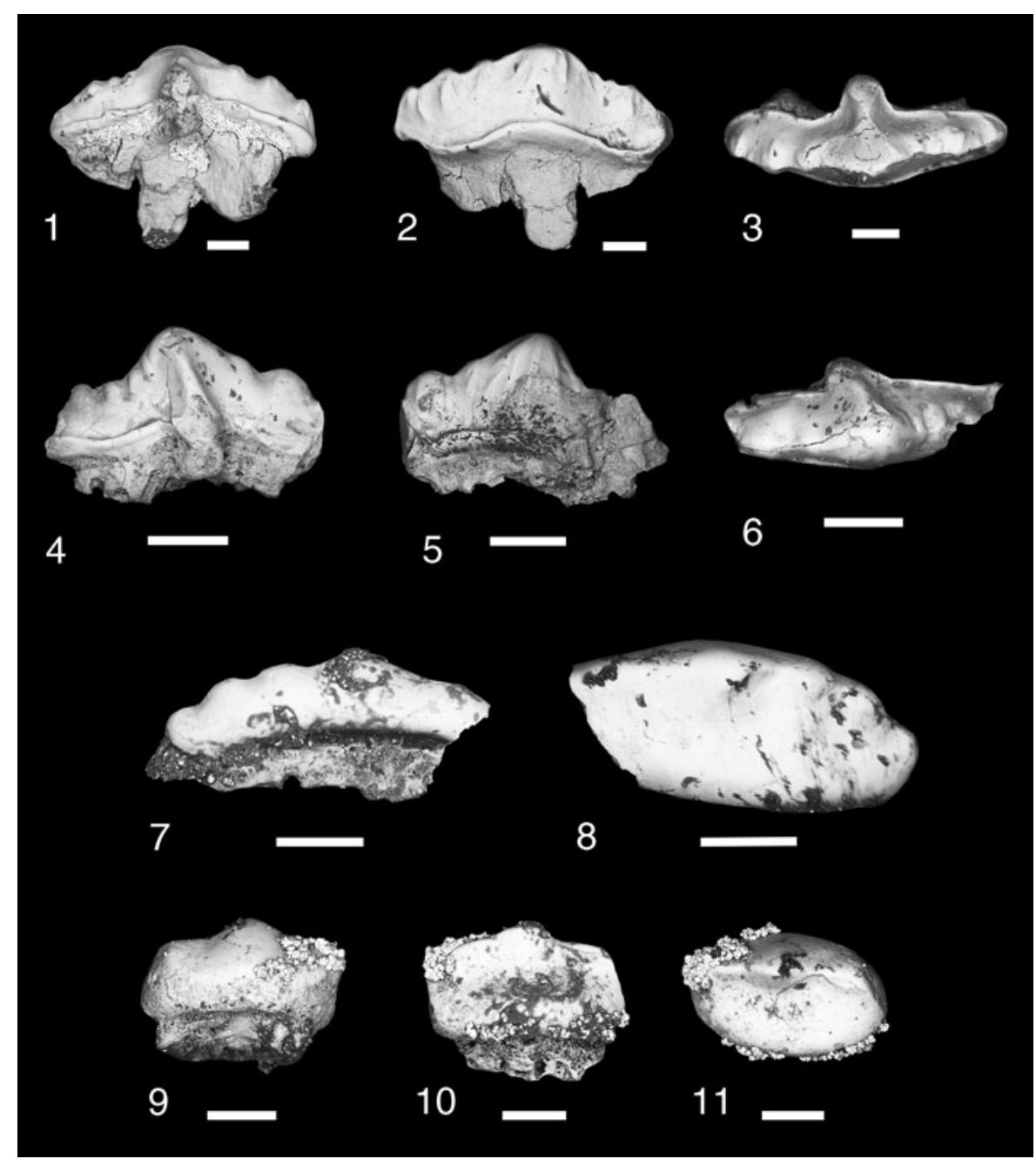

Figure 12. Teeth of Euchondrocephali; Paraselachii. (1-6) Srianta cf. S. srianta; (1-3), MNA V11318, tooth, (1) lingual view, (2) labial view, (3) occlusal view; (4-6), MNA V11319, tooth, (4) lingual view, (5) labial view, (6) occlusal view. (7-11) Heteropetalus sp.; (7, 8) MNA V11320, tooth, (7) labial view, (8) occlusal view; (9-11) MNA V11321, tooth, (9) labial view, (10) lingual view, (11) occlusal view. Scale bars $=500 \mu \mathrm{m}$.

Description.-Two teeth with distal tooth base missing and representing anterior and lateral positions. Crowns of both teeth share slightly taller median than lateral cusps, basal portion of crown slightly concave and expanded into basin-like lingual margin, labial margin short and convex. Basolingual margins in both teeth U-shaped, narrow and slightly arched. Anterior tooth has single median cusp with single horizontal chisel-like lateral cusp on either side. Lateral tooth missing a third of the crown, but enough remains to show that it had a low median cusp and at least three low and blunt lateral cusps (Fig. 12.7). Tooth base, though mostly missing, compressed labiolingually and projected aborally.

\section{Material.-Teeth: MNA V11320, MNA V11321.}

Remarks.-These teeth represent the first record of Heteropetalus outside the Bear Gulch fauna of Montana. However, due to the incomplete nature of the dentition we cannot confidently place these teeth above the generic level until more specimens are available for comparison. The teeth of Heteropetalus differ from the other debeerid chondrichthyan, Debeerius ellefseni Grogan and Lund, 2000 in having crowns with more well defined and numerous cusps and a U-shaped lingual basal margin, while in D. ellefseni, the crown either lacks defined cusps or they are slight and have a V-shaped basal lingual margin (Lund, 1977; Grogan and Lund, 2000). Superficially, debeerid teeth look similar to gregoriid teeth but differ in the presence of a well-developed basal cingulum around the labial and lingual margins of the crown, which gregoriids have and debeerids lack (Lund, 1977; Grogan and Lund, 2000; Lund and Grogan, 2004). The Surprise Canyon specimens of Heteropetalus have thus far only been collected from the lower member of the Burnt Springs Canyon Locality 6.

Order Orodontiformes Zangerl, 1981

Family Orodontidae De Konnick 1878

Genus and species indeterminate

Figure 13.8-13.10

Occurrence.-Surprise Canyon Formation, lower/middle member, latest Mississippian (Serpukhovian), Burnt Springs Canyon locality 6 , concentration 1 . 


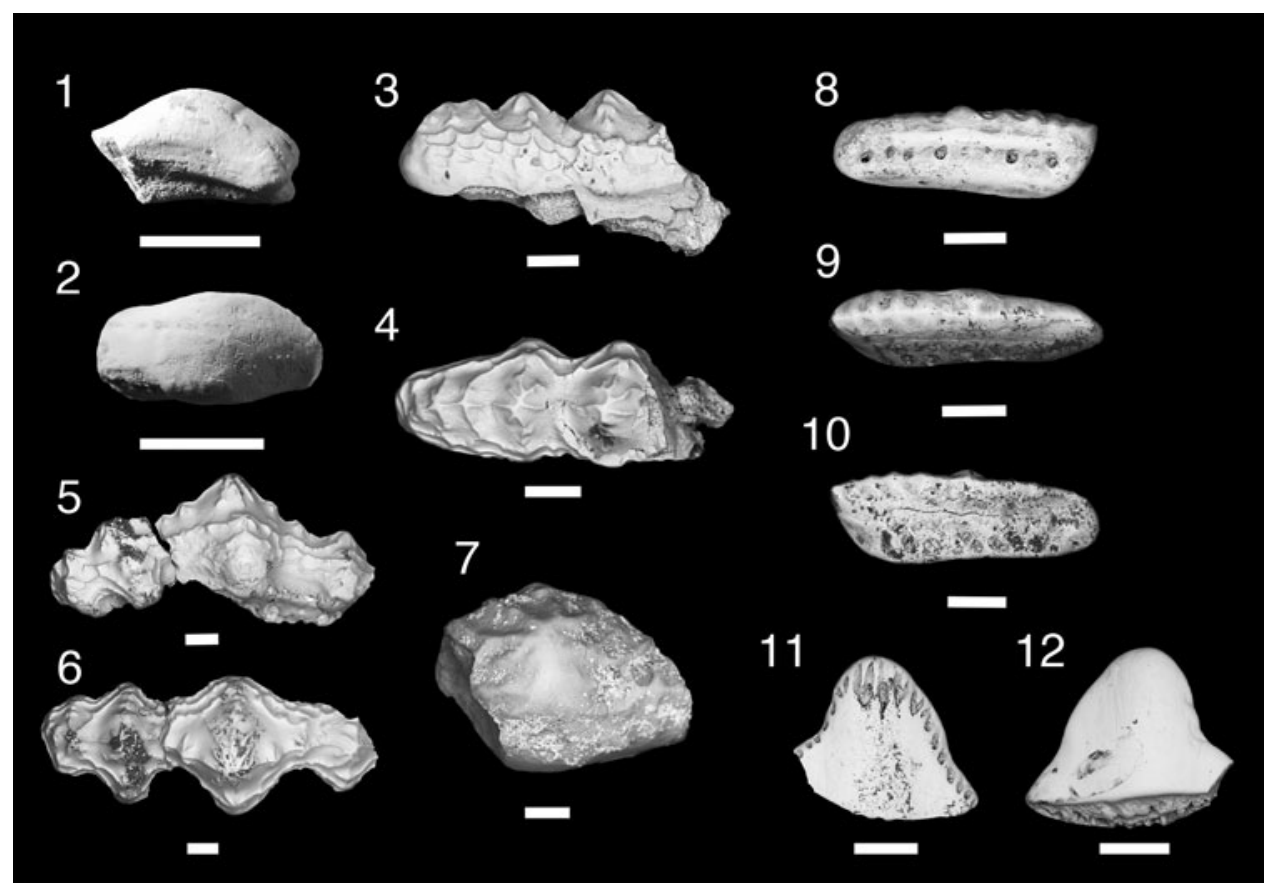

Figure 13. Teeth of Euchondrocephali; Helododontiformes, Eugenodontiformes, Orodontiformes, and Petalodontiformes. (1, 2) Helodus? sp., USNM PAL 603799 tooth, (1) labial view, (2) occlusal view. (3-7) Eugeneodontiformes genus and species indeterminate, (3, 4) MNA V11325, tooth, (3) lingual view, (4) occlusal view; (5, 6) MNA V11324, tooth, (5) labial view, (6) occlusal view; MNA V11323, tooth fragment, (7) occlusal view. (8-10) Orodontiformes genus and species indeterminate, MNA V11322, tooth, (8) labial-aboral view, (9) occlusal view, (10) lingual view. (11, 12) Petalodontiformes genus and species indeterminate, MNA V11326, tooth, (11) lingual view, (12) labial view. Scale bars $=1 \mathrm{~cm}(\mathbf{1}, \mathbf{2}) ; 500 \mu \mathrm{m}(\mathbf{3}-\mathbf{1 2})$.

Description.-A single complete lateral tooth $\sim 2 \mathrm{~mm}$ mesiodistally, $500 \mu \mathrm{m}$ labiolingually, and $600 \mu \mathrm{m}$ tall. Mesiodistally elongated and narrows labiolingually. Crown is low with small median cusp, slightly higher than lateral cusps. Median cusp narrow labiolingually forming a small domed peak. Approximately five very low lateral cusps with transverse ridges extending to basal rim of crown. Slight median mesiodistal crest present on crown. Tooth base taller than crown and directed aborally. Nine labial foramina present in a shallow mesiodistal groove. Lingual margin of tooth base flat with nine foramina present.

\section{Material.-Tooth: MNA V11322.}

Remarks.-The orodont specimen from the Surprise Canyon Formation is nearly identical to "Orodus sp." specimens described by Elliott et al. (2004) from the Middle Pennsylvanian (Desmoinesian) Naco Formation of central Arizona. The Surprise Canyon taxon and the Naco taxon both share a mesiodistally elongated crown that is narrow labiolingually, a tall median cusp with five to seven lateral cusps with transverse ridges, the tooth base taller than the crown, and a labial mesiodistal basal groove with numerous foramina in a single row. Elliott et al. (2004) suggested the Naco teeth resembled the teeth of Orodus greggi Zangerl, 1981, which is known from a large partial but articulated specimen from the Middle Pennsylvanian (Desmoinesian) Logan Quarry shale of Indiana (Zangerl, 1981). The Orodontiformes has been argued to be an artificial grouping that needs revision (Ginter et al., 2010). The Surprise Canyon and Naco specimens differ from the type material of Orodus and as such we feel these specimens are probably not Orodus sensu lato. However, along with "O." greggi, these specimens most likely represent an orodontid group closely related to Orodus.

Order Eugeneodontiformes Zangerl, 1981

Superfamily Caseodontoidea Zangerl, 1981

Family uncertain

Genus and species indeterminate

Figure 13.3-13.7

Occurrence.-Surprise Canyon Formation, middle member; latest Mississippian (Serpukhovian); Blue Mountain Canyon locality 3, section 2; Bat Tower Locality 2, section 13.

Description.-Three partial lateral pavement teeth lacking tooth bases, measuring between $800 \mu \mathrm{m}$ and $1 \mathrm{~mm}$ mesiodistally. Crown slightly arched orally, mesiodistally elongated, and narrow labiolingually. Median cusp conical with slightly crenulated labiolingual crest on apex of cusp. Lateral cusps small relative to median cusp, and have labiolingual crests with crenulated ornamentation (Fig. 13.5, 13.6). Two to three cingulum-like crenulated ridges present on the labial and lingual margins of crown. Labial and lingual bosses present in line with median and lateral cusps with labial bosses more prominent than lingual bosses.

Material.-Teeth: MNA V11323, MNA V11324, MNA V11325. 
Remarks.-These teeth are superficially similar to some orodont dentitions, like that seen in the Orodus mammillaris Newberry and Worthen, 1866 group (Ginter et al., 2010), which have enlarged circular median cusps and can have less prominent lateral cusps or cusplets. However, the Surprise Canyon taxon has well-developed labial and lingual projections and labiolingually directed crests that extend over the apices of each cusp, a feature lacking in orodont dentitions but prominent in the lateral pavement teeth of caseodontid eugenodonts (Ginter et al., 2010). Ginter et al. (2010) did remark that the distinction between orodont and eugenodont dentitions is a matter of arbitrary and intuitive opinion. We feel that these teeth fall within the parameters of a caseodontid eugeneodont due to the presence of sharply defined transverse (labiolingual) ridges, which have secondary crenulations that are separated by deep excavations (Ginter et al., 2010).

The record of eugeneodont sharks primarily extends through the Pennsylvanian and Permian (Zangerl, 1981; Ginter et al., 2010). The earliest record of a eugeneodont shark is based on the lateral pavement dentition of Campodus agassizianus De Koninck, 1844, a caseodontid eugeneodont, that has been recognized from the latest Mississippian (Serpukhovian) of Belgium and Missouri, USA (Zangerl, 1981; Ginter et al., 2010). A second slightly younger taxon, Chiastodus obvallatus Trautschold, 1879, from the Mississippian/Pennsylvanian of Moscow is based on a single symphysial tooth (Ginter et al., 2010), and therefore not valuable for comparison here. Zangerl (1981) had suggested, however, that Chiastodus might be a synonym of Campodus. The Surprise Canyon taxon has a few similarities to Campodus including the presence of labial and lingual bosses and an orally arched crown. However, the Surprise Canyon taxon differs from Campodus in having the labiolingual crests not extending to the basal margins of the crown, more conical median and lateral cusps, and the presence of two to three labial and lingual crenulations. We suggest that the Surprise Canyon taxon represents the newest example of a small Late Mississippian caseodontid eugeneodont shark.

\section{Order Petalodontiformes Zangerl, 1981 Family uncertain \\ Genus and species indeterminate Figure 13.11, 13.12}

Occurrence.-Surprise Canyon Formation; middle member; latest Mississippian (Serpukhovian); Bat Tower Locality 2, sections 13

Description.-A single tooth fragment consisting of a labiolingually compressed asymmetric triangular cusp. The mesiodistal carina is smooth. The labial edge of the carina has a series of vertical elliptical openings. The tooth base is missing.

\section{Material.-Tooth fragment: MNA V11326.}

Remarks. - This is the only record of a petalodont from the Surprise Canyon Formation. The tooth fragment consists of a labiolingually flattened cusp with an asymmetric, triangular tip. The asymmetric nature of this tooth fragment eliminates petalodont taxa that tend to have symmetrical crowns in all tooth families such as Petalodus, Belantsea, and Polyrhizodus (Lund, 1983, 1989; Ginter et al., 2010), or symmetric upper symphysial teeth as in Petalorhynchus, Siksika, Orbuchevodus, Fissodopsis, and Netsepoye (Lund, 1989; Grogan et al., 2014; Lund et al., 2014). This fragment could represent the lower Fissodus-like symphysial tooth morph, recently recognized in a majority of petalodonts from Bear Gulch, which consists of a bifurcated and mesiodistally expanded crown (Lund et al., 2014). The lack of crenulations on the crown, a feature that is present in Siksika and Orbuchevodus, suggests a closer relationship to Fissodopsis, Netsepoye, or Petalorhynchus (Lund et al., 2014). However, the fragmentary nature of the specimen leaves a generic assignment ambiguous at best.

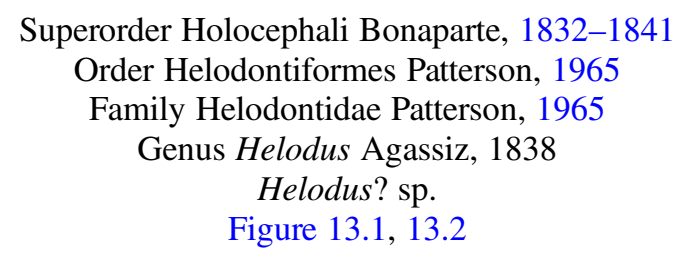

Occurrence.-Surprise Canyon Formation, upper member, latest Mississippian (Serpukhovian); West Stairway Canyon, (Unit 3).

Description.-A single tooth, weathered free of matrix and missing a small portion at one end. Small (length as preserved $8.8 \mathrm{~mm}$; width $4.7 \mathrm{~mm}$; height $4.7 \mathrm{~mm}$ ), and consists of a tumid crown and narrow base. Tooth elongated mesiodistally, crown in oral view has somewhat convex lateral margins, a truncated termination, and is surmounted at the midpoint by a rounded crown. Crown has a smooth surface and numerous small vascular channels visible penetrating the worn surface and producing a characteristic punctate pattern.

Root is narrow ( $2.0 \mathrm{~mm}$ wide) and projects slightly at undamaged end of tooth where it terminates in a rounded point. Consists of thin basal plate with smooth, slightly concave, base separated from the crown by a narrow groove on both sides. Root slightly worn but shows a series of small, evenly spaced foramina along its length on both sides.

\section{Material.-Tooth: USNM PAL 603799.}

Remarks.-This genus is known from several incomplete skeletons and many isolated teeth (Stahl, 1999). Moy-Thomas (1936) described and reconstructed the type species (H. simplex), and the dentition is only known in its entirety from this species. As reconstructed it consists of a series of eight or nine tooth families along each jaw ramus with four or five tooth crowns visible in each family. The teeth tend to be smaller at the mesial and distal ends of the series than in the center where the teeth are fused into plates (Stahl, 1999). Many Helodus species are based on isolated teeth and because the dentition is composed of diverse elements, as shown by the presence of several different species of Helodus tooth in an associated dentition of Psephodus (Traquair, 1885), it is probable that the number of species is exaggerated. 
The genus is known worldwide from the Late Devonian to the early Permian, but is particularly common in the upper Carboniferous of the British Isles (McCoy, 1855; Morris and Roberts, 1862; Ward, 1875), the lower Carboniferous of Belgium (De Koninck, 1878) and northern France (Pruvost, 1919), and the lower Carboniferous of Midwestern USA (Newberry and Worthen, 1866; St. John and Worthen, 1875; Newberry, 1879).

Order Cochliodontiformes Obruchev, 1953

Family Cochliodontidae Owen, 1867

Genus Cochliodus Agassiz, 1838

Cochliodus cf. C. contortus Newberry and Worthen, 1870

Figure 14.1, 14.2

Occurrence.-Surprise Canyon Formation, middle unit; latest Mississippian (Serpukhovian); Rampart Cave Section.
Description.-Single large right anterior dental plate $(32.0 \mathrm{~mm}$ along the radial axis), strongly curved, convex on occlusal surface and with a high, narrow, ridge along the radial axis. Distal to the ridge is a deep groove, bordered on the distal margin by a low, rounded, ridge. Mesial margin slightly broken and junction between the labial and mesial edges is incomplete.

Material._-Tooth plate: USNM PAL 412147.

Remarks. - Cochliodontid holocephalans bore convoluted dental plates on the lower jaw, a larger posterior and smaller anterior, that occluded with a single pair of more elongated plates mounted to the undersurface of the neurocranium. Anterior to the upper plates were at least two series of helodontid teeth (Stahl, 1999). The larger posterior teeth were broad but narrow anteroposteriorly. This dental plate appears to have been an anterior plate from the right side of the lower jaw.

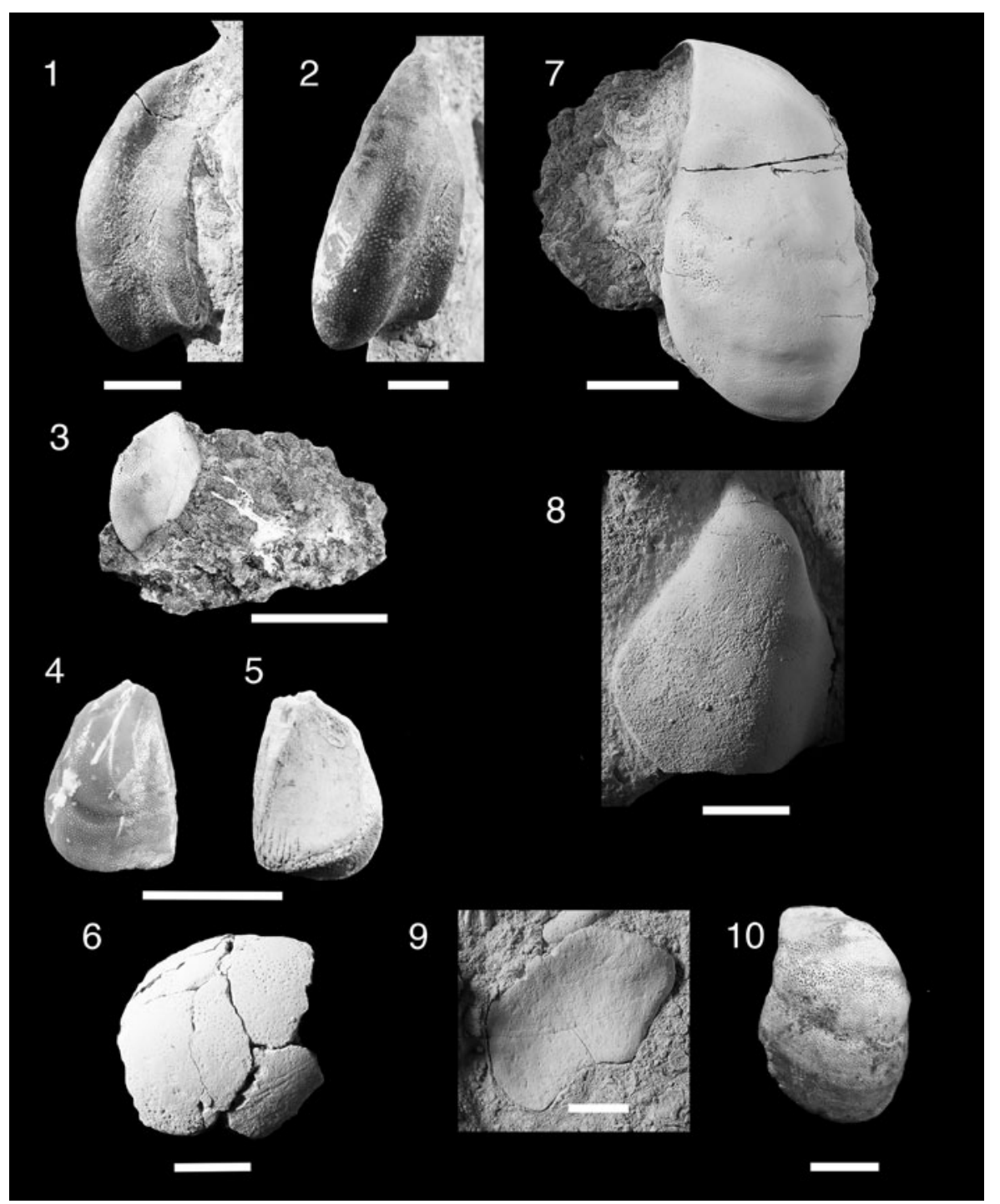

Figure 14. Teeth of Euchondrocephali; Holocephali. $(\mathbf{1}, \mathbf{2})$ Cochliodus cf. C. contortus; $(\mathbf{1}, \mathbf{2})$ USNM PAL 412147 anterior right dental plate, (1) labial view, (2) occlusal view. (3-6) Deltodus cf. D. angularis; (3) USNM PAL 412168 anterior mandibular dental plate in occlusial view, (4, 5) USNM PAL 603798 posterior mandibular dental plate, (4) occlusal view, (5) aboral view; (6) USNM PAL 412170 upper jaw dental plate in occlusial view. (7, 8) Deltodus cf. D. cingulatus; (7) USNM PAL 412146 right mandibular dental plates in occlusal view, (8) USNM PAL 412148 right mandibular dental plate in occlusal view. (9, 10) Deltodus sp.; (9) USNM PAL 4121773 upper dental plate in aboral view, (10) USNM PAL 412145 upper dental plate in occlusal view. Scale bars $=1 \mathrm{~cm}$. 
Although mainly reported from the lower Carboniferous of Ireland, Belgium, and England (Stahl, 1999), an isolated lower jaw of this species has also been described from the lower Carboniferous (Serpukhovian) Bear Gulch Limestone of Montana (Lund and Grogan, 1997).

Genus Deltodus Morris and Roberts, 1862

(ex Agassiz Ms., 1859)

Deltodus cf. D. angularis Newberry and Worthen, 1866

Figure 14.3-14.6

Occurrence.-Surprise Canyon Formation; Travertine Canyon, lower member; (USNM PAL 412170, 603798); Stairway Canyon, upper member; (USNM PAL 412168); latest Mississippian (Serpukhovian).

Description.-Three specimens are attributed to this species. USNM PAL 412168 (Fig. 14.3) is an incomplete, small, anterior mandibular dental plate with a convex occlusal surface; oval in outline, $10 \mathrm{~mm}$ long and $5.8 \mathrm{~mm}$ wide. USNM PAL 603798 (Fig. 14.4, 14.5) is a small, posterior, mandibular tooth, roughly triangular with part of the anterior point missing, and is $12.4 \mathrm{~mm}$ long and $8.9 \mathrm{~mm}$ wide. A broad, convex ridge is present along the mesial edge of the dental plate and this broadens to form much of the lingual edge. Distally a trough starts near the anterior edge and broadens and shallows towards the lingual edge. USNM PAL 412170 (Fig. 14.6) is a large, thickened dental fragment that probably formed part of an upper jaw dental plate.

Material.-Anterior mandibular dental plate: USNM PAL 412168; posterior mandibular dental plate: USNM PAL 603798; upper jaw dental plate fragment: USNM PAL 412170.

Remarks.-Stahl and Hansen (2000) described an associated dentition of Deltodus angularis from the upper Carboniferous of Ohio. They showed that the lower jaw had two small anterior plates on either side of the symphysis, and that behind these on each side was a larger triangular posterior plate with a trough and ridge that occluded with the upper jaw dental plate. In the upper jaw was a single large plate on each side with a labial ridge that occluded with the trough in the posterior mandibular plate.

This species has been reported from several U.S. localities, including Illinois (Newberry and Worthen, 1866), Ohio (Stahl and Hansen, 2000), West Virginia (Lund et al., 1979), Colorado (Lockley, 1984), and Arizona (Elliott et al., 2004).

Deltodus cf. D. cingulatus Newberry and Worthen, 1866 Figure 14.7, 14.8

Occurrence.-Surprise Canyon Formation, Granite Park Section 2, lower member (USNM PAL 412148), and Rampart Cave Section, lower member (USNM PAL 412146); latest Mississippian (Serpukhovian).

Description.-Both specimens appear to be tooth plates from the lower jaw on the right side. The larger and more complete specimen (USNM PAL 412146; Fig. 14.7) is an elongated
(38.9 mm long) crushing tooth, curved, with a prominent convex ridge along the radial axis that is broadest at the lingual margin. The ridge narrows as it arches towards the labial margin and ends in an acute angle. Tooth is broken along the distal margin and is missing the furrow that broadens into a wing in complete specimens. Convex occlusal surface is marked by a series of ridges and furrows that cross it parallel to lingual margin of the plate. The second specimen (USNM PAL 412148; Fig. 14.8) is smaller than the first (26.0 mm long), but shows a similar morphology. The distal furrow and wing are broken away and the occlusal surface is marked by a series of ridges and grooves.

Material.-Two right mandibular tooth plates: USNM PAL 412146, USNM PAL 412148.

Remarks. - The holotype of D. cingulatus is a single tooth collected by Orestes St. John from the Mississipian Chester Limestone of Illinois, and described by Newberry and Worthen (1866, p. 99, pl. 9, fig. 6). Although many of the speciemens described in Newberry and Worthen (1866) found their way to the Smithsonian Insitution Paleobiology collections, the current whereabouts of the holotype of D. cingulatus is unknown. Croneis (1927) erected a pleisotype to D. cingulatus (MCZ 5322) from the Chesterian (Serpukhovian) Fayetteville Formation.

Deltodus sp.

Figure 14.9, 14.10

Occurrence.-Surprise Canyon Formation, middle member, West Stairway Canyon; latest Mississippian (Serpukhovian); lower Watahomigi Formation, Three Springs Canyon, Lower Pennsylvanian (Bashkirian).

Description.-Large tooth plate (USNM PAL 4121773; Fig. 14.9) in aboral view showing a slightly concave surface; $25.5 \mathrm{~mm}$ long and $16.0 \mathrm{~mm}$ wide with a roughly pentagonal outline. Based on the shape and on the thickened (labial) edge thinning lingually, this is probably an upper jaw tooth plate. Because it is only preserved in aboral aspect, it is not possible to identify it further. A series of smaller tooth plate fragments (USNM PAL 412174) were also collected from the Surprise Canyon Formation. A second upper tooth plate (USNM PAL 412145; Fig. 14.10) was collected from the Watahomigi Formation. This specimen measures $\sim 30 \mathrm{~mm}$ long and $25 \mathrm{~mm}$ wide.

Material.-Tooth plate: USNM PAL 412173; three tooth fragments: USNM PAL 412174; upper tooth plate: USNM PAL 412145.

Remarks.-McKee (1982) also listed the isolated teeth of "Deltodus" occurring in the Watahomigi Formation in the Grand Canyon from Guano Cave, Parashant Canyon and Separation Canyon. Unfortunately these specimens cannot be located, therefore the identifications of these records cannot substantiated. 
Subclass Elasmobranchii Bonaparte, 1838

Order, Family indeterminate

Genus Amelacanthus Maisey, 1982b

Amelacanthus sp.

Figure 15.1

Occurrence.-Surprise Canyon Formation, lower member, Quartermaster Canyon, section 2. Latest Mississippian (Serpukhovian).

Description.-Fin spine fragment $24.8 \mathrm{~mm}$ long and $5.8 \mathrm{~mm}$ wide, with four broad rounded ridges extending the length of the fragment and separated by intercostal grooves. One ridge forms the anterior margin of the spine and is the broadest (1.2 $\mathrm{mm}$ wide), while the most posterior spine is the narrowest $(0.8 \mathrm{~mm}$ wide). The ridges are smoothly rounded with a shiny enameled layer over the surface and with coarsely and irregularly crenulated edges.

Material.—Fin spine fragment: USNM PAL 412150.

Remarks. - Although this is a small fragment, the characteristic smooth ribs with a shiny enameloid surface layer are characteristic of Amelacanthus. Maisey (1982b) described this genus and included four species from the British lower Carboniferous. This genus was subsequently identified from the Pennsylvanian of Nebraska (Maisey, 1983), where it was associated with spines of Acondylacanthus, Bythiacanthus, and 'Physonemus.' It was also recognized in the Naco Formation of central Arizona (Elliott et al., 2004), where it was also associated with fin spines of Acondylacanthus. Separation into species is based on the number and size of the ribs and the pattern of bifurcation, but the fragment described here is too small to show those features.

\section{Genus Acondylacanthus St. John and Worthen, 1875 Acondylacanthus sp.}

Figure 15.2

Occurrence.-Surprise Canyon Formation, lower member, Granite Park, section 2. Latest Mississippian (Serpukhovian).

Description.-Poorly preserved fin spine fragment, broken at both ends and with most of the bone removed by weathering. Total length $118 \mathrm{~mm}$, width $19.5 \mathrm{~mm}$; specimen has a slight longitudinal curve. One short section ( $32 \mathrm{~mm}$ long) shows an

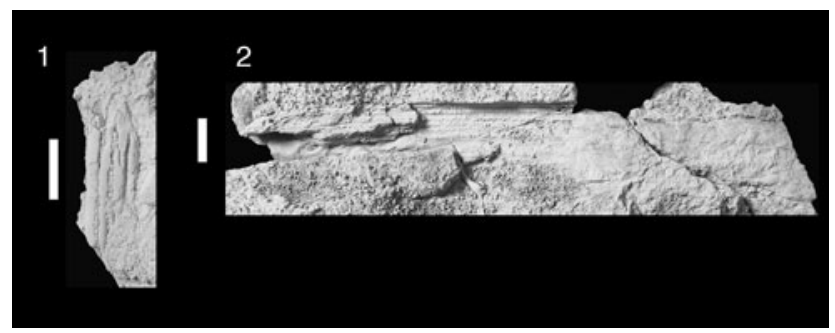

Figure 15. Chondrichthyan dermal spines from the Surprise Canyon Formation. (1) Amelacanthus sp. USNM PAL 412150 spine fragment in matrix; (2) Acondylacanthus sp., USNM PAL 412149 large spine fragment in matrix. Scale bars $=1 \mathrm{~cm}$. external impression with longitudinal ridges $1.0-1.5 \mathrm{~mm}$ wide. Ridges are broadly rounded, not bifurcating, and do not have denticulate margins. The convex (presumed anterior) margin is broadly rounded and composed of several ridges.

Material._Fin spine fragment: USNM PAL 412149.

Remarks.-This genus is recognized by its smooth, parallel, rounded ribbing. Separation into species rests on crosssectional shape, which is not preserved in this specimen. Acondylacanthus is known from Ohio (Hansen, 1986, 1996), Iowa (St. John and Worthen, 1875), Colorado (Itano et al., 2003), and Arizona (Elliott et al., 2004).

\section{Discussion of ecology and environmental preferences of the chondrichthyans of the Surprise Canyon and Watahomigi formations and their global relationships}

Assemblage structure of the Surprise Canyon Formation chondrichthyans.-The sharks of the Surprise Canyon Formation were diverse and distributed through many of the paleovalleys during the west to east marine transgression and periods of fluvial deposition. It should be stated that much of the material presented here was the byproduct of conodont studies (Martin, 1992; Martin and Barrick, 1999) or fortuitous recovery during the 1980 s field surveys measuring the geologic sections of the Surprise Canyon Formation (Billingsley et al., 1999). This method of collecting the vertebrate material may have skewed the natural composition of the Surprise Canyon shark assemblage because looking for vertebrate remains was not the priority of the research. However, due to the meticulous stratigraphic and biogeographic data that were recorded for the Surprise Canyon Formation (Billingsley and Beus, 1999b, appendices 1-3; Billingsley et al., 1999; Martin and Barrick, 1999), the following observations can be made for the Surprise Canyon shark assemblage:

Presence of holocephalan chondrichthyans in fluvial/ estuarine systems of the lower member of the Surprise Canyon Formation.-Holocephalan dental plates are the most common of the macro-chondrichthyan fossil material collected from the Surprise Canyon Formation, with the majority of them collected from the fluvial lower member siltstone, sandstone, and conglomerate beds. These dental plates show little to no wear that would indicate transportation or re-working (Irmis and Elliott, 2006). This suggests that these holocephalans were possibly inhabiting estuarine and fluvial environments during the beginning of Surprise Canyon deposition. Living holocephalans primarily occur in deeper marine habitats, although there are a few records of holocephalans occurring in esturaries (Bigelow and Schroeder, 1953). Fossil evidence of holocephalans occurring in nonmarine habitats is rare. A holocephalan within an estuarine system is known from a complete specimen from the upper Pennsylvanian Tijearas member of the Atrasado Formation of central New Mexico (Hodnett and Lucas, 2015). The new specimens from the lower member of the Surprise Canyon Formation, as well as other materials elsewhere, suggest that perhaps upper Paleozoic holocephalans had a wider 
range of salinity tolerance and environmental preferences than their modern descendents.

West to east distinction in the falcatid chondrichthyans in the middle member.-Three falcatid symmoriform chondrichthyians are presently known from the middle member of the Surprise Canyon Formation. Of these three, Denaea williamsi and "falcatid indet 1" are known from a substantial number of teeth from the stratigraphic samples made by Martin (1992). What is clear is that there was a west to east distinction for the distribution of these two forms. Falcatid indet 1 is presently only known from the Bat Tower type section at section 15 for the Surprise Canyon Formation, which at the time of deposition was closer to the development of the deeper open-water portion of the Surprise Canyon embayment. Teeth of $D$. williamsi are known from the Bat Tower type section, but only from two teeth collected from section 13, a slightly shallower depositional setting. The majority of the specimens of $D$. williamsi were collected from the eastern Blue Mountain Canyon sections, which represent shallower near shore environments.

Lund et al. $(2012,2015)$ demonstrated that the fishes of the Bear Gulch limestone had distinct distribution patterns within the embayment due to regional environmental conditions and the corresponding ecomorphological changes. Of interest here is that the stethacanthoid taxa of the Bear Gulch fish assemblage as a whole had a fairly even distribution throughout the embayment, but Lund et al. $(2012,2015)$ noted that Falcatus was more common in the marginal, bay mouth/basin and reef habitat zones, while Damocles and "other paleoselachii" were more common in the upper bay habitat zone.

Euselachian diversity.-The diversity of euselachian grade taxa within the Surprise Canyon Formation assemblage is relatively high. At present, six distinct tooth taxa are known from the Surprise Canyon Formation, primarily from the near shore deposits of the lower/middle member transition at Burnt Spings Canyon, the shallow Blue Mountain Canyon section, and the deeper Bat Tower 2 section of the middle members. Of these six taxa, Microklomax carrieae n. gen. n. sp., Cooleyella platera n. sp., and Amaradontus santuccii n. gen. n. sp.were found relatively commonly within the above sections while cf. Mesomodus sp., Novaculodus billingsleyi n. gen. n. sp., and Cooleyella fordi are only known from one or two teeth in total. The record of euselachian grade taxa is rather poor at Bear Gulch, with only a few undescribed forms being mentioned in reviews of the fauna (Lund et al., 2012, 2015). This shortage of data on the euselachian diversity at Bear Gulch should be short lived because new taxa are currently being studied (R. Lund and E. Grogan, personal communication, 2015-2016). There are no other late Serpukhovian records of euselachians in North America at present. Eurasian records of Serpukhovian/Bashkirian euselachians are known primarily from a few isolated teeth. The anachronistid neoselachian Ginteria fungiforma Duffin and Ivanov, 2008 was recorded from the Steshev Formation (early Serpukhovian) of the Moscow District, Russia (Duffin and Ivanov, 2008); the basal Euselachian Gissarodus flabellatus Ivanov, 2013 was recorded from the Khodzhir-Bulak Formation (late Serpukhovian-early Bashkirian) in the Gissar Mountains of south-eastern
Uzbekistan (Ivanov, 2013); and Protacrodus sp. was recorded from the Bashkirian borehole studies of the North Urals (Ivanov, 1999).

The temporal extension of Clairina.-The enigmatic taxon Clairina was previously only known from the Upper Devonian (Famennian) of Morocco, Poland, and Germany, as the single species, C. marocensis Derycke, 1992 (Ginter et al., 2010). However, the new occurrence of Clairina in the Surprise Canyon Formation extends this taxon by ca. $28 \mathrm{Myr}$ to the latest Mississippian. Although the two specimens are broken, the unworn condition of both specimens and the fact that they are separated by two stratigraphic intervals at the Bat Tower 2 type section rules out the possibility that these specimens are reworked from older sediments. The karst formation of the paleo-valleys of the Surprise Canyon Formation occured in the underlying Redwall Limestone, a Lower Mississippian formation, below which is the Middle Devonian Temple Butte Formation.

\section{The Late Mississippian/Early Pennsylvanian marine shark assemblages and their global relationship}

The small, however surprisingly diverse, sample of chondrichthyan taxa from the Surprise Canyon and Watahomigi formations of the Grand Canyon adds to the relatively few records of sharks from the Mississippian to Pennsylvanian transition during the middle Carboniferous. Below is a relative comparison with the currently known chondrichthyan assemblages for the latest Mississipian and Early Pennsylvanian:

Latest Mississippian (Serpukhovian).--In North America there are at least four marine fish assemblages from the Serpukhovian. Stahl and Cicimurri (2005) described a chondrichthyan assemblage from the Monteagle Limestone in northern Alabama, which consisted of isolated large teeth of at least fifteen taxa. The Surprise Canyon assemblage and the Monteagle Assemblage share the occurrence of the taxa Cladodus, Cochliodus, and Deltodus, but differ at the species level. At Monteagle, at least two species of Cladodus have been identified, "C." newmani? Tuomey, 1858 and "C." magnificus Tuomey, 1858 (now synonymized with Saivodus striatus, vide Duffin and Ginter, 2006); two species of Cochliodus, C. leidyi and C. cf C. vanhorni; and Deltodus sp. (Stahl and Cieimurri, 2005). The Fayetteville Formation of Arkansas has presently produced a small but significant collection of nearly articulated chondrichthyan specimens, many preserving a degree of three-dimensionality. Taxa described thus far include Carcharopsis wortheni Newberry and Worthen, 1866 (Lund and Mapes, 1984; Bronson et al., 2018), "Cobelodus" sp. (Maisey, 2007), and Ozarcus mapesae (Pradel et al., 2014). Of the taxa from the Fayetteville assemblage, only Ozarcus mapesae may have ties with the Surprise Canyon assemblage in the form of the indeterminate falcatid teeth. Although both the teeth of Ozarcus and the indeterminate taxa from the Surprise Canyon Formation are small, the teeth of Ozarcus have only been identified and described from three-dimensional segmentation data (Pradel, et al., 2014). This method presently does not show the fine 
details commonly used to describe chondrichthyan teeth, and drawing a relationship among the different taxa is at best broadly speculative and inconclusive.

The Manning Canyon Shale assemblage of central Utah has also preserved a small but well-preserved vertebrate fauna of either marine or brackish influence (Mickle, 2011). At present, isolated shark teeth (Miller, 1981), an acanthodian (Schultze, 1990), a microsaur (Caroll et al., 1991), and three actinopterygians (Mickle, 2011) have been described. Of the chondrichthyans, Miller (1981) described two isolated cladodont teeth, which he tentatively referred to Cladodus sp. based on their five-cusped structure, but as two separate taxa. The smaller of the two specimens (BYU 4370) has a welldeveloped basolabial depression, similar in structure to Glikmanius (Ginter et al., 2005). It is difficult to determine which species of Cladodus the larger of the two specimens (BYU 4369) (Miller, 1981) represents. However, the narrow proportions of the median and intermediate cusps in this specimen does eliminate $C$. marginatus from consideration. The Manning Canyon Shale assemblage is the closest geographic location to the Surprise Canyon assemblage because both locations were in close proximity to the paleoequator (Fig. 16). However, comparison between these two chondrichthyan assemblages is inconclusive at this time because the Manning Canyon Shale assemblage has only a small chondrichthyan component.

The Bear Gulch Limestone in Montana is perhaps the best-known locality not only in North America, but for the global record of fish for the Late Mississippian. Approximately seventy-five nominal genera have been identified (Lund et al., 2015), and of these seventy-five taxa, thirty-six are chondrichthyans (Lund et al., 2015). At the family level, the Surprise Canyon assemblage shares with the Bear Gulch assemblage at least seven familes (Thrinacodontidae, Stethacanthidae, Falcatidae, Ctenacanthidae, Gregoriidae, Debeeriidae, and Cochliodontidae). Both assemblages share at the order level the presence of the Petalodontiformes, Eugenodontiformes, Orodontiformes, and Helodontiformes, which, with the exception of the Petalodontiformes, are yet to be described in detail from Bear Gulch (Lund et al., 2014, 2015). However, the Surprise Canyon assemblage does differ significantly from the Bear Gulch assemblage in the presence of the xenacanthimorph Bransonella, the elasmobranch Clairina, members of the Protacrodontidae, and members of the Anachronistidae. There is an also a latitudinal difference between the two locations. The Bear Gulch assemblage was located near the $12^{\circ}$ North latitude, which influenced an arid seasonal deposition (Lund et al., 2012), whereas the

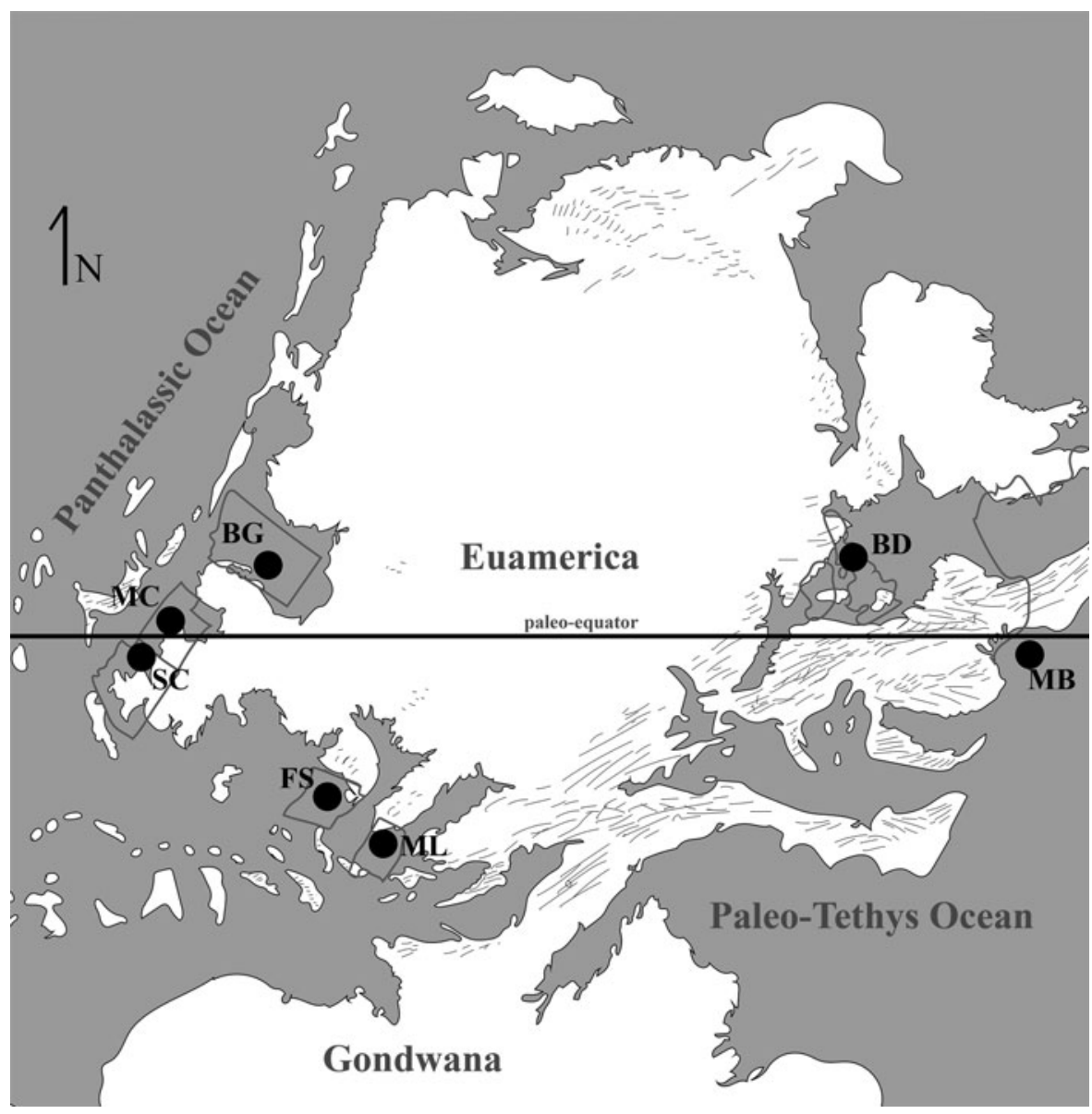

Figure 16. Paleogeography of the Latest Mississippian (Serpukhovian) of Euamerica and the primarily known marine fish assemblages. BD, Bearsden assemblage, Scotland; BG, Bear Gulch Limestone assemblage, Montana; FS, Fayetteville Shale assemblage, Arkansas; MB, Moscow Basin (Serpukhovian type section) assemblage, Russia; MC, Manning Canyon Shale assemblage, central Utah; ML, Monteagle Limestone, Alabama; SC, Surprise Canyon Formation assemblage, Grand Canyon, Arizona. 
Surprise Canyon assemblage was within a tropical equatorial zone with greater fluvial and estuarine depositional influences (Fig. 16).

The Eurasian marine record of Serpukhovian chondrichthyans is known primarily from tooth-taxon assemblages. The type section for the Serpukhovian is located in the Moscow Basin (Fig. 16), and contains chondrichthyan assemblages typical of the East European Platform (Duffin and Ivanov, 2008). Chondrichthyans known from the East European Platform include the anchronistid euselachians Ginteria fungiforma (Duffin and Ivanov, 2008), cf. Thrinacodus gracia (Ginter and Turner, 2010), and the xenacanthomorph Bransonella lingulata (Ivanov and Ginter, 1996; Hampe and Ivanov, 2007). Ivanov (1999) reported indeterminate "cladodont'grade teeth of symmoriforms and ctenacanths from the South Island of the Novaya Zemlya Archipelago and the Russian Arctic. The Bearsden and East Kilbride marine/nonmarine chondrichthyan assemblages of the Manse Burn Formation of Northern Scotland are at present the only Eurasian Serpukhovian localities that preserve articulated or disarticulated chondrichthyan endoskeletal material. Taxa such as the symmoriids Denaea sp., "Symmorium" sp., Gutturensis neilsoni Sequeira and Coates, 2000, and Akmonistion zangerli, the euselachian Tristychius arcuatus Agassiz, 1843, and the holocephalan Deltoptychius sp. have been recorded from both localities (Dick et al., 1986; Stahl, 1999; Sequeira and Coates, 2000; Coates and Sequeira, 2001). It can be argued that there is little published data to support a relationship between the Eurasian Serpukhovian chondrichthyans and the Surprise Canyon assemblage with the exception of the possible cf. Thrinacodus gracia (Ginter and Turner, 2010). Bransonella is represented on the East European Platform by $B$. lingulata, while $B$. nebraskensis is known from the Surprise Canyon assemblage.

Earliest Pennsylvanian (Bashkirian).--In Europe, the chondrichthyan record is composed of tooth-taxa assemblages. Ivanov (1999) reported on the teeth and dermal denticles of Protacrodus, symmoriids, ctenacanths, and other neoselachians from the North Urals, an isolated tooth plate of Lagarodus from the River Shar'yu of the Chernyshev Ridge, and stethacanthid and Denaea-like teeth, and neoselachian dermal denticles from the South Island of the Novaya Zemlya Archipelago. Ivanov (2013) also reported on a Late Serpukhovian-Early Bashkirian marine chondrichthyan assemblage from the Gissar Mountains of Uzbekistan. The taxa described here include the symmoriids Denaea cf. D. williamsi and Stethacanthulus decorus Ivanov, 1999, the euselachian Gissarodus flabellatus, and indeterminate dermal denticles (Ivanov, 2013). In North America, the best known Bashkirian fish assemblage is from the Joggins Formation of Nova Scotia. The chondrichthyans and other fishes identified here have been reported as representing a euryhaline assemblage (Carpenter et al., 2015). Chondrichthyans described from Joggins include Ctenacanthus sp., Orthacanthus cf. denticulatus Davis, 1880, an indeterminate xenacanth, and the chondrichthyan Ageleodus pectinatus Agassiz, 1843 (Carpenter et al., 2015). Additionally, a chondrichthyan assemblage from the the late Bashkirian Black Prince Limestone of the Swisshelm Mountains of southern Arizona includes xenacanths, cladodont-grade teeth, helodontids, and petalodonts (Johnson and Thayer, 2009). Of the xenacanths from the Black Prince Limestone, Bransonella was recorded from numerous specimens which Johnson and Thayer (2009) tentatively identified as B. ?nebraskensis, $B$. ?lingulata, $B$. sp. A, and $B$. sp. B, respectively. The $B$. ?lingulata specimen from the Black Prince Limestone, if valid, would be the earliest record of $B$. lingulata in North America. Presently, this record suggests the distribution of $B$. lingulata to North America occurred after the Serpukhovian. A Demoinesian record of B. lingulata is now recognized from the Buckhorn Asphalt Quarry in southern Oklahoma (Ivanov et al., 2017). The Watahomigi Formation of the Grand Canyon is at present the only known fully marine locality yielding chondrichthyans and includes Hokomata parva n. gen. n. sp. and Deltodus sp.

\section{Conclusions}

The chondrichthyan assemblage from the Latest Mississippian (Serpukhovian) Surprise Canyon Formation of the western Grand Canyon is remarkably diverse with a total of thirty-one taxa, identified from teeth and dermal elements. This assemblage best compares with the Bear Gulch Limestone assemblage from central Montana. The Surprise Canyon assemblage provides a range extension of the paraselachians Srianta and Heteropetalus, which previously were only known from the Bear Gulch Limestone assemblage. However, the Surprise Canyon assemblage differs from the Bear Gulch assemblage in its greater number of euselachian taxa and the presence of the xenacanthimorph Bransonella nebraskensis and the elasmobranch Clairina sp. The protacrodonts from the Surprise Canyon assemblage represent an ecological split from the generalized Protacrodus tooth model (Ginter et al., 2010), with the more durophagus dentition of Microklomax carrieae $\mathrm{n}$. gen. $\mathrm{n}$. sp. and the more hypocarnivorous dentition of Novaculodus billingsleyi $\mathrm{n}$. gen. n. sp. The anachronistid euselachians also show a greater diversity with the additions of Cooleyella platera n. sp. and Amaradontus santuccii n. gen. n. sp.

Following an overview of the Serpukhovian Euamerica marine chondrichthyan assemblages (Fig. 16), we tentatively suggest there may have been an eastern and western distinction between the Eurasian assemblages. All Eurasian and North American assemblages share taxa at the order, family, and in some cases, genus levels, but neither faunas show similarity at the species level. This suggests that after the closing of the Rheic Ocean during the early Carboniferous (Nance et al., 2012), many of these taxonomic groups were already in place. However, the closure of the Rheic Ocean provided the catalyst for these groups to further evolve in isolation from one another, resulting in the differences we see at the species level. The one exception to this tentative speciation model is the presence of Thrinacodus gracia from the Moscow Region of Russia. Ginter and Turner (2010) recognized two partial teeth, which they referred to cf. Thrinacodus gracia from a larger collection made by A. Ivanov in the Kalionovskie Vyelki Quarry near Moscow, Russia. The presence of these teeth in Eurasia suggests a connection between the western North American chondrichthyan assemblages while Eurasia was still present, or that the 
origin and distribution of T. gracia occurred earlier, before the closure of the Rheic Ocean.

The poor record of marine chondrichthyans of the Early Pennsylvanian Bashkirian is only slightly supplemented by the new record from the Watahomigi Formation in the western Grand Canyon. The presence of the new diplodoselachian xenacanth, Hokomata parva n. gen. n. sp., within the interval of the Watahomigi Formation indicates that some xenacanth taxa were capable of living in marine conditions. Most of the marine records of Bashkirian chondrichthyans are from Eurasia (Ivanov, 1999, 2013), while in North America the chondrichthyans are primarily euryhaline (Johnson and Thayer, 2009; Carpenter et al., 2015). The records of "Deltodus" by McKee (1982) from the Guano Cave, Parashant Canyon, and Separation Canyon stongly suggest additional chondrichthyan fossils could be found in the Watahomigi Formation of the western Grand Canyon and could expand the data for the Bashkirian chondrichthyan assemblages.

In conclusion, the specimens described here from the Surprise Canyon and Watahomigi formations of the western Grand Canyon most likely represent a small fraction of the fauna present during those depositional events. Unfortunately, these specimens do not fully illuminate the transition of chondrichthyan assemblages across the Mississippian/Pennsylvanian boundary. Further work, particularly with the Watahomigi Formation, could expand our knowledge of this transition.

\section{Acknowledgments}

We thank C. Brugger-Schorr for bringing the conodont residue material to our notice, which in turn inspired this project. Special thanks to J. Wittke for SEM imagery and A. Millhouse in the Paleobiology Department at the Smithsonian for her assistance in the collections and for specimen loans. We greatly appreciate assistance from D. and J. Gillette for helping us with collection information at the Museum of Northern Arizona. Conversations with and suggestions from A. Ivanov greatly improved this project. JPH particularly would like to thank his academic advisors, E. Grogan and R. Lund, for sharing their knowledge and data on chondrichthyans and the Bear Gulch Limestone during his tutelage at SJU. We thank our reviewers, S. Turner, A. Ivanov, and C. Underwood, for providing useful comments that helped to improve this manuscript.

\section{References}

Agassiz, L.J.R., 1843 (1833-1843), Recherches sur les poisons fossils: (Petitpierre), Neuchâtel et Soleure, v. 3, 390 p.

Agassiz, L., 1859, Notes on the collections of Lord Enniskillen and Sir Philip Egerton \& London notes, A: Ms. (unsigned), MCZ archives, Harvard University, Cambridge, Massachusetts, U.S.A., 14 sheets.

Behan, C., Walken, G., and Cuny, G., 2012, A Carboniferous chondrichthyan assemblage from residues within a Triassic karst system at Cromhall Quarry, Gloucestershire, England: Palaeontology, v. 55, p. 1245-1263.

Berg, L.S., 1937, A classification of fish-like vertebrates: Bulletin of the Academy of Sciences of the URSS, Biology Series, no. 4, p. 1277-1280.

Beus, S.S., 1985, Late Mississippian fossil communities in the Surprise Canyon Formation, an estuarine sequence in Grand Canyon, Arizona: Abstracts of the Symposium on south western Geology and Paleontology, Museum of Northern Arizona, Flagstaff, p. 1.

Beus, S.S., 1986, Biostratigraphy of the Surprise Canyon Formation (Latest Mississippian and Earliest Pennsylvanian) in western Grand Canyon: Geological Society of America Abstracts with Programs, v. 18, p. 341.
Beus, S.S., 1999, Chapter E: megafossil paleontology, in Billingsley, G.H., and Beus, S.S., eds., Geology of the Surprise Canyon Formation of the Grand Canyon, Arizona: Museum of Northern Arizona Bulletin, no. 61, p. 69-96.

Beus, S.S., and Martin, H., 1999, Chapter G: age and correlation of the Surprise Canyon Formation, in Billingsley, G.H., and Beus, S.S. eds., Geology of the Surprise Canyon Formation of the Grand Canyon, Arizona: Museum of Northern Arizona Bulletin, no. 61, p. 117-120.

Bigelow, H.B., and Schroeder, W.C., 1953. Sharks, sawfishes, guitarfishes, skates and rays. Chimaeroids, in Tee-Van, J., et al., eds., Fishes of the Western North Atlantic. Part 2: Sears Foundation for Marine Research, Yale University, New Haven, p. 1-514.

Billingsley, G.H., 1978, A synopsis of the stratigraphy in the Western Grand Canyon, Arizona: Museum of Northern Arizona Press Research Paper no. 16, p. 7-9.

Billingsley, G.H., and Beus, S.S., 1985, The Surprise Canyon Formation-an upper Mississippian and Lower Pennsylvanian (?) rock unit in the Grand Canyon, Arizona: Stratigraphic Notes, 1984. U. S. Geological Survey Bulletin, no. 1605-A, p. 27-33.

Billingsley, G.H., and Beus, S.S., 1999a, Chapter A: overview, in Billingsley, G.H., and Beus, S.S., eds., Geology of the Surprise Canyon Formation of the Grand Canyon, Arizona: Museum of Northern Arizona Bulletin, no. 61, p. 1-8.

Billingsley, G.H., and Beus, S.S., 1999b, Appendices 1-3, in Billingsley, G.H., and Beus, S.S., eds., Geology of the Surprise Canyon Formation of the Grand Canyon, Arizona: Museum of Northern Arizona Bulletin, no. 61, p. $155-244$.

Billingsley, G.H., and McKee, E.D., 1982, Pre-Supai buried valleys, in McKee, E.D., ed., The Supai Group of Grand Canyon: U. S. Geological Survey Professional Paper 1173, p. 137-153.

Billingsley, G.H., Beus, S.S., and Grover, P., 1999, Chapter B: stratigraphy of the Surprise Canyon Formation, in Billingsley, G.H., and Beus, S.S., eds., Geology of the Surprise Canyon Formation of the Grand Canyon, Arizona: Museum of Northern Arizona Bulletin, no. 61, p. 9-17.

Binney, E.W., 1841, On the fossil fishes of the Pendleton Coal Field: Transactions of the Geological Society Manchester, v. 1840, p. 153-178.

Bonaparte, C.L.J.L., 1838, Iconografia della fauna italic per le quarto classi degli animali vertebrati: Tomo III, Pesci: (Slviucci) Roma, Salviucci, 266 p.

Bonaparte, C.L.J.L., 1832-1841, A new systematic arrangement of vertebrate animals: Transactions of the Linnean Society of London, v. 18, p. 247-304.

Bronson, A.W., Mapes, R.H., and Maisey, J.G., 2018, Chondrocranial morphology of Carcharopsis wortheni (Chondrichthyes, Euselachii incertae sedis) based on new material from the Fayetteville Shale (Upper Mississippian, Middle Chesterian): Papers in Paleontology, doi: 10.1002/spp2.1110, p. $1-14$.

Capetta, H., Duffin, C.J., and Zidek, J., 1993, Chondrichthyes, in Benton, M.J., ed., The Fossil Record 2, London, Chapman and Hall, p. 593-609.

Carpenter, D.K., Falcon-Lang, H.I., Benton, M.J., and Grey, M., 2015, Early Pennsylvanian (Langsettian) fish assemblages from the Joggins Formation, Canada, and their implications for palaeoecology and palaeogeography: Palaeontology v. 58, p. 661-690.

Carrol, R.L., Bybee, P., and Tidwell, W.D., 1991, The oldest microsaur (Amphibia): Journal of Paleontology, v. 65, p. 314-322.

Coates, M.I., and Gess, R.W., 2007, A new reconstruction of Onychoselache traquairi, comments on early chondrichthyan pectoral girdles and hybodontiform phyogeny: Palaeontology v. 50, p. 1421-1446.

Coates, M.I., and Sequeira, S.E.K., 2001, A new stethacanthid chondrichthyan from the lower Carboniferous of Bearsden, Scotland: Journal of Vertebrate Paleontology, v. 21, p. 438-459.

Compagno, L.J.V., 1977, Phyletic relationships of living sharks and rays: American Zoologist, v. 17, p. 303-322.

Croneis, C.G., 1927, Sharks from the Fayetteville Formation: Pan-American Geologist, v. 47, p. 41-46.

Davis, J.W., 1880, On the genus Pleuracanthus, AGASS., including Orthacanthus, AGASS., and GOLDF., Diplodus, AGASS., and Xenacanthus, BEYR: Quarterly Journal of the Geological Society of London, v. 36, p. 321-336.

Davis, J.W., 1892, On the fossil fish-remains of the coal measures of the British Islands: Science Transactions of the Royal Dublin Society, v. 2, p. 703-748.

Dean, B., 1909, Studies on fossil fishes (sharks, chimaeroids, and arthrodires): Memoirs of the American Museum of Natural History, v. 9, p. 211-287.

De Koninck, L.G., 1844, Description des animaux fossiles qui se trouvent dans le terrain Carbonifère de Belgique: Liège, H. Dessain, 716 p.

De Koninck, L.G., 1878, Faune du calcaire carbonifère de la Belgique. Premièr partie, poisons et genre nautile: Annales du Royale Musée d'Histoire Naturelle de Belgique, v. 2, p. 9-76.

Derycke, C., 1992, Microrestes de sélachiens et autres Vertébrés du Dévonien supérieur du Maroc: Bulletin du Muséum National d'Histoire Naturelle, v. 14 , p. $15-61$. 
Derycke-Khatir, C., 2005, Microrestes de Vertébrés du Paléozöique Supérieur de la Manche au Rhin: Société Geologique du Nord Publication, v. 33, p. 1-363.

Dick, J.R.F., 1978, On the Carboniferous shark Tristychus arcuatus Agassiz from Scotland: Transactions of the Royal Society of Edinburgh, v. 70, p. 63-90.

Dick, J.R.F., 1981, Diplodoselache woodi gen. et sp. nov., an early Carboniferous shark from the Midland Valley of Scotland: Transactions of the Royal Society of Edinburgh, v. 72, p. 99-113.

Dick, J.R., 1998, Sphenacanthus, a Palaeozoic freshwater shark: Zoological Journal of the Linnean Society, v. 122, p. 9-25.

Dick, J.R., Coates, M.I., and Rolfe, W.D.I., 1986, Fossil sharks: Geology Today v. 2 , p. $82-84$

Duffin, C.J., and Ginter, M., 2006, Comments on the selachian genus Cladodus Agassiz, 1843: Journal of Vertebrate Paleontology, v. 26, p. 253-266.

Duffin, C.J., and Ivanov, A., 2008, New chondrichthyan teeth from the early Carboniferous of Britain and Russia: Acta Geologica Polonica v. 58, p. 191-197.

Duffin, C.J., and Ward, D.J., 1983, Neoselachian shark teeth from the lower Carboniferous of Britain and the lower Permian of the U.S.A.: Palaeontology, v. 26, p. 93-110.

Duffin, C.J., Richter, M., and Neis, P.A., 1996, Shark remains from the late Carboniferous of the Amazon Basin, Brazil: Neues Jahrbuch für Geologie un Paläontologie, Monashefte, v. 4, p. 232-256.

Duncan, M., 2003, Early Carboniferous condrichthyan Thrinacodus from Ireland, and a reconstruction of jaw apparatus: Acta Palaeontologica Polonica, v. 48 , p. $113-122$

Elliott, D.K., and Hodnett, J.-P.M., 2013, A new species of Bransonella (Chondrichthyes, Xenacanthimorpha, Bransonelliformes) from the middle Permian Kaibab Formation of northern Arizona: Journal of Paleontology, v. 87 , p. $1136-1142$.

Elliott, D.K., Irmis, R.B., Hansen, M.C., and Olson, T.J., 2004, Chondrichthyans from the Pennsylvanian (Desmoinesian) Naco Formation of central Arizona: Journal of Vertebrate Paleontology, v. 24, p. 268-280.

Friedman, M., 2015, The early evolution of ray-finned fishes: Palaeontology, v. 58 , p. $213-228$

Friedman, M., and Sallan, L.C., 2012, Five hundred million years of extinction and recovery: a Phanerozoic survey of large-scale diversity patterns in fishes: Palaeontology, v. 55, p. 707-742.

Ginter, M., 1995, Ichthyoliths and Late Devonian events in Poland and Germany: Ichthyolith Issues, Special Publication, v. 1, p. 23-30.

Ginter, M., 1999, Famennian-Tournaisian chondrichthyan microremains from the eastern Thuringian Slate Mountains: Abhandlungen Bericht der Naturkundlichen, Magdeburg, v. 21, p. 25-47.

Ginter, M., 2002, Taxonomic notes on "Phoebodus heslerorum" and Symmorium reniforme (Chondrichthyes, Elasmobranchii): Acta Palaeontologica Polonica, v. 47, p. 547-555.

Ginter, M., and Hansen, M., 2010, Teeth of the cladodont shark Denaea from the Carboniferous of central North America, in Nowakowski, D., ed. Morphology and Systematics of Fossil Vertebrates: Warsaw, DN Publisher, p. 29-44.

Ginter, M., and Sun, Y., 2007, Chondrichthyan remains from the lower Carboniferous of Muhua, southern China: Acta Palaeontologica Polonica, v. 52, p. 705-727.

Ginter, M., and Turner, S., 2010, The middle Paleozoic selachian genus Thrinacodus: Journal of Vertebrate Paleontology v. 30, p. 1666-1672.

Ginter, M., Hairapetian, V., and Klug, C., 2002, Famennian chondrichthyans from the shelves of North Gondwana: Acta Geologica Polonica, v. 52, p. 169-215.

Ginter, M., Ivanov, A., and Lebedev, O., 2005, The revision of "Cladodus" occidentalis, a late Palaeozoic ctenacanthiform shark: Acta Palaeontologica Polonica, v. 50, p. 623-631.

Ginter, M., Hampe, O., and Duffin, C.J., 2010, Chondrichthyes. Paleozoic Elasmobranchii: teeth, in Schultze, H.-P., ed., Handbook of Paleoichthyology, v. 3D: München, Friedrich Pfeil, p. 168.

Ginter, M., Duffin, C.J., Dean, M.T., and Korn, D., 2015, Late Visean pelagic chondrichthyans from northern Europe: Acta Palaeontologica Polonica, v. 60, p. 899-922.

Glikman, L.S., 1964, [Subclass Elasmobranchii. Sharks.], in Obruchev, D.V., ed., Osnovy Paleontologii. XI. Beschelustnye, ryby, (Nauka), Moscow, p. $196-237$.

Gordon, M., Jr., 1982, Biostratigraphy of the Watahomigi Formation, in McKee, E.D., ed., The Supai Group of Grand Canyon: U. S. Geological Survey Professional Paper 1173, p. 113-137.

Grogan, E.D., and Lund, R., 2000, Debeerius ellefseni (fam. nov., gen. nov., spec. nov.), an autodiastylic chondrichthyan from the Missippian Bear Gulch Limestone of Montana (USA), the relationship of the Chondrichthyes, and comments on gnathostome evolution: Journal of Morphology, v. 243 , p. $219-245$
Grogan, E.D., and Lund, R., 2008, A basal elasmobranch, Thrinacoselache gracia n. gen. et sp. (Thrinacodontidae, new family) from the Bear Gulch Limestone, Serpukhovian of Montana, USA: Journal of Vertebrate Paleontology, v. 28 , p. $970-988$

Grogan, E.D., Lund, R., and Fath, M., 2014, A new petalodont chondrichthyan from the Bear Gulch Limestone of Montana, USA, with reassessment of Netsepoye hawesi and comments on the morphology of holomorphic petalodonts: Palaeontological Journal, v. 48, p. 1003-1014.

Gross, W., 1938, Das Kopfskelett von Cladodus wildungensis Jaekel. 2. Tei; Der Kieferbogen. Anhang; Protacrodus vetustus Jaekel: Senckenbergiana, v. 20 , p. $123-145$

Grover, P.W., 1989, Stratigraphy and Depositional Environment of the Surprise Canyon Formation, an Upper Mississippian Carbonate-Clastic Estuarine Deposit, Grand Canyon, Arizona [MS thesis]: Flagstaff, Northern Arizona University, $303 \mathrm{p}$.

Gunnell, F.M., 1933, Conodonts and fish remains from the Cherokee, Kansas City, and Wabaunsee groups of Missouri and Kansas: Journal of Paleontology, v. 7, p. 261-297.

Hampe, O., and Heidtke, U.H.J., 1997, Hagenoselache sippeli n. gen. n. sp., ein früher xenacanthider Elasmobranchier aus dem Oberkarbon (Namurium B) von Hagen-Vorhalle (NW-Sauerland/Deutschland): Geologie und Paläontologie in Westfalen, v. 47, p. 5-42.

Hampe, O., and Ivanov, A., 2007, Bransonelliformes-a new order of Xenacanthimorpha (Chondrichthyes, Elasmobranchii): Fossil Record, v. 10, p. $190-194$.

Hansen, M.C., 1986, Microscopic chondrichthyan remains from Pennsylvanian marine rocks of Ohio and adjacent areas [Ph.D. dissertation]: Columbus, $\mathrm{OH}$, Ohio State University, $536 \mathrm{p}$.

Hansen, M.C., 1996, Phylum Chordata-Vertebrate Fossils, in Feldmann, R.M., and Hackathorn, M., eds., Fossils of Ohio: Ohio Division of Geological Survey, Bulletin, no. 70, p. 288-369.

Harlton, B.H., 1933, Micropaleontology of the Pennyslvanian Johns Valley Shale of the Ouachita Mountains, Oklahoma, and its relationship to the Mississippian Caney Shale: Journal of Paleontology, v. 7, p. 3-29.

Hay, O.P., 1902, Description of a new species of Cladodus (C.formosus) from the Devonian of Colorado: American Geologist, v. 30, p. 373-374.

Hodnett, J.-P.M., and Lucas, S.G., 2015, Paleozoic Fishes of New Mexico, in Lucas, S.G., and Sullivan, R.M, eds., Fossil Vertebrates in New Mexico: New Mexico Museum of Natural History and Science Bulletin, v. 68, p. $51-63$

Hodnett, J.-P.M., Elliott, D.K., Olson, T.J., and Wittke, J.H., 2012. Ctenacanthiform sharks from the Permian Kaibab Formation, northern Arizona: Historical Biology, v. 24, p. 381-395.

Huxley, T., 1880, A Manual of the Anatomy of Vertebrated Animals: New York, D. Appleton \& Co., 431 p.

Irmis, R.B., and Elliott, D.K., 2006, Taphonomy of a middle Pennsylvanian marine vertebrate assemblage and an actualistic model for marine abrasion of teeth: Palaios, v. 21, p. 466-479.

Itano, W.M., Hauk, K.J., and Lockley, M.J., 2003, Ctenacanthus and other chondrichthyan spines and denticles from the Minturn Formation (Pennsylvanian) of Colorado: Journal of Paleontology, v. 77, p. 524-535.

Ivanov, A. O., 1996, The Early Carboniferous chondrichthyans of the South Urals, Russia: Geological Society, London, Special Publications, v. 107, p. $417-425$.

Ivanov, A.O., 1999, Late Devonian-early Permian chondrichthyans of the Russian Arctic: Acta Geologica Polonica, v. 49, p. 267-285.

Ivanov, A.O., 2005, Early Permian chondrichthyans of the middle and south Urals: Revista Brasileira de Paleontologia, v. 8, p. 127-138.

Ivanov, A.O., 2011, [Permian anachronistid sharks of the East European Platform and Urals, in Russian], in Pozvonochnye Paleozoya i Mesozoya Evrazii: evolutsiya, smena coobshchestv, tafonomiya i paleobiogeografiya. Materialy konferentsii, posvyashchennoy 80-letiyu co dnya rozhdeniya Vitaliya Georgievicha Ocheva (1931-2004) (6 December, 2011, PIN RAN, Moskva). Moskva, Paleontologicheskiy Insititut, RAN, 63 p. (in Russian).

Ivanov, A. O., 2013, Chondrichthyans from the early/late Carboniferous boundary beds of the Gissar Mountains, Uzbekistan, in Lucas, S.G., DiMichelle, W.A., Barrick, J.E., Schneider, J.W., and Spielmann, J.A., eds., The Carboniferous-Permian Transition: New Mexico Museum of Natural History and Science, Bulletin, v. 60, p. 143-151.

Ivanov, A. O., and Ginter, M., 1996, Early Carboniferous xenacanthids (Chondrichthyes) from eastern Europe: Bulletin de la Societé Géologique de France, v. 167, p. 651-656.

Ivanov, A. O., Liapin, V.R., and Bolshijanov, I.P., 2014, The Early Carboniferous neoselachian sharks of the Moscow syneclise: palaeontology in the museum practice: Collection of the Scientific Articles: Moscow, MediaGrand, 174 p. [in Russian]

Ivanov, A.O., Nestell, M.K., and Nestell, G.P., 2015, Middle Permian fish microremains from the early Capitanian of the Guadalupe Mountains, West Texas, USA: Micropaleontology, v. 61. p. 301-312. 
Ivanov, A.O., Seuss, B., and Nützel, A., 2017, The fish assemblage from the Pennsylvanian Buckhorn Asphalt Quarry Lagerstätte (Oklahoma, USA): Paläontologische Zeitschrift, DOI 10.1007/s12542-017-0361-9

Jaekel, O., 1925, Das Mundskelett der Wirbeltiere: Gegenbaurs Morphologisches Jahrbuch, v. 55, p. 402-409.

Johnson, G.D., 1984, A new species of Xenacanthodii (Chondrichthyes, Elasmobranchii) from the late Pennsylvanian of Nebraska, $n$ Mengal, R.M., ed., Papers in Vertebrate Paleontology Honoring Robert Warren Wilison: Carnegie Museum of Natural History Special Publication, v. 9, p. 178-186.

Johnson, G.D., and Thayer, D.W., 2009, Early Pennsylvanian xenacanth chondrichthyans from the Swisshelm Mountains, Arizona, USA: Acta Palaeontologica Polonica, v. 54, p. 649-668.

Lockley, M.G., 1984, Pennsylvanian predators: a preliminary report on some Carboniferous shark remains from Colorado: University of Colorado at Denver Geology Department Magazine, v. 3, p. 18-22.

Long, J.A., 1990, Late Devonian chondrichthyans and other microvertebrate remains from northern Thailand: Journal of Vertebrate Paleontology, v. 10 , p. $59-71$.

Lund, R., 1974, Stethacanthus altonensis (Elasmobranchii) from the Bear Gulch Limestone of Montana: Annals of the Carnegie Museum, v. 45, p. 161-178.

Lund, R., 1977, A new petalodont (Chondrichthyes, Bradyodonti) from the Upper Mississippian of Montana: Annals of the Carnegie Museum, v. 46, p. $129-155$.

Lund, R., 1983, On a dentition of Polyrhizodus (Chondrichthyes, Petalodontiformes) from the Namurian Bear Gulch Limestone of Montana: Journal of Vertebrate Paleontology, v. 3, p. 1-6.

Lund, R., 1984, On the spines of the Stethacanthidae (Chondrichthyes), with a description of a new genus from the Mississippian Bear Gulch Limestone: Geobios, v. 17, p. 281-295.

Lund, R., 1985a, Stethacanthid elasmobranch remains from the Bear Gulch Limestone (Namurian E2b) of Montana: American Museum Novitates, no. 2828 , p. $1-24$.

Lund, R., 1985b, The morphology of Falcatus falcatus (St. John and Worthen), a Mississippian stethacanthid chondrichthyan from the Bear Gulch Limestone of Montana: Journal of Vertebrate Paleontology, v. 5, p. 1-19.

Lund, R., 1986, On Damocles serratus, nov. gen. et sp. (Elasmobranchii: Cladodontida) from the Upper Mississippian Bear Gulch Limestone of Montana: Journal of Vertebrate Paleontology, v. 6, p. 12-19.

Lund, R., 1989, New petalodonts (Chondrichthyes) from the Upper Mississippian Bear Gulch Limestone (Namurian $\mathrm{E}_{2} \mathrm{~b}$ ) of Montana: Journal of Vertebrate Paleontology, v. 9, p. 350-368.

Lund, R., and Grogan, E.D., 1997, Relationships of the Chimaeriformes and the basal radiation of the Chondrichthyes: Reviews in Fish Biology and Fisheries, v. 7, p. 65-123.

Lund, R., and Grogan, E.D., 2004, Five new euchondrocephalan Chondrichthyes from the Bear Gulch Limestone (Serphukovian, Namurian E2b) of Montana, USA, in Arratia, G., Wilson, M.V.H., and Cloutier, R., eds., Recent Advances in the Origin and Early Radiation of Vertebrates: Honoring Hans-Peter Schultze: Munchen, Friedrich Pfeil, p. 505-531.

Lund, R., and Mapes, R. H., 1984, Carcharopsis wortheni from the Fayettevile Formation (Mississippian) of Arkansas: Journal of Paleontology, v. 58, p. 709-717.

Lund, R., Garton, E.R., and Weishampel, D.B., 1979, Fossil vertebrates of the Pennsylvanian system of West Virginia, in Englund, K.J., ed., Proposed Pennsylvanian System Stratotype, Virginia and West Virginia: AGI Selected Guidebook Series 1, p. 105-107.

Lund, R., Greenfest-Allen, E., and Grogan, E.D., 2012, Habitat and diversity of the Bear Gulch fish: life in a 318 million year old marine Mississippian bay: Palaeogeography, Palaeoclimatology, Palaeoecology, v. 342-343, p. 1-16.

Lund, R., Grogan, E.D., and Fath, M., 2014, On the relationships of the Petalodontiformes (Chondrichthyes): Palaeontological Journal v. 48, p. 10151029.

Lund, R., Greenfest-Allen, E., and Grogan, E.D., 2015, Ecomorphology of the Mississippian fishes of the Bear Gulch Limestone (Heath Formation, Montana, USA): Environmental Biology of Fish, v. 98, p. 739-754.

Maisey, J.G., 1975, The interrelationships of phalacanthous selachians: Neues Jahrbuch für Geologie und Paläontologie, Monatsh, v. 9, p. 563-567.

Maisey, J.G., 1982a, The anatomy and interrelationships of Mesozoic hybodont sharks: American Museum Novitates, no. 2724, p. 1-17.

Maisey, J.G., 1982b, Studies on the Paleozoic selachian genus Ctenacanthus Agassiz. No. 2. Bythiacanthus St. John and Worthen, Amelacanthus, new genus, Eunemacanthus St. John and Worthen, Sphenacanthus Agassiz, and Wodnika Munster: American Museum Novitates, no. 2722, p. 1-24.

Maisey, J.G., 1983, Some Pennsylvanian chondrichthyan spines from Nebraska: Transactions of the Nebraska Academy of Sciences, v. 11, p. 81-84.

Maisey, J.G., 1989, Hamiltonichthys mapesi, g. \& sp. nov. (Chondrichthyes; Elasmobranchii), from the Upper Pennsylvanian of Kansas: American Museum Novitates, no. 2931, p. 1-42.
Maisey, J.G., 2007, The braincase in Paleozoic symmoriiform and cladoselachian sharks: Bulletin of the American Museum of Natural History, no. 307, p. 1-122

Martin, H., 1992, Conodont biostratigraphy and paleoenvironment of the Surprise Canyon Formation (Late Mississippian) Grand Canyon Arizona [MS thesis]: Flagstaff, Northern Arizona University, Arizona, 298 p.

Martin, H., and Barrick, J.E., 1999, Chapter F: conodont biostratigraphy, in Billingsley, G.H., and Beus, S.S., eds., Geology of the Surprise Canyon Formation of the Grand Canyon, Arizona: Museum of Northern Arizona Bulletin, v. 61, p. 97-116.

McCoy, F., 1855, A systematic description of the British Paleozoic fossils in the Geological Museum of the University of Cambridge: London, John W. Parker and Sons, $661 \mathrm{p}$.

McKee, E.D., 1982. The Supai Group of Grand Canyon: U.S. Geological Survey Professional Paper, v. 1173, 504 p.

McKee, E.D., and Gutschick, R.C., 1969, History of the Redwall Limestone: Geological Society of America Memoir 114, 726 p.

Mickle, K.E., 2011, The early actinopterygian fauna of the Manning Canyon Shale Formation (Upper Mississippian, Lower Pennsylvanian) of Utah, U.S.A.: Journal of Vertebrate Paleontology, v. 31, p. 962-980.

Miller, W.E., 1981, Cladodont shark teeth from Utah: Journal of Paleontology, v 55, p. 894-895.

Morris, J., and Roberts, G.E., 1862, On the Carboniferous Limestone of Oreton and Farlow, Clee Hills, Shropshire: Quarterly Journal of the Geological Society of London, v. 18, p. 94-106.

Moy-Thomas, J.A., 1936, The structure and affinities of the fossil elasmobranch fishes from the lower Carboniferous rocks of Glencartholm, Eskdale: Proceedings of the Zoological Society of London, 1936, p. 761-788.

Nance, R. D., Gutierrez-Alonso, G., Keppie, J.D., Linnemann, U., Murphy, J.B. Quesada, C., Strachan, R.A., and Woodcock, N.H., 2012, A brief history of the Rheic Ocean: Geoscience Frontiers, v. 3, p. 125-135.

Nelson, J.S., 1976. Fishes of the World, v. 15: New York, Wiley \& Sons, $416 \mathrm{p}$ Newberry, J.S., 1879, Letter to Prof. John Collett, describing a collection of remains of fossil fishes collected in Indiana: Reports of the State Geologist of Indiana for the years $1876,1877,1878,1879$, p. 341-349.

Newberry, J.S., and Worthen, A.H., 1866, Descriptions of new species of Vertebrates, mainly from the Subcarboniferous limestone and Coal Measures of Illinois: Geological Survey of Illinois, v. 2, p. 9-134.

Newberry, J.S., and Worthen, A.H., 1870, Descriptions of fossil vertebrates: Geological Survey of Illinois, v. 4, p. 343-374.

Obruchev, D.V., 1953, Studies on edestids and the works of A. P. Karpinski: U.S.S.R. Academy of Sciences, Works of the Palaeontological Institute, v. 45 , p. $1-86$.

Owen, R., 1867, On the dental characters of genera and species, chiefly of fishes, from the Low Main Seam and shales of coal, Northumberland: Transactions of the Odontological Society of Great Britain, v. 5, p. 323-392.

Patterson, C., 1965, The phylogeny of the chimaeroids: Philosophical Transactions of the Royal Society of London (B), v. 249, p. 101-219.

Pradel, A., Maisey, J.G., Tafforeau, P., Mapes, R.H., and Mallatt, J., 2014, A Palaeozoic shark with osteichthyan-like branchial arches: Nature, v. 509, p. $608-611$.

Pruvost, P., 1919, Comparaison entre le terrain houiller du nord de la France et celui de la Grande-Bretagne, d'après la succession des faunes: Comptesrendus hebdomadaires des séances de l'Académie des sciences, Paris, v. 168, p. $782-785$

Pruvost, P., 1922, Description de Denaea fournieri, sélacien nouveau du Marbre noir de Denée, in Fournier, G., and Pruvost, P., Décoverte d'un poisson nouveau dans le marbre noir de Denée: Bulletin Academie Royal de Belgique, Classe des Sciences, v. 5, p. 213-218.

Racey, J.S., 1974, Conodont Biostratigraphy of the Redwall Limestone in Eastcentral Arizona [MS Thesis]: Tempe, AZ, Arizona State University, 200 p.

Sallan, L.C., 2014, Major issues in the origin of ray-finned fish (Actinopterygii) biodiversity: Biological Reviews, v. 89, p. 950-971.

Sando, W.J., 1969, Corals, in McKee, E.D., and Gutschick, R.C., eds., History of the Redwall Limestone: Geological Society of America Memoir 114, p. 257-344.

Schultze, H.-P., 1990, A new acanthodian from the Pennsylvanian of Utah, U.S.A, and the distribution of otoliths in gnathostomes: Journal of Vertebrate Paleontology, v. 10, p. 49-58.

Sequira, S.E.K., and Coates, M.I., 2000, Reassessment of 'Cladodus' neilsoni Traquair: a primitive shark from the Lower Carboniferous of East Kilbride, Scotland: Palaeontology, v. 43, p. 153-172.

Skipp, B., 1969, Foraminifera, in McKee, E.D., and Gutschick, R.C., eds., History of the Redwall Limestone: Geological Society of America Memoir 114, p. 173-256.

Smith, R., Martill, D.M., and Duffin, C., 2017, The shark-beds of the Eyam Limestone Formation (Lower Carboniferous), Visean of Steeplehouse Quarry, Wirksworth, Derbyshire, UK: Proccedings of the Geologists' Association, v. 128 , p. 374-400. 
Stahl, B., 1999, Chondrichthyes III. Holocephali, in Schultze, H.-P., ed., Handbook of Paleoichthyology, v. 4: München, Friedrich Pfeil, p. 1-164.

Stahl, B., and Cicimurri, D.J., 2005, Late Mississippian (Chesterian) chondrichthyans from the Monteagle Limestone of northern Alabama: Paludicola, v. 5, p. 1-14.

Stahl, B., and Hansen, M.C., 2000, Dentition of Deltodus angularis (Holocephali, Cochliodontidae) inferred from associated tooth plates: Copeia, v. 4, p. 1090-1096.

St. John, O., and Worthen, A.H., 1875, Description of fossil fishes: Geological Survey of Illinois, v. 6, Geology and Paleontology, Part II, Paleontology of Illinois, Section I, Descriptions of fossil fishes, p. 245-488.

Thayer, D.W., 1985, New Pennsylvanian lepospondyl amphibians from the Swisshelm Mountains, Arizona: Journal of Paleontology, v. 59, p. 684-700.

Traquair, R.H., 1884, Description of a fossil shark (Ctenacanthus costellatus) from the Lower Carboniferous rocks of Eskdale, Dumfrieshire: Geological Magazine, v. 3, p. 3-8.

Traquair, R.H., 1885, On a specimen of Psephodus magnus from the Carboniferous Limestone of East Kilbride, Lanarkshire: Geological Magazine, v. 2, p. 338-344.

Trautschold, H., 1879, Die Kalkbrüche von Mjatschkowa. Eine Monographie des oberen Bergkalks, Schluss: Nouveaux mémoires de la Société impériale des naturalistes de Moscou, v. 14, p. 3-82.

Tuomey, M., 1858, Descriptions and figures of Ctenacanthus elegans, Cladodus newmani, C. magnificus, in Mallett, J.W., ed., Second biennial report of the geology of Alabama: Montgomery, AL, p. 36-39.
Turner, S., 1982, Middle Paleozoic elasmobranch remains from Australia: Journal of Vertebrate Paleontology, v. 2, p. 117-131.

Turner, S., 1983, Taxonomic note on Harpago: Journal of Vertebrate Paleontology, v. 3, p. 38.

Turner, S., and Burrow, C.J., 2011, A lower Carboniferous xenacanthiform shark from Australia: Journal of Vertebrate Paleontology, v. 31, p. 241-257.

Tway, L.E., 1982, Geologic applications of the late Pennsylvanian ichthyoliths from the midcontinent region [Ph.D. dissertation]: Norman, OK, University of Oklahoma, $376 \mathrm{p}$.

Ward, J., 1875, On the organic remains of the Coal-Measures of north Staffordshire, their range and distribution, with a catalogue of the fossils and their mode of occurrence: Transactions of the North Staffordshire Field Club, 1875 , p. 589-594.

Zangerl, R., 1981, Chondrichthyes I. Paleozoic Elasmobranchii, in Schultze, H.-P., ed., Handbook of Paleoichthyology 3A: Stuttgart, New York, Gustav Fischer, $115 \mathrm{p}$.

Zangerl, R., 1990, Two new stethacanthid sharks (Stethacanthidae, Symmoriida) from the Pennsylvanian of Indiana, U.S.A.: Palaeontographica A, v. 213, p. 115-141.

Zidek, J., 1993, A large stethacanthid shark (Elasmobranchii, Symmoriida) from the Mississippian of Oklahoma: Oklahoma Geology Notes, v. 53, p. 4-15.

Accepted: 13 August 2018 